\title{
Total Synthesis of (+)-Amphidinolide A. Assembly of the Fragments
}

Barry M. Trost,* Stephen T. Wrobleski, John D. Chisholm, Paul E. Harrington, and Michael Jung

Department of Chemistry, Stanford University, Stanford, California 94305-5080

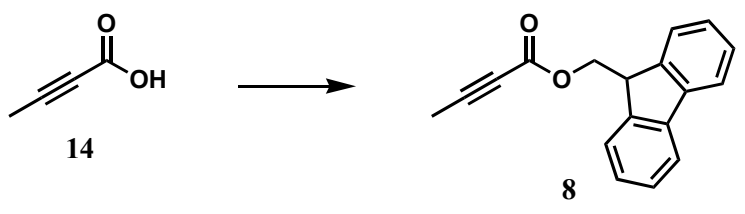

To a solution of acid 14 (2.202 g, $26.2 \mathrm{mmol})$ and 9-fluorenylmethanol (5.164 g, 26.3 $\mathrm{mmol})$ in benzene $(60 \mathrm{~mL})$ was added CSA $(600 \mathrm{mg}, 2.58 \mathrm{mmol})$. The reaction mixture was heated to reflux in a Dean-Stark trap. After $24 \mathrm{~h}$, the reaction mixture was diluted with ether, washed with saturated $\mathrm{NaHCO}_{3}(1 \mathrm{x})$ and brine $(1 \mathrm{x})$, dried over $\mathrm{MgSO}_{4}$, and concentrated. Purification by flash column chromatography on silica gel (10\% to $15 \%$ to $20 \%$ EtOAc in petroleum ether) gave ester $8(6.627 \mathrm{~g}, 96 \%)$ as a low melting white solid: $R_{f}=0.55(30 \%$ $\mathrm{Et}_{2} \mathrm{O} / 70 \%$ petroleum ether); IR (film from $\mathrm{CH}_{2} \mathrm{Cl}_{2}$ ) 3058, 2958, 2243, $1709 \mathrm{~cm}^{-1}$; ${ }^{1} \mathrm{H}$ NMR (300

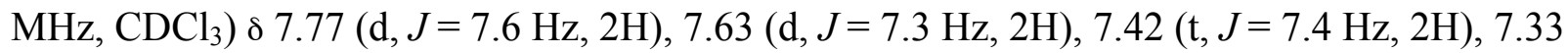
$(\mathrm{t}, J=7.4 \mathrm{~Hz}, 2 \mathrm{H}), 4.42(\mathrm{~d}, J=7.6 \mathrm{~Hz}, 2 \mathrm{H}), 4.25(\mathrm{t}, J=7.6 \mathrm{~Hz}, 1 \mathrm{H}), 2.05(\mathrm{~s}, 3 \mathrm{H}) ;{ }^{13} \mathrm{C} \mathrm{NMR}(75$ $\left.\mathrm{MHz}, \mathrm{CDCl}_{3}\right) \delta 153.7,143.3,141.2,127.9,127.1,125.1,120.0,80.1,72.3,67.6,46.4,3.9$. Anal calcd for $\mathrm{C}_{18} \mathrm{H}_{14} \mathrm{O}_{2}$ : C, $82.42 \mathrm{H}$, 5.38. Found: C, 82.37, H, 5.47.

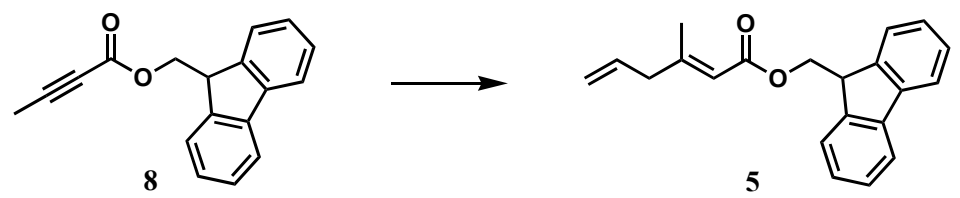

To a solution of allyltributyltin $(11.0 \mathrm{~mL}, 11.7 \mathrm{~g}, 35.5 \mathrm{mmol})$ in $\mathrm{THF}(100 \mathrm{~mL})$ at $-78^{\circ} \mathrm{C}$ was added $n$-BuLi (15.5 mL, 2.37 M in hexanes, $36.7 \mathrm{mmol})$. After $30 \mathrm{~min}$, the solution was added to a suspension of $\mathrm{CuI}(6.651 \mathrm{~g}, 34.9 \mathrm{mmol})$ in THF $(50 \mathrm{~mL})$ at $-78^{\circ} \mathrm{C}$. The solution was warmed to $-30^{\circ} \mathrm{C}$ over $45 \mathrm{~min}$, cooled to $-78^{\circ} \mathrm{C}$ and a solution of ester $8(6.008 \mathrm{~g}, 22.9 \mathrm{mmol})$ in $\mathrm{THF}(70 \mathrm{~mL})$ at $-78^{\circ} \mathrm{C}$ was added via cannula. After $15 \mathrm{~min}$, the reaction mixture was quenched with saturated $\mathrm{NH}_{4} \mathrm{Cl}$, warmed to room temperature, and diluted with ether and water. The aqueous phase was extracted with ether $(5 \mathrm{x})$ followed by EtOAc $(4 \mathrm{x})$ and the combined organic extracts were washed with saturated $\mathrm{NH}_{4} \mathrm{Cl}(1 \mathrm{x})$ and brine $(1 \mathrm{x})$, dried over $\mathrm{MgSO}_{4}$, and concentrated. Purification by flash column chromatography on silica gel (3\% to $6 \%$ EtOAc in 
petroleum ether) gave alkene $5(6.73 \mathrm{~g}, 97 \%)$ as a colorless oil: $R_{f}=0.41\left(10 \% \mathrm{Et}_{2} \mathrm{O} / 90 \%\right.$ petroleum ether); IR (film from $\mathrm{CH}_{2} \mathrm{Cl}_{2}$ ) 3067, 2940, 1954, 1908, $1714 \mathrm{~cm}^{-1} ;{ }^{1} \mathrm{H}$ NMR (300 $\left.\mathrm{MHz}, \mathrm{CDCl}_{3}\right) \delta 7.76(\mathrm{~d}, J=7.3 \mathrm{~Hz}, 2 \mathrm{H}), 7.61(\mathrm{~d}, J=7.6 \mathrm{~Hz}, 2 \mathrm{H}), 7.40(\mathrm{t}, J=6.8 \mathrm{~Hz}, 2 \mathrm{H}), 7.31$ (t, $J=7.3 \mathrm{~Hz}, 2 \mathrm{H}), 5.75-5.86(\mathrm{~m}, 2 \mathrm{H}), 5.17$ (s, $1 \mathrm{H}), 5.12$ (d, $J=7.1 \mathrm{~Hz}, 1 \mathrm{H}), 4.40(\mathrm{~d}, J=7.1 \mathrm{~Hz}$, $2 \mathrm{H}), 4.24(\mathrm{t}, J=7.1 \mathrm{~Hz}, 1 \mathrm{H}), 2.91(\mathrm{~d}, J=6.6 \mathrm{~Hz}, 2 \mathrm{H}), 2.14(\mathrm{~s}, 3 \mathrm{H}) ;{ }^{13} \mathrm{C} \mathrm{NMR}\left(75 \mathrm{MHz}, \mathrm{CDCl}_{3}\right)$ o 166.6, 158.8, 144.0, 141.3, 134.1, 127.7, 127.0, 125.0, 120.0, 117.9, 116.0, 65.7, 46.8, 45.0, 18.8. Anal calcd for $\mathrm{C}_{21} \mathrm{H}_{20} \mathrm{O}_{2}: \mathrm{C}, 82.86 \mathrm{H}, 6.62$. Found: $\mathrm{C}, 83.05, \mathrm{H}, 6.49$.

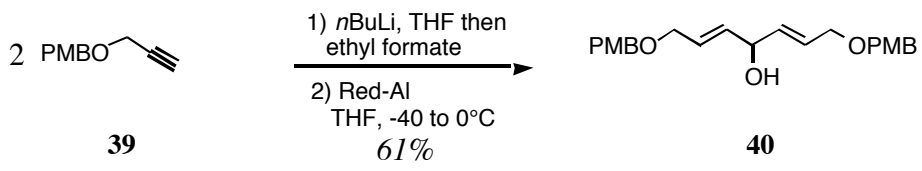

To a solution of $39(55.2 \mathrm{~g}, 313 \mathrm{mmol})$ in $350 \mathrm{~mL}$ of THF at $-78^{\circ} \mathrm{C}$ was added $115 \mathrm{~mL}$ (297 mmol) of a $2.58 \mathrm{M}$ solution of $n$-butyllithium in hexanes over 15 minutes. The resulting clear, pale yellow reaction mixture was allowed to stir at $-78{ }^{\circ} \mathrm{C}$ for $3.5 \mathrm{~h}$ whereupon $10.5 \mathrm{~g}$ (142 mmol) of ethyl formate was added dropwise via syringe over $5 \mathrm{~min}$ and the resulting mixture was stirred at $-78^{\circ} \mathrm{C}$ for $1 \mathrm{~h}$ then allowed to warm to rt over $1 \mathrm{~h}$. The reaction mixture was diluted with $300 \mathrm{~mL}$ of diethyl ether and $30 \mathrm{~mL}$ of saturated aqueous sodium bicarbonate was added dropwise followed by addition of $250 \mathrm{~mL}$ of water. The resulting layers were separated and the aqueous portion was extracted with additional diethyl ether $(3 \times 150 \mathrm{~mL})$ and the combined organic extracts were washed with brine $(3 \times 100 \mathrm{~mL})$, dried $\left(\mathrm{MgSO}_{4}\right)$, filtered, and concentrated in vacuo to afford $65 \mathrm{~g}$ of the crude bispropargylic alcohol intermediate (TLC $\mathrm{R}_{f}=0.58$ in $75 \%$ $\mathrm{Et}_{2} \mathrm{O}$ in petroleum ether) as an dark red/orange oil. This material was subjected to the next step without further purification due to its instability.

The crude propargyl alcohol was dissolved in $600 \mathrm{~mL}$ of THF and cooled to $-40{ }^{\circ} \mathrm{C}$ whereupon $149 \mathrm{~mL}$ ( $497 \mathrm{mmol}$ ) of $65 \% \mathrm{w} / \mathrm{w}$ solution of Red-Al in toluene was added dropwise via syringe over $30 \mathrm{~min}$ with concomitant hydrogen gas evolution. The resulting clear, reddishorange mixture was allowed to stir while warming from $-40{ }^{\circ} \mathrm{C}$ to $0{ }^{\circ} \mathrm{C}$ over $4.5 \mathrm{~h}$. The reaction was then carefully quenched at $0^{\circ} \mathrm{C}$ by dropwise addition of $30 \mathrm{~mL}$ of a $1 \mathrm{M}$ aqueous solution of Rochelle's salts causing vigorous gas evolution. The mixture was allowed to warm to $\mathrm{rt}$ whereupon and additional $150 \mathrm{~mL}$ of $1 \mathrm{M}$ aqueous Rochelle's salts, $100 \mathrm{~mL}$ of water, and 500 $\mathrm{mL}$ of diethyl ether were added followed by vigorous stirring for $2 \mathrm{~h}$. The resulting 
homogeneous layers were then separated and the aqueous phase was diluted with $200 \mathrm{~mL}$ of additional water before being extracted with diethyl ether $(3 \times 150 \mathrm{~mL})$. The combined organic extracts were washed with brine $(3 \times 100 \mathrm{~mL})$, dried $\left(\mathrm{MgSO}_{4}\right)$, filtered, and concentrated on a rotary evaporator to afford $69.5 \mathrm{~g}$ of the crude alcohol $\mathbf{4 0}$ containing residual solvents and 2methoxyethanol from quenching of the Red-Al reagent. The residual solvents and 2methoxyethanol were removed via Kugelrohr distillation at $70{ }^{\circ} \mathrm{C}$ at 1 Torr over 20-30 min to afford $59.4 \mathrm{~g}$ of a dark yellow/brown oil which was purified by flash chromatography on silica gel (elution with $75 \% \mathrm{Et}_{2} \mathrm{O}$ /petroleum ether) to deliver $33.2 \mathrm{~g}(61 \%)$ of pure $\mathbf{4 0}$ as a yellow oil. Due to the apparent instability of $\mathbf{4 0}$, this material was not stored for prolonged periods but was converted to its more stable silyl ether derivative 41. Physical data for 40: $\mathrm{TLC} \mathrm{R} f=0.35$ (75\% $\mathrm{Et}_{2} \mathrm{O}$ in petroleum ether). IR (film): 3414.6, 3001.4, 2838.7, 1612.3, 1585.9, 1246.6, 1033.3, 971.6, $818.5 \mathrm{~cm}^{-1} .1_{\mathrm{H}} \mathrm{NMR}\left(300 \mathrm{MHz}, \mathrm{CDCl}_{3}\right) \delta 7.24(\mathrm{~d}, J=8.8 \mathrm{~Hz}, 4 \mathrm{H}), 6.86(\mathrm{~d}, J=8.8 \mathrm{~Hz}$, 4 H), 5.85-5.71 (m, 4 H), 4.64 (br d, $J=3.9 \mathrm{~Hz}, 1 \mathrm{H}), 4.42$ (s, $4 \mathrm{H}), 3.98$ (d, $J=3.9 \mathrm{~Hz}, 4 \mathrm{H}$ ), 3.77 (s, $6 \mathrm{H}), 2.24$ (d, $J=3.9 \mathrm{~Hz}, 1 \mathrm{H}) .{ }^{13} \mathrm{C} \mathrm{NMR}\left(75 \mathrm{MHz}, \mathrm{CDCl}_{3}\right)$ 8159.04, 133.77, 130.08, $129.28,127.62,113.65,72.11,71.82,69.59,55.13$.

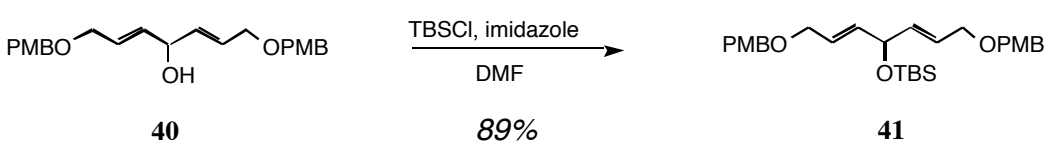

To a solution of alcohol $40(29.3 \mathrm{~g}, 0.076 \mathrm{mmol})$ in $100 \mathrm{~mL}$ of DMF at $0^{\circ} \mathrm{C}$ were successively added $15.5 \mathrm{~g}(0.228 \mathrm{mmol})$ of imidazole and $14.9 \mathrm{~g}(0.099 \mathrm{mmol})$ of $t$ butyldimethylsilyl chloride. The resulting mixture was allowed to warm to rt and stir for $48 \mathrm{~h}$ then poured into $300 \mathrm{~mL}$ of saturated aqueous ammonium chloride and $300 \mathrm{~mL}$ of diethyl ether. The mixture was stirred until two homogeneous layers resulted ( $2 \mathrm{~min})$ and the layers were separated. The aqueous phase was extracted with diethyl ether $(3 \times 150 \mathrm{~mL})$ and the combined organic extracts were washed with water $(3 \times 80 \mathrm{~mL})$, brine $(3 \times 50 \mathrm{~mL})$, then dried $\left(\mathrm{MgSO}_{4}\right)$, filtered, and concentrated in vacuo to give $39.4 \mathrm{~g}$ of crude $\mathbf{4 1}$ as a golden yellow oil. Flash chromatography on silica gel (elution with $20 \% \mathrm{Et}_{2} \mathrm{O}$ in petroleum ether) afforded $33.7 \mathrm{~g} \mathrm{(89 \% )}$ of pure 41 as pale yellow oil. $T L C \mathrm{R}_{\mathrm{f}}=0.40$ ( $20 \% \mathrm{Et}_{2} \mathrm{O}$ in petroleum ether). IR (film): 2930.6, $2855.1,1613.0,1585.9,1513.7,1249.0,1102.6,835.9,776.8 \mathrm{~cm}^{-1} .{ }^{1} \mathrm{H} \mathrm{NMR}\left(300 \mathrm{MHz}, \mathrm{CDCl}_{3}\right)$

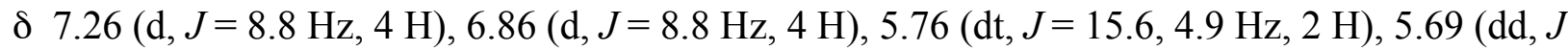


= 15.6, 4.4 Hz, $2 \mathrm{H}), 4.68(\operatorname{app~t}, J=4.4 \mathrm{~Hz}, 1 \mathrm{H}), 4.43(\mathrm{~s}, 4 \mathrm{H}), 3.99$ (d, $J=4.9 \mathrm{~Hz}, 4 \mathrm{H}), 3.79$ (s, $6 \mathrm{H}), 0,91$ (s, $9 \mathrm{H}), 0.07$ (s, $6 \mathrm{H}) .{ }^{13} \mathrm{C} \mathrm{NMR}\left(75 \mathrm{MHz}, \mathrm{CDCl}_{3}\right)$ 8159.08, 134.94, 130.29, 129.31, 126.15, 113.68, 72.83, 71.56, 69.77, 55.19, 25.84, 18.30, -4.66. Anal. Calcd for $\mathrm{C}_{29} \mathrm{H}_{42} \mathrm{SiO}_{5}:$ C, 69.84; H, 8.49. Found: C, 69.70; H, 8.34.

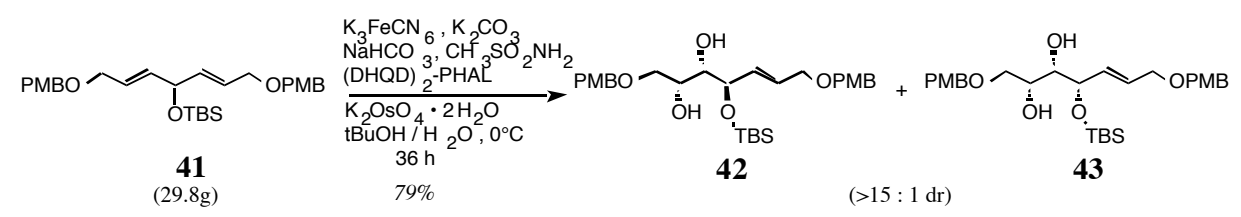

To a mixture of potassium hexaferricyanide $(59.1 \mathrm{~g}, 179 \mathrm{mmol})$, potassium carbonate (24.8 g, $179 \mathrm{mmol})$, sodium bicarbonate (15.1 g, $179 \mathrm{mmol})$, methanesulfonamide (5.69 g, 59.8 mmol), (DHQD) 2 -PHAL (0.935 g, $1.20 \mathrm{mmol})$, potassium osmate(VI) dihydrate $(0.220 \mathrm{~g}, 0.598$ mmol) was added $300 \mathrm{~mL}$ of water and $250 \mathrm{~mL}$ of tert-butanol and the resulting mixture was stirred at $\mathrm{rt}$ for $15 \mathrm{~min}$ to afford a homogeneous solution. The mixture was then cooled to $0^{\circ} \mathrm{C}$ at which time a suspension of $29.8 \mathrm{~g}(59.8 \mathrm{mmol})$ of $\mathbf{4 1}$ in $50 \mathrm{~mL}$ of tert-butanol was added via pipette. The reaction mixture was vigorously stirred at $0^{\circ} \mathrm{C}$ for $38 \mathrm{~h}$ then quenched at $0^{\circ} \mathrm{C}$ by the addition of $82 \mathrm{~g}$ of sodium sulfite. The resulting mixture was allowed to warm to $\mathrm{rt}$ with stirring over $1 \mathrm{~h}$ then $250 \mathrm{~mL}$ of water and $500 \mathrm{~mL}$ of ethyl acetate were added. The resulting layers were separated and the aqueous portion was extracted with additional ethyl acetate $(3 \times 200 \mathrm{~mL})$. The combined organic layers were then washed with $2 \mathrm{~N}$ aqueous sodium hydroxide solution (2 x $200 \mathrm{~mL})$, water $(2 \times 150 \mathrm{~mL})$, and brine $(2 \times 200 \mathrm{~mL})$, then dried over $\mathrm{MgSO}_{4}$, filtered, and concentrated in vacuo to afford $31.5 \mathrm{~g}$ of the crude diol as a dark yellow/green oil. Purification of the product by flash chromatography on silica gel (elution with $70 \% \mathrm{Et}_{2} \mathrm{O}$ in petroleum ether) yielded $25.02 \mathrm{~g} \mathrm{(79 \% )} \mathrm{of} \mathrm{a} \mathrm{pale} \mathrm{yellow} \mathrm{oil} \mathrm{as} \mathrm{the} \mathrm{inseparable} \mathrm{diols} \mathbf{4 2}$ and $\mathbf{4 3}$ in a >15:1 diastereoselectivity. Physical data for $\mathbf{4 2}$ (major diastereomer): $\mathrm{TLC} \mathrm{R}_{\mathrm{f}}=0.21\left(50 \% \mathrm{Et}_{2} \mathrm{O}\right.$ in petroleum ether). IR (film): 3474.6, 2953.9, 2856.6, 1613.2, 1586.3, 1248.8, 1099.8, 837.2, $778.9 \mathrm{~cm}^{-1}$. ${ }^{1} \mathrm{H}$ NMR $\left(300 \mathrm{MHz}, \mathrm{CDCl}_{3}\right) \delta 7.24(\mathrm{~d}, J=8.8 \mathrm{~Hz}, 2 \mathrm{H}), 7.22$ (overlapping d, $J=8.8$ $\mathrm{Hz}, 2 \mathrm{H}), 6.86$ (d, $J=8.8 \mathrm{~Hz}, 2 \mathrm{H}), 6.84$ (overlapping d, $J=8.8 \mathrm{~Hz}, 2 \mathrm{H}$ ), 5.82 (dt, $J=15.6,4.9$ $\mathrm{Hz}, 1 \mathrm{H}), 5.72$ (dd, $J=15.6,5.9 \mathrm{~Hz}, 1 \mathrm{H}), 4.46$ (m, 2 H), 4.42 (s, $2 \mathrm{H}), 4.36$ (app t, $J=4.9 \mathrm{~Hz}, 1$ H), 4.28 (br m, 1 H), 3.99 (d, $J=4.9 \mathrm{~Hz}, 2 \mathrm{H}$ ), 3.78 (s, $3 \mathrm{H}$ ), 3.77 (s, $3 \mathrm{H}$ ), 3.54 (dd, $J=5.9,1.5$ $\mathrm{Hz}, 2 \mathrm{H}), 3.48$ (app t, $J=5.9 \mathrm{~Hz}, 1 \mathrm{H}), 3.17$ (d, $J=3.4 \mathrm{~Hz}, 1 \mathrm{H}), 2.88(\mathrm{~d}, J=6.8 \mathrm{~Hz}, 1 \mathrm{H}), 0.90$ 
(s, $9 \mathrm{H}), 0.11(\mathrm{~s}, 3 \mathrm{H}), 0.06(\mathrm{~s}, 3 \mathrm{H}) .{ }^{13} \mathrm{C} \mathrm{NMR}\left(75 \mathrm{MHz}, \mathrm{CDCl}_{3}\right) \delta$ 159.17, 159.08, 131.99, $130.13,129.79,129.36,129.23,129.03,113.71,113.68,93.94,75.75,73.52,73.13,71.98,71.56$, 69.46, 68.62, 55.14, 22.74, 18.00, -4.46, -5.08. Anal. Calcd for $\mathrm{C}_{29} \mathrm{H}_{44} \mathrm{SiO}_{7}$ : C, 65.38; H, 8.32. Found: C, 65.16; H, 8.18.

Physical data for 43 (minor diastereomer): $\mathrm{TLC} \mathrm{Rf}=0.21\left(50 \% \mathrm{Et} 2 \mathrm{O}\right.$ in petroleum ether). ${ }^{1} \mathrm{H}$ NMR $\left(300 \mathrm{MHz}, \mathrm{CDCl}_{3}\right) \delta 7.24(\mathrm{~d}, J=8.8 \mathrm{~Hz}, 4 \mathrm{H}), 6.86(\mathrm{~d}, J=8.8 \mathrm{~Hz}, 2 \mathrm{H}), 6.84$ (overlapping $\mathrm{d}, J=8.8 \mathrm{~Hz}, 2 \mathrm{H}), 5.82(\mathrm{dt}, J=15.6,4.9 \mathrm{~Hz}, 1 \mathrm{H}), 5.72(\mathrm{dd}, J=15.6,5.9 \mathrm{~Hz}, 1 \mathrm{H}), 4.46(\mathrm{~m}, 2$ H), $4.42(\mathrm{~m}, 2 \mathrm{H}), 4.27$ (app t, $J=5.9 \mathrm{~Hz}, 1 \mathrm{H}), 3.98(\mathrm{~d}, J=4.4 \mathrm{~Hz}, 2 \mathrm{H}), 3.82(\mathrm{~m}, 1 \mathrm{H}), 3.78$ (s, $3 \mathrm{H}), 3.77$ (s, $3 \mathrm{H}), 3.53$ (m, 2 H), 3.48-3.44 (m, 1 H), 3.17 (br s, $1 \mathrm{H}), 2.80$ (br s, $1 \mathrm{H}), 0.88$ (s, 9H), 0.06 (s, $3 \mathrm{H}), 0.04$ (s, $3 \mathrm{H})$.

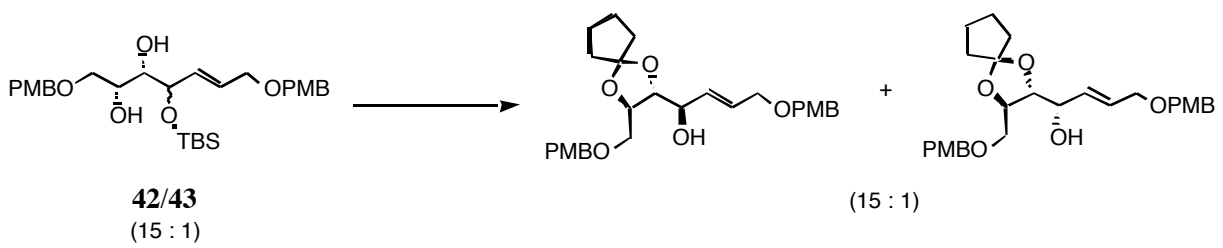

A solution of the inseparable diastereomeric diols 42/43 (25.2 g, $47.5 \mathrm{mmol})$ in $150 \mathrm{~mL}$ of $\mathrm{CH}_{2} \mathrm{Cl}_{2}$ and $61.8 \mathrm{~g}(475 \mathrm{mmol})$ of 1,1-dimethoxycyclopentane at $0^{\circ} \mathrm{C}$ was treated with $p$ toluenesulfonic acid $(0.270 \mathrm{~g}, 1.42 \mathrm{mmol})$. After stirring at $0^{\circ} \mathrm{C}$ for $1.75 \mathrm{~h}$, the reaction mixture was neutralized by the addition of solid $\mathrm{NaHCO}_{3}(\mathrm{ca} .2 \mathrm{~g})$ and allowed to warm to rt and stir overnight. Filtration of the mixture through a short pad of silica gel $(3 \times 7 \mathrm{~cm})$ washing with 200 $\mathrm{mL}$ of additional diethyl ether then provided a clear filtrate which was concentrated in vacuo on a rotary evaporator to provide approximately $75 \mathrm{~mL}$ of the crude acetal intermediate $(\mathrm{TLC} \mathrm{Rf}=$ $0.90,70 \% \mathrm{Et}_{2} \mathrm{O}$ in petroleum ether) as a pale yellow liquid which contained some residual 1,1dimethoxycyclopentane.

The crude material was dissolved in $100 \mathrm{~mL}$ of anhydrous THF and the solution was cooled to $0^{\circ} \mathrm{C}$ whereupon $57 \mathrm{~mL}(57.0 \mathrm{mmol})$ of a $1.0 \mathrm{M}$ solution of TBAF in THF was added dropwise. The resulting mixture was stirred at $0^{\circ} \mathrm{C}$ for $2 \mathrm{~h}$ and at $\mathrm{rt}$ for $14 \mathrm{~h}$ then the mixture was partitioned between $50 \mathrm{~mL}$ of saturated aqueous ammonium chloride solution and $50 \mathrm{~mL}$ of diethyl ether and the layers were separated. The aqueous phase was extracted with additional diethyl ether $(3 \times 50 \mathrm{~mL})$ and the combined organic extracts were washed with brine $(3 \times 30$ 
$\mathrm{mL}$ ), dried over $\mathrm{MgSO}_{4}$, filtered, and concentrated in vacuo on a rotary evaporator to afford the crude product as an orange liquid which contained residual 1,1-dimethoxycyclopentane.

Purification by flash chromatography on silica gel initially eluting with $70 \% \mathrm{Et}_{2} \mathrm{O}$ in petroleum ether then increasing to $80 \% \mathrm{Et}_{2} \mathrm{O}$ in petroleum ether provided $21.5 \mathrm{~g}(94 \%)$ of an inseparable 13 : 1 diastereomeric mixture of as a pale yellow oil.

Physical data for the major diastereomer: $\mathrm{TLC} \mathrm{Rf}_{\mathrm{f}}=0.31\left(70 \% \mathrm{Et}_{2} \mathrm{O}\right.$ in petroleum ether). IR (film): 3442.1, 2954.8, 2869.3, 1612.7, 1586.0, 1513.8, 1248.4, 1107.7, 1035.0, 975.3, 820.0 $\mathrm{cm}^{-1} .{ }^{1} \mathrm{H}$ NMR $\left(300 \mathrm{MHz}, \mathrm{CDCl}_{3}\right) \delta 7.24(\mathrm{~d}, J=8.3 \mathrm{~Hz}, 2 \mathrm{H}), 7.22$ (overlapping d, $J=8.3 \mathrm{~Hz}, 2$ H), $6.84(\mathrm{~d}, J=8.3 \mathrm{~Hz}, 4 \mathrm{H}), 5.90(\mathrm{dt}, J=15.6,5.9 \mathrm{~Hz}, 1 \mathrm{H}), 5.74(\mathrm{dd}, J=15.6,5.4 \mathrm{~Hz}, 1 \mathrm{H})$, 4.48 (s, 2H), 4.40 (s, 2 H), 4.21 (br m, 1 H), 4.06 (dd, J=12.2, 5.4 Hz, 1 H), 3.96 (d, $J=5.4$ Hz, $2 \mathrm{H}), 3.76(\mathrm{~s}, 6 \mathrm{H}), 3.69$ (dd, $J=7.3,5.9 \mathrm{~Hz}, 1 \mathrm{H}), 3.57(\mathrm{dd}, J=10.3,5.4 \mathrm{~Hz}, 1 \mathrm{H}), 3.50(\mathrm{dd}, J=$ 10.3, 5.4 Hz, 1 H), 2.91 (br s, $1 \mathrm{H}), 1.89-1.71$ (m, $4 \mathrm{H}), 1.71-1.64$ (m, $4 \mathrm{H}) .{ }^{13} \mathrm{C} \mathrm{NMR}(75 \mathrm{MHz}$, $\left.\mathrm{CDCl}_{3}\right) \delta 159.12,159.00,130.99,130.15,129.48,129.29,129.21,128.71,119.20,113.65$, $113.58,80.96,76.81,73.02,71.56,71.52,70.30,69.56,55.06,37.22,37.07,36.97,23.42,23.24$. Anal. Calcd for $\mathrm{C}_{28} \mathrm{H}_{36} \mathrm{O}_{7}$ : C, 69.40; H, 7.49. Found: C, 69.19; H, 7.30.

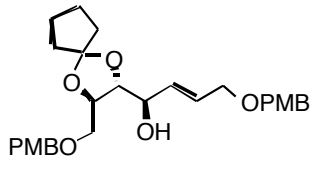

(15:1 dr)

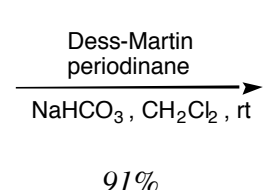

$91 \%$

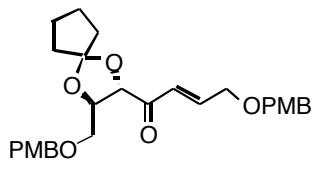

44
$(90 \%$ ee $)$

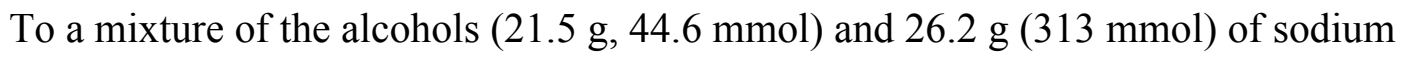
bicarbonate in $250 \mathrm{~mL}$ of methylene chloride at $0^{\circ} \mathrm{C}$ was added $24.6 \mathrm{~g}(57.9 \mathrm{mmol})$ of DessMartin periodinane as a solid over 1 minute. The resulting heterogeneous mixture was allowed to warm to rt and stir for $30 \mathrm{~min}$, then the mixture was cooled to $0^{\circ} \mathrm{C}$ whereupon three $50 \mathrm{~mL}$ portions of $1 \mathrm{~N}$ aqueous sodium sulfite solution was slowly added over 15 minutes. After warming to rt and stirring vigorously for an additional $2 \mathrm{~h}, 50 \mathrm{~mL}$ of water was added and the resulting layers were separated. The aqueous portion was extracted with diethyl ether $(3 \times 75$ $\mathrm{mL})$. The combined extracts were washed with brine $(2 \times 75 \mathrm{~mL})$, dried over $\mathrm{MgSO}_{4}$, filtered, and concentrated in vacuo to afford $22.8 \mathrm{~g}$ of the crude enone as a yellow oil. Purification by flash chromatography (elution with $40 \% \mathrm{Et}_{2} \mathrm{O}$ in petroleum ether) provided $19.5 \mathrm{~g}(91 \%)$ of pure 
44 as a pale yellow oil. Enantiomeric purity of $\mathbf{4 4}$ was determined to be $90 \%$ ee by chiral HPLC analysis : Chiralpak $\mathrm{AD}$ at $23^{\circ} \mathrm{C}, 1.0 \mathrm{~mL} / \mathrm{min}$ flow rate, $20 \%$ isopropanol-heptane, $254 \mathrm{~nm}$, retention times for enantiomers of $44: 12.03 \mathrm{~min}$ (minor), $13.20 \mathrm{~min}$ (major) as compared to a racemic standard of 44. TLC $\mathrm{Rf}_{\mathrm{f}}=0.65$ (60\% $\mathrm{Et}_{2} \mathrm{O}$ in petroleum ether). IR (film): 2955.9, 2869.4, 1691.8, 1629.7, 1612.7, 1513.9, 1248.4, 1110.8, 1034.7, 819.4 $\mathrm{cm}^{-1}$. ${ }^{1} \mathrm{H}$ NMR (300 $\left.\mathrm{MHz}, \mathrm{CDCl}_{3}\right) \delta 7.24(\mathrm{~d}, J=8.3 \mathrm{~Hz}, 4 \mathrm{H}), 7.04(\mathrm{dt}, J=15.6,3.9 \mathrm{~Hz}, 1 \mathrm{H}), 6.88-6.78(\mathrm{~m}, 5 \mathrm{H})$, 4.52 (s, 2 H), 4.47 (s, 2 H), 4.32 (d, J=7.3 Hz, 1 H), 4.25-4.20 (m, 1 H), 4.16-4.14 (m, 2 H), $3.78(\mathrm{~s}, 3 \mathrm{H}), 3.77$ (s, $3 \mathrm{H}), 3.68(\mathrm{dd}, J=10.7,3.9 \mathrm{~Hz}, 1 \mathrm{H}), 3.59(\mathrm{dd}, J=10.7,5.4 \mathrm{~Hz}, 1 \mathrm{H})$, 1.91-1.86 (m, $2 \mathrm{H}), 1.83-1.76(\mathrm{~m}, 2 \mathrm{H}), 1.73-1.68$ (m, $4 \mathrm{H}) .{ }^{13} \mathrm{C} \mathrm{NMR}\left(75 \mathrm{MHz}, \mathrm{CDCl}_{3}\right)$ ठ $197.58,159.22,159.11,145.15,129.81,129.57,129.28,129.19,123.98,120.86,113.73$, 113.65, 80.90, 77.31, 73.05, 72.37, 69.77, 68.51, 55.14 (two carbons), 36.73, 36.57, 23.56, 23.16. Anal. Calcd for $\mathrm{C}_{28} \mathrm{H}_{34} \mathrm{O}_{7}$ : C, 69.69; H, 7.10. Found: C, 69.72; H, 6.88. $[\alpha]_{\mathrm{D}}{ }^{26}=+$ $8.43\left(\right.$ c $1.79, \mathrm{CH}_{2} \mathrm{Cl}_{2}$ ).

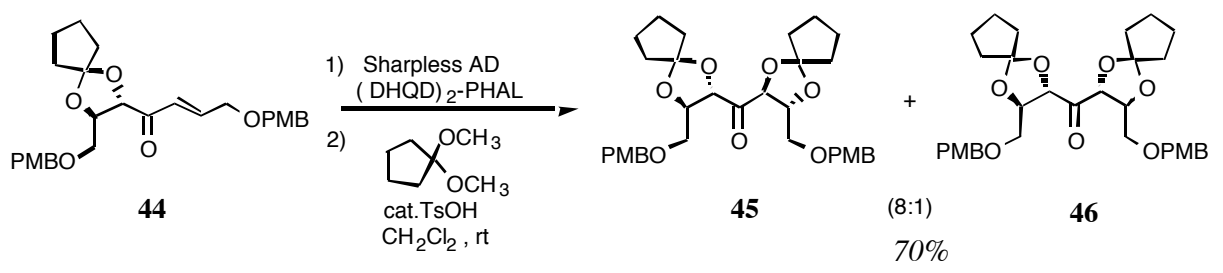

A 1-L round-bottomed flask was charged with potassium hexaferricyanide $(40.2 \mathrm{~g}, 122$ $\mathrm{mmol})$, potassium carbonate $(16.9 \mathrm{~g}, 122 \mathrm{mmol})$, sodium bicarbonate $(10.2 \mathrm{~g}, 122 \mathrm{mmol})$, methanesulfonamide (3.86 g, $40.6 \mathrm{mmol})$, (DHQD) 2 -PHAL (0.950 g, $1.22 \mathrm{mmol}$ ), and potassium osmate(VI) dihydrate $(0.450 \mathrm{~g}, 1.22 \mathrm{mmol})$ and $175 \mathrm{~mL}$ of water and $100 \mathrm{~mL}$ of tert-butanol was added. The mixture was stirred vigorously at $\mathrm{rt}$ for $10 \mathrm{~min}$ then cooled to $0^{\circ} \mathrm{C}$ and stirred for an additional 15 minutes. At this time, a suspension of $19.5 \mathrm{~g}(40.6 \mathrm{mmol})$ of 44 in $50 \mathrm{~mL}$ of tertbutanol was added via pipette. The flask was rinsed with $25 \mathrm{~mL}$ of additional tert-butanol and the rinse was added. The resulting orange, heterogeneous reaction mixture was vigorously stirred at $0-3^{\circ} \mathrm{C}$ for $24 \mathrm{~h}$ then quenched by the addition of $70 \mathrm{~g}$ of sodium sulfite along with 300 $\mathrm{mL}$ of water followed by warming to $\mathrm{rt}$ over $1 \mathrm{~h}$ with vigorous stirring. After adding $400 \mathrm{~mL}$ of ethyl acetate, the layers were separated and the aqueous portion was extracted with additional ethyl acetate $(3 \times 350 \mathrm{~mL})$. The combined organic extracts were washed with $1 \mathrm{~N}$ aqueous 
sodium hydroxide $(2 \times 300 \mathrm{~mL})$, water $(4 \times 300 \mathrm{~mL})$, and brine $(3 \times 200 \mathrm{~mL})$, then dried over anhydrous magnesium sulfate, filtered and concentrated in vacuo to afford a yellow-green oil as the crude diol. This material was dissolved in diethyl ether $(\sim 300 \mathrm{~mL})$ and the solution was filtered through a short pad of silica gel $(3 \times 8 \mathrm{~cm})$ eluting with an additional liter of diethyl ether. The resulting clear filtrate was concentrated in vacuo to afford $18.03 \mathrm{~g}$ of a white solid as the partially purified diol intermediate ( $\mathrm{TLC} \mathrm{R}_{\mathrm{f}}=0.25,50 \% \mathrm{Et}_{2} \mathrm{O}$ in petroleum ether).

The diol mixture was dissolved in $400 \mathrm{~mL}$ of anhydrous methylene chloride and $52.8 \mathrm{~g}$ (406 mmol) of 1,1-dimethoxycyclopentane was added. After cooling the mixture to $0^{\circ} \mathrm{C}, 0.463 \mathrm{~g}$ ( $2.44 \mathrm{mmol})$ of $p$-toluenesulfonic acid hydrate was added and the resulting mixture was stirred at $0^{\circ} \mathrm{C}$ for $4 \mathrm{~h}$ then ca. $3 \mathrm{~g}$ of solid sodium bicarbonate was added and the mixture was warmed to $\mathrm{rt}$ and stirred overnight $(14 \mathrm{~h})$. The contents were filtered and concentrated on a rotary evaporator to remove the solvents to give the desired product which contained the excess 1,1dimethoxycyclopentane. Since the desired product appeared to be unstable to silica gel chromatography due to significant "streaking" of the product when analyzed by TLC $\left(50 \% \mathrm{Et}_{2} \mathrm{O}\right.$ in petroleum ether, $\mathrm{R}_{\mathrm{f}}=0.63$ ), the 1,1-dimethoxypentane was removed by Kugelrohr distillation by heating the crude mixture to $60^{\circ} \mathrm{C}$ at 0.2 Torr for 30 minutes. The purified product $(20.6 \mathrm{~g}$, $88 \%$ ) was then recovered from the distillation pot as an $8: 1$ diasteromeric mixture of $\mathbf{4 5}$ and $\mathbf{4 6}$ respectively, as a yellow oil. The diastereomeric ratio of $8: 1$ was determined by the relative integration areas of the major diastereomer resonance at $4.29 \mathrm{ppm}(\mathrm{m}, 2 \mathrm{H})$ compared to the minor diastereomer resonance at $4.21 \mathrm{ppm}(\mathrm{m}, 2 \mathrm{H})$. Due to the apparent instability of the product, a satisfactory elemental analysis was not obtained. Physical data for $\mathbf{4 5}$ (major diastereomer) : $\mathrm{TLC} \mathrm{R}_{\mathrm{f}}=0.63$ (50\% $\mathrm{Et}_{2} \mathrm{O}$ in petroleum ether). IR (film): 2956.6, 2872.0, $1730.3,1612.7,1586.1,1513.9,1248.5,1106.0,973.8,820.3 \mathrm{~cm}^{-1} .{ }^{1} \mathrm{H}$ NMR $\left(300 \mathrm{MHz}, \mathrm{CDCl}_{3}\right)$ $\delta 7.22(\mathrm{~d}, J=8.8 \mathrm{~Hz}, 4 \mathrm{H}), 6.84$ (d, $J=8.8 \mathrm{~Hz}, 4 \mathrm{H}), 4.56$ (d, $J=6.8 \mathrm{~Hz}, 2 \mathrm{H}), 4.48$ (s, $4 \mathrm{H})$, 4.29 (m, 2 H), 3.77 (s, 6 H), 3.63 (dd, $J=10.2,4.4$. Hz, 2 H), 3.57 (dd, $J=10.2,5.4$ Hz, 2 H),

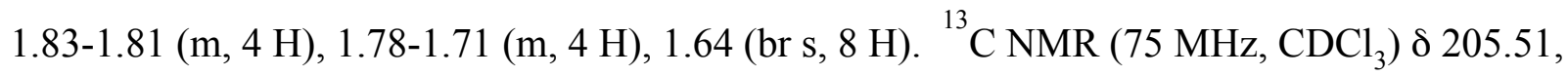
$159.19,129.78,129.34,121.18,113.69,79.62,76.68,73.10,69.75,55.19,36.86,36.65,23.56$, 23.24 . 

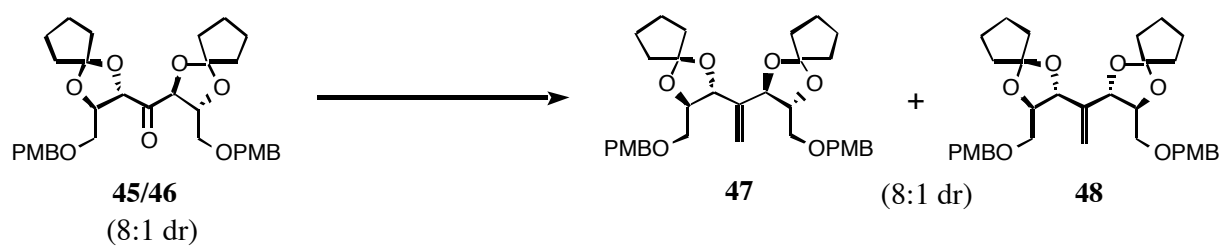

To a solution of $20.6 \mathrm{~g}(35.4 \mathrm{mmol})$ of $\mathbf{4 5} / \mathbf{4 6}$ in $100 \mathrm{~mL}$ of $\mathrm{THF}$ at $0^{\circ} \mathrm{C}$ was added 106 $\mathrm{mL}$ (106 mmol) of a 1.0 M solution of trimethylsilylmethylmagnesium chloride in diethyl ether over 15 minutes. The resulting clear yellow solution was allowed to warm to rt and stir for $4 \mathrm{~h}$ then carefully quenched by a slow, dropwise addition of $50 \mathrm{~mL}$ of water causing vigorous bubbling of the reaction mixture. After $30 \mathrm{~min}, 200 \mathrm{~mL}$ of saturated aqueous ammonium chloride and $200 \mathrm{~mL}$ of diethyl ether were then added and the mixture was stirred vigorously for $1 \mathrm{~h}$. The resulting layers were separated and the aqueous portion was extracted with additional diethyl ether $(3 \times 200 \mathrm{~mL})$. The combined organic extracts were washed with brine $(3 \times 50 \mathrm{~mL})$, dried over magnesium sulfate, filtered, and concentrated in vacuo to afford $23.6 \mathrm{~g}$ of the crude hydroxysilane intermediate as a yellow oil.

The crude hydroxysilane was dissolved in $200 \mathrm{~mL}$ of anhydrous THF and $141.4 \mathrm{~mL}$ (70.7 mmol) of a $0.5 \mathrm{M}$ solution of potassium hexamethyldisilazide (KHMDS) in toluene was added. The resulting mixture was stirred at $\mathrm{rt}$ for $18 \mathrm{~h}$ then partitioned between $300 \mathrm{~mL}$ of water and $200 \mathrm{~mL}$ of diethyl ether. The aqueous portion was extracted with diethyl ether (3 x $150 \mathrm{~mL})$ and the combined organic extracts were washed with brine $(3 \times 100 \mathrm{~mL})$, dried over magnesium sulfate, filtered, and concentrated in vacuo to give $20.3 \mathrm{~g}$ of a yellow oil as the crude product. Purification by flash chromatography on silica gel eluting with 35\% diethyl ether in petroleum ether afforded $14.8 \mathrm{~g} \mathrm{(72 \% )} \mathrm{of} \mathrm{pure} \mathrm{47/48} \mathrm{in} \mathrm{an} \mathrm{8:1} \mathrm{diastereomeric} \mathrm{mixture} \mathrm{as} \mathrm{a} \mathrm{pale} \mathrm{yellow} \mathrm{oil.}$ The diastereomeric ratio was determined by the relative integration areas of the major diastereomer resonance at $5.36 \mathrm{ppm}(\mathrm{s}, 2 \mathrm{H})$ compared to the minor diastereomer resonance at $5.31 \mathrm{ppm}(\mathrm{s}, 2 \mathrm{H})$. Physical data for 47 (major diastereomer) : TLC $\mathrm{Rf}_{\mathrm{f}}=0.70\left(60 \% \mathrm{Et}_{2} \mathrm{O}\right.$ in petroleum ether). IR (film): 2956.1, 2871.4, 1650.6, 1612.8, 1586.1, 1513.9, 1248.1, 1101.8, 1035.4, 820.2 $\mathrm{cm}^{-1}$. ${ }^{1} \mathrm{H}$ NMR $\left(300 \mathrm{MHz}, \mathrm{CDCl}_{3}\right) \delta 7.22(\mathrm{~d}, J=8.8 \mathrm{~Hz}, 4 \mathrm{H}), 6.84(\mathrm{~d}, J=8.8$ Hz, 4 H), 5.36 (s, 2 H), 4.46 (s, 4 H), 4.22 (d, J= 7.8 Hz, 2 H), 4.07-4.02 (m, 2 H), 3.76 (s, 6 H), $3.56(\mathrm{dd}, J=10.3,3.4 \mathrm{~Hz}, 2 \mathrm{H}), 3.48$ (dd, $J=10.7,5.4 \mathrm{~Hz}, 2 \mathrm{H}), 1.86-1.82$ (m, $4 \mathrm{H}), 1.80-1.72$ (m, $4 \mathrm{H}), 1.66-1.58(\mathrm{~m}, 8 \mathrm{H}) .{ }^{13} \mathrm{C} \mathrm{NMR}\left(75 \mathrm{MHz} \mathrm{CDCl}_{3}\right) \delta$ 159.09, 143.14, 129.94, 129.26, 
119.07, 115.76, 113.61, 79.91, 78.00, 72.99, 69.36, 55.13, 37.34, 37.04, 23.53, 23.32. Anal.

Calcd for $\mathrm{C}_{34} \mathrm{H}_{44} \mathrm{O}_{8}$ : C, 70.32; H, 7.64. Found: C, 70.34; H, 7.80.

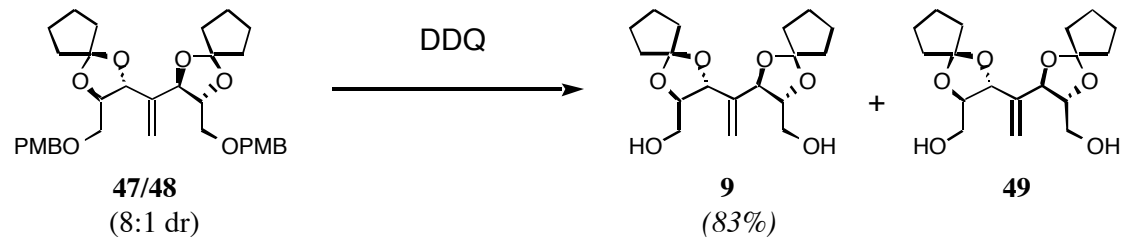

To a $0^{\circ} \mathrm{C}$ solution of $11.5 \mathrm{~g}(19.8 \mathrm{mmol})$ of $47 / 48$ in $250 \mathrm{~mL}$ of methylene chloride at $\mathrm{rt}$ were successively added $7.6 \mathrm{~mL}$ of water and $13.5 \mathrm{~g}(59.4 \mathrm{mmol})$ of DDQ. The resulting dark green mixture was allowed to warm to rt and stir for $1.25 \mathrm{~h}$ and the resulting tan, heterogeneous mixture was filtered through a pad of celite to remove the solids and the pad was washed with $200 \mathrm{~mL}$ of additional methylene chloride. The resulting filtrate was washed with saturated aqueous sodium sulfite $(3 \times 80 \mathrm{~mL})$, saturated aqueous sodium bicarbonate $(80 \mathrm{~mL})$, and brine $(100 \mathrm{~mL})$. The solution was dried over anhydrous magnesium sulfate, filtered, and concentrated in vacuo to provide approximately $13 \mathrm{~g}$ of the crude diol mixture as a yellow liquid. Purification by flash chromatography (gradient elution from $80 \% \mathrm{Et}_{2} \mathrm{O}$ in petroleum ether to $100 \% \mathrm{Et}_{2} \mathrm{O}$ ) initially afforded fractions containing the less polar minor diastereomer $\mathbf{7 0}\left(\mathrm{TLC} \mathrm{R}_{\mathrm{f}}=0.48,100\right.$ $\left.\% \mathrm{Et}_{2} \mathrm{O}\right)$ with later fractions providing $5.6 \mathrm{~g}(83 \%)$ of the pure major diastereomer 57 as a pale yellow oil. Physical data for 57 (major diastereomer) : TLC $\mathrm{R}_{\mathrm{f}}=0.36\left(100 \% \mathrm{Et}_{2} \mathrm{O}\right)$. IR (film): 3431.3, 2958.6, 2874.4, 1649.8, 1334.5, 1112.0, 1039.7, $985.6 \mathrm{~cm}^{-1}$. ' H NMR (300 MHz, $\left.\mathrm{CDCl}_{3}\right) \delta 5.42$ (s, $\left.2 \mathrm{H}\right), 4.32$ (d, $\left.J=8.3 \mathrm{~Hz}, 2 \mathrm{H}\right), 3.98$ (app dt, $\left.J=7.8,3.9 \mathrm{~Hz}, 2 \mathrm{H}\right), 3.82$ (dd, $J=$ 12.2, $3.4 \mathrm{~Hz}, 2 \mathrm{H}), 3.64$ (dd, $J=12.2,3.9 \mathrm{~Hz}, 2 \mathrm{H}), 2.46$ (br s, $2 \mathrm{H}), 1.86-1.76$ (m, 8 H), 1.711.57 (m, $8 \mathrm{H}) .{ }^{13} \mathrm{C} \mathrm{NMR}\left(75 \mathrm{MHz}, \mathrm{CDCl}_{3}\right) \delta$ 142.61, 118.98, 115.66, 80.98, 77.26, 61.43, 37.23, 37.02, 23.23, 23.20. Anal. Calcd for $\mathrm{C}_{18} \mathrm{H}_{28} \mathrm{O}_{6}$ : C, 63.51: H, 8.29. Found: $\mathrm{C}, 63.67, \mathrm{H}$, 8.14. $[\alpha]_{\mathrm{D}}{ }^{24}=+6.44\left(\mathrm{c} 1.79, \mathrm{CH}_{2} \mathrm{Cl}_{2}\right)$.

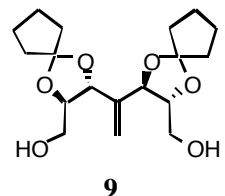

9 a) 1.0 eq. $\mathrm{NaH}, \mathrm{THF}$

b) 1.0 eq TBSCl

$80 \%$

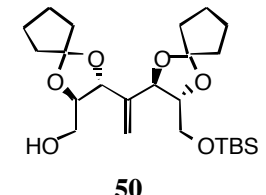

50 
To a suspension of $0.73 \mathrm{~g}(18.2 \mathrm{mmol})$ of $60 \%$ sodium hydride dispersion in mineral oil in $80 \mathrm{~mL}$ of THF at rt was added a solution of $5.9 \mathrm{~g}(17.3 \mathrm{mmol})$ of diol 9 in $30 \mathrm{~mL}$ of THF via cannula. The resulting mixture was allowed to stir at $\mathrm{rt}$ for $5 \mathrm{~h}$ affording a thick, heterogeneous mixture which became difficult to stir. As a result, $20 \mathrm{~mL}$ of additional THF was added to aid in stirring the mixture followed by the addition of $2.61 \mathrm{~g}(17.3 \mathrm{mmol})$ of $t$-butyldimethylsilyl chloride. After stirring at $\mathrm{rt}$ for $48 \mathrm{~h}$, the mixture was partitioned between $100 \mathrm{~mL}$ of saturated aqueous ammonium chloride and $100 \mathrm{~mL}$ of diethyl ether. The aqueous portion was extracted with additional diethyl ether $(3 \times 70 \mathrm{~mL})$ and the combined organic extracts were washed with brine $(2 \times 50 \mathrm{~mL})$, dried over magnesium sulfate, and concentrated in vacuo to provide approximately $8 \mathrm{~g}$ of the crude product as a yellow oil. Purification by flash chromatography (elution with $35 \% \mathrm{Et}_{2} \mathrm{O}$ in petroleum ether) afforded $6.34 \mathrm{~g}(80 \%)$ of pure $\mathbf{5 0}$ as a colorless oil. TLC $\mathrm{R}_{\mathrm{f}}=0.38\left(30 \% \mathrm{Et}_{2} \mathrm{O}\right.$ in petroleum ether). IR (film): 3483.1, 2956.3, 2858.1, 1648.8, $1471.9,1334.3,1111.4,836.5,778.6 \mathrm{~cm}^{-1} .{ }^{1} \mathrm{H} \mathrm{NMR}\left(300 \mathrm{MHz}, \mathrm{CDCl}_{3}\right) \delta 5.42(\mathrm{~s}, 1 \mathrm{H}), 5.36(\mathrm{~s}$, $1 \mathrm{H}), 4.35$ (d, $J=7.8 \mathrm{~Hz}, 1 \mathrm{H}), 4.31$ (d, $J=7.8 \mathrm{~Hz}, 1 \mathrm{H}), 3.98-3.90$ (m, $2 \mathrm{H}), 3.83-3.75$ (m, $2 \mathrm{H})$, 3.70-3.59 (m, $2 \mathrm{H}), 2.33$ (dd, $J=13.2,7.3 \mathrm{~Hz}, 1 \mathrm{H}), 1.83-1.73(\mathrm{~m}, 8 \mathrm{H}), 1.70-1.61$ (m, $8 \mathrm{H}), 0.85$ $(\mathrm{s}, 9 \mathrm{H}), 0.02(\mathrm{~s}, 6 \mathrm{H}) .{ }^{13} \mathrm{C} \mathrm{NMR}\left(75 \mathrm{MHz}, \mathrm{CDCl}_{3}\right) \delta 142.96,118.89,118.82,115.88,81.27$, 80.77, 77.52 (two carbons), 62.42, 61.52, 37.39, 37.36, 37.17, 36.94, 25.81, 23.45, 23.32, 23.22 (two carbons), 18.29, -5.38, -5.53. Anal. Calcd for $\mathrm{C}_{24} \mathrm{H}_{42} \mathrm{SiO}_{6}$ : C, 63.40; H, 9.31. Found: C, 63.21; H, 9.52. $[\alpha]_{\mathrm{D}}{ }^{24}=+$ 8.80 (c $1.95, \mathrm{CH}_{2} \mathrm{Cl}_{2}$ ).

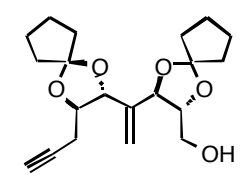

51

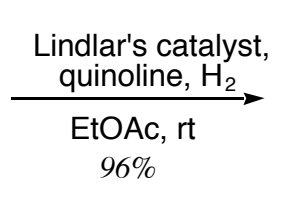

$96 \%$

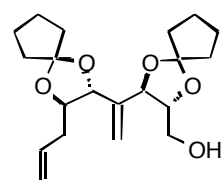

To a solution of $4.06 \mathrm{~g}(11.6 \mathrm{mmol})$ of alkyne $\mathbf{5 1} \mathrm{in} 80 \mathrm{~mL}$ of ethyl acetate at rt were successively added $2.26 \mathrm{~mL}(2.06 \mathrm{~mL}, 17.5 \mathrm{mmol})$ of quinoline and $0.50 \mathrm{~g}$ of Lindlar's catalyst $\left(5 \mathrm{wt} \%\right.$ of palladium $/ \mathrm{CaCO}_{3} / \mathrm{Pb}$ ) and the resulting mixture was cooled to $0^{\circ} \mathrm{C}$. The flask was purged with hydrogen gas using a balloon and the mixture was allowed to stir under a hydrogen atmosphere while closely monitering the progress of the reaction by TLC analysis ( $50 \%$ diethyl ether in petroleum ether). After stirring at $0^{\circ} \mathrm{C}$ for $1.5 \mathrm{~h}$, TLC analyisis showed the complete 
conversion of the starting alkyne $51\left(R_{f} \sim 0.34\right)$ to the slightly less polar alkene $\left(R_{f} \sim 0.42\right)$. The reaction mixture was immediately filtered through a pad of celite to remove the catalyst and the resulting clear filtrate was washed with ice-cold $1 \mathrm{~N} \mathrm{HCl}(3 \times 25 \mathrm{~mL})$, saturated aqueous sodium bicarbonate $(2 \times 25 \mathrm{~mL})$, and brine $(25 \mathrm{~mL})$. The solution was dried over magnesium sulfate, filtered, and concentrated in vacuo to afford $4.2 \mathrm{~g}$ of the crude product as a pale yellow oil. Flash chromatography on silica gel (elution with $45 \% \mathrm{Et}_{2} \mathrm{O}$ in petroleum ether) afforded $3.92 \mathrm{~g}$ $(96 \%)$ of pure alkene as a pale yellow oil. TLC $\mathrm{Rf}_{\mathrm{f}}=0.42\left(50 \% \mathrm{Et}_{2} \mathrm{O}\right.$ in petroleum ether). IR (film): 3473.3, 2960.0, 2874.3, 1642.6, 1433.4, 1334.5, 1204.5, 1109.1, 1037.7, 988.2, 917.1 $\mathrm{cm}^{-1}$. ${ }^{1} \mathrm{H}$ NMR $\left(300 \mathrm{MHz}, \mathrm{CDCl}_{3}\right) \delta 5.85$ (ddt, $\left.J=17.1,10.2,6.8 \mathrm{~Hz}, 1 \mathrm{H}\right), 5.46(\mathrm{~s}, 1 \mathrm{H}), 5.38$ (s, $1 \mathrm{H}), 5.14-5.07(\mathrm{~m}, 2 \mathrm{H}), 4.32(\mathrm{~d}, J=8.3 \mathrm{~Hz}, 1 \mathrm{H}), 4.08(\mathrm{~d}, J=7.8 \mathrm{~Hz}, 1 \mathrm{H}), 4.03-3.97$ (m, 2 H), $3.84(\mathrm{dd}, J=11.7,2.9 \mathrm{~Hz}, 1 \mathrm{H}), 3.67$ (dd, $J=12.2,3.9 \mathrm{~Hz}, 1 \mathrm{H}), 2.48-2.43(\mathrm{~m}, 1 \mathrm{H}), 2.31$ (app dt, $J=15.1,5.9 \mathrm{~Hz}, 1 \mathrm{H}), 2.02(\mathrm{br} \mathrm{s}, 1 \mathrm{H}), 1.87-1.73(\mathrm{~m}, 8 \mathrm{H}), 1.69-1.64(\mathrm{~m}, 8 \mathrm{H}) .{ }^{13} \mathrm{C}$ NMR $\left(75 \mathrm{MHz}, \mathrm{CDCl}_{3}\right) \delta 142.57,133.82,118.94,118.63,117.45,116.48,81.24,80.77,79.26$, 77.56, 61.50, 37.49, 37.43, 37.20 (2), 36.46, 23.45, 23.37, 23.33(2). Anal. Calcd for $\mathrm{C}_{20} \mathrm{H}_{30} \mathrm{O}_{5}$ : C, 68.55; H, 8.63. Found: C, 68.70; H, 8.78. $[\alpha]_{\mathrm{D}}{ }^{24}=+19.7$ (c $2.50, \mathrm{CH}_{2} \mathrm{Cl}_{2}$ ).
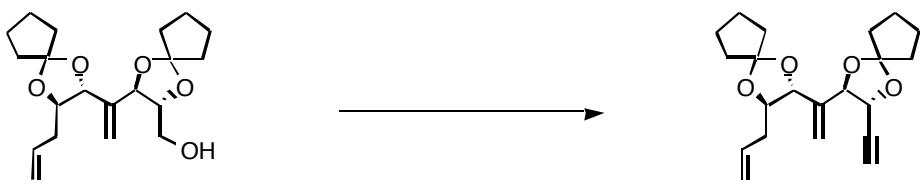

6

To a solution of $0.330 \mathrm{~g}(0.227 \mathrm{~mL}, 2.60 \mathrm{mmol})$ of oxalyl chloride in $7 \mathrm{~mL}$ of methylene chloride at $-78^{\circ} \mathrm{C}$ was slowly added $0.406 \mathrm{~g}(0.369 \mathrm{~mL}, 5.20 \mathrm{mmol})$ of anhydrous DMSO dropwise with concomitant gas evolution. After stirring at $-78^{\circ} \mathrm{C}$ for 10 minutes, a solution of $0.700 \mathrm{~g}(2.00 \mathrm{mmol})$ of the alcohol in $5 \mathrm{~mL}$ of methylene chloride was added dropwise via cannula and the resulting heterogeneous mixture was stirred for $1 \mathrm{~h}$ at $-78^{\circ} \mathrm{C}$, then $2.09 \mathrm{~mL}(12.0$ mmol) of diisopropylethylamine was added to afford a clear homogeneous solution which was stirred at $-78^{\circ} \mathrm{C}$ for $5 \mathrm{~min}$ then warmed to $-20^{\circ} \mathrm{C}$ for 45 minutes. The reaction was quenched at $20^{\circ} \mathrm{C}$ by the addition of saturated aqueous ammonium chloride $(10 \mathrm{~mL})$ followed by warming to rt. The resulting mixture was partitioned between $10 \mathrm{~mL}$ of water and $20 \mathrm{~mL}$ of methylene chloride and the aqueous portion was extracted with additional methylene chloride $(2 \times 20 \mathrm{~mL})$. 
The combined organic extracts were successively washed with $1 \mathrm{~N}$ aqueous $\mathrm{HCl}(3 \times 25 \mathrm{~mL})$, saturated aqueous sodium bicarbonate $(25 \mathrm{~mL})$, and brine $(25 \mathrm{~mL})$, then dried over anhydrous magnesium sulfate, filtered, and concentrated in vacuo to afford $0.711 \mathrm{~g}$ of crude aldehyde 52 intermediate as a clear, colorless oil. Due to the instability of $\mathbf{5 2}$, this material was not purified further but was immediately dissolved in $8 \mathrm{~mL}$ of anhydrous THF and subjected directly to the next transformation. Data for 52: IR (film): 2961.2, 2874.7, 1737.7, 1643.6, 1335.8, 1107.0, $1035.3,918.7 \mathrm{~cm}^{-1}$. ${ }^{1} \mathrm{H}$ NMR $\left(300 \mathrm{MHz}, \mathrm{CDCl}_{3}\right) \delta 9.74$ (s, $\left.1 \mathrm{H}\right), 5.84$ (ddt, $J=17.1,10.2,6.8$ Hz, $1 \mathrm{H}), 5.47$ (s, $1 \mathrm{H}), 5.37$ (s, $1 \mathrm{H}), 5.14-5.07$ (m, $2 \mathrm{H}), 4.56$ (d, $J=6.8 \mathrm{~Hz}, 1 \mathrm{H}), 4.35$ (dd, $J=$ 7.3, $1.9 \mathrm{~Hz}, 1 \mathrm{H}), 4.12$ (d, $J=7.8 \mathrm{~Hz}, 1 \mathrm{H}), 4.02-3.95(\mathrm{~m}, 1 \mathrm{H}), 2.48-2.39(\mathrm{~m}, 1 \mathrm{H}), 2.30$ (dt, $J=$ $14.2,7.3 \mathrm{~Hz}, 1 \mathrm{H}), 1.82-1.56$ (m, $14 \mathrm{H})$.

A solution of $0.745 \mathrm{~g}(5.00 \mathrm{mmol})$ of dimethyldiazomethylphosphonate in $8 \mathrm{~mL}$ of THF was transferred via cannula into $0.565 \mathrm{~mL}(0.565 \mathrm{mmol})$ of a $1.0 \mathrm{M}$ solution of sodium hexamethyldisilazide in THF at $-78^{\circ} \mathrm{C}$. The resulting bright yellow mixture was stirred at $-78^{\circ} \mathrm{C}$ for $20 \mathrm{~min}$ whereupon the solution of the previously prepared aldehyde in $8 \mathrm{~mL}$ of THF was added dropwise via cannula over $10 \mathrm{~min}$ ( $1 \mathrm{~mL}$ THF rinse). The resulting mixture was stirred at $-78^{\circ} \mathrm{C}$ for $30 \mathrm{~min}$ then warmed to $\mathrm{rt}$ and quenched with $10 \mathrm{~mL}$ of water. The layers were separated and the aqueous portion was extracted with additional diethyl ether $(3 \times 25 \mathrm{~mL})$ and the combined extracts were washed with brine $(25 \mathrm{~mL})$, dried over anhydrous magnesium, filtered, and concentrated in vacuo to afford $0.708 \mathrm{~g}$ of the crude alkyne as a yellow oil. Flash chromatography on silica gel (elution with 5\% diethyl ether in petroleum ether) provided $0.578 \mathrm{~g}$ (84\%) of pure 6 as a pale yellow oil. $\mathrm{TLC} \mathrm{R}_{\mathrm{f}}=0.28\left(5 \% \mathrm{Et}_{2} \mathrm{O}\right.$ in petroleum ether). IR (film): 3268.0, 3077.8, 2961.9, 2874.8, 2116.2, 1643.1, 1433.6, 1335.5, 1205.5, 1107.2, 1037.8, 919.5 $\mathrm{cm}^{-1} .{ }^{1} \mathrm{H}$ NMR (300 MHz, $\left.\mathrm{CDCl}_{3}\right) \delta 5.84(\mathrm{ddt}, J=17.1,10.3,6.8 \mathrm{~Hz}, 1 \mathrm{H}), 5.47$ (s, $\left.1 \mathrm{H}\right), 5.39$ (s, 1 H), 5.14-5.06 (m, 2 H), 4.46 (s, 2 H), 4.14 (d, $J=8.3$ Hz, 1 H), 3.98 (ddd, $J=11.7,7.3,4.4$ $\mathrm{Hz}, 1 \mathrm{H}), 2.53$ (s, $1 \mathrm{H}$ ), 2.42 (app dt, $J=14.6,5.9 \mathrm{~Hz}, 1 \mathrm{H}$ ), 2.30 (app dt, $J=14.6,6.8 \mathrm{~Hz}, 1 \mathrm{H}$ ), 1.98-1.76 (m, $8 \mathrm{H}), 1.74-1.61$ (m, $8 \mathrm{H}) .{ }^{13} \mathrm{C} \mathrm{NMR}\left(75 \mathrm{MHz}, \mathrm{CDCl}_{3}\right) \delta$ 141.73, 133.79, 120.31, 118.71, 117.50, 117.24, 81.27, 81.17, 80.75, 79.28, 75.04, 70.32, 37.49, 37.26, 36.63(2), 36.36, 23.80, 23.46, 23.42, 23.12. Anal. Calcd for $\mathrm{C}_{21} \mathrm{H}_{28} \mathrm{O}_{4}$ : C, 73.23; H, 8.19. Found: C, 73.40; $\mathrm{H}$, 8.33. $[\alpha]_{\mathrm{D}}{ }^{24}=+27.9\left(\mathrm{c} 1.78, \mathrm{CH}_{2} \mathrm{Cl}_{2}\right)$. 


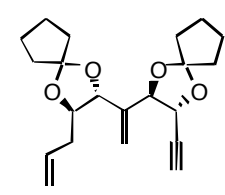

6

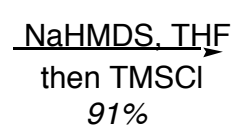

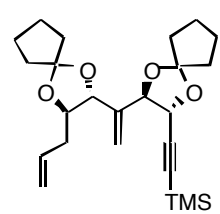

53

To a solution of $0.564 \mathrm{~g}(1.64 \mathrm{mmol})$ of alkyne 6 in $4 \mathrm{~mL}$ of THF at $-78^{\circ} \mathrm{C}$ was added $3.28 \mathrm{~mL}$ ( $3.28 \mathrm{mmol}$ ) of a $1.0 \mathrm{M}$ solution of sodium hexamethyldisilazide in THF. The resulting mixture was stirred at $-78^{\circ} \mathrm{C}$ for $45 \mathrm{~min}$, warmed to $0^{\circ} \mathrm{C}$ for $20 \mathrm{~min}$, then recooled to $-78^{\circ} \mathrm{C}$ whereupon $0.69 \mathrm{~g}(0.72 \mathrm{~mL}, 4.92 \mathrm{mmol})$ of freshly distilled trimethylsilylchloride was added. After stirring at $-78^{\circ} \mathrm{C}$ for $45 \mathrm{~min}$, the mixture was warmed to $0^{\circ} \mathrm{C}$ then rapidly quenched by pouring in $10 \mathrm{~mL}$ of saturated aqueous sodium bicarbonate all at once. Diethyl ether $(20 \mathrm{~mL})$ was added and the resulting layers were separated. The aqueous portion was extracted with additional diethyl ether $(3 \times 20 \mathrm{~mL})$ and the combined organic extracts were washed with brine $(20 \mathrm{~mL})$, dried over anhydrous magnesium, filtered, and concentrated in vacuo to afford $0.686 \mathrm{~g}$ of the crude product mixture as a golden-yellow oil. Flash chromatography on silica gel (elution with $5 \%$ diethyl ether in petroleum ether) provided $0.621 \mathrm{~g} \mathrm{(91 \% )} \mathrm{of} \mathrm{pure} 53$ as a pale yellow oil. TLC $\mathrm{Rf}_{\mathrm{f}}=0.84$ (15\% $\mathrm{Et}_{2} \mathrm{O}$ in petroleum ether). IR (film): 2960.8, 2875.0, 2176.9, 1642.0, 1432.9, 1334.8, 1105.8, 844.3, $760.3 \mathrm{~cm}^{-1}$. ${ }^{1} \mathrm{H}$ NMR $\left(300 \mathrm{MHz}, \mathrm{CDCl}_{3}\right) \delta 5.84$ (ddt, $J=17.1$, 10.2, $6.8 \mathrm{~Hz}, 1 \mathrm{H}), 5.47$ (s, $1 \mathrm{H}), 5.39$ (s, $1 \mathrm{H}), 5.14-5.06$ (m, 2 H), 4.39 (app s, $2 \mathrm{H}), 4.16$ (d, J= $8.3 \mathrm{~Hz}, 1 \mathrm{H}$ ), 3.94 (ddd, $J=11.7,7.3,4.4 \mathrm{~Hz}, 1 \mathrm{H}$ ), 2.44 (app dt, $J=14.6,8.8 \mathrm{~Hz}, 1 \mathrm{H}$ ), 2.30 (dt, $J=14.6,7.3 \mathrm{~Hz}, 1 \mathrm{H}), 2.01-1.74$ (m, $8 \mathrm{H}), 1.721 .50$ (m, $8 \mathrm{H}), 0.15$ (s, $9 \mathrm{H}) .{ }^{13} \mathrm{C} \mathrm{NMR}(75 \mathrm{MHz}$, $\left.\mathrm{CDCl}_{3}\right) \delta 142.38,133.79,120.18,118.73,117.58,116.20,101.87,92.40,81.01,80.72,79.64$, 71.39, 37.49, 37.33, 36.80, 36.71, 36.49, 23.80, 23.45(2), 23.25, -0.30. Anal. Calcd for $\mathrm{C}_{24} \mathrm{H}_{36} \mathrm{SiO}_{4}$ : C, 69.19; H, 8.71. Found: $\mathrm{C}, 69.16 ; \mathrm{H}, 8.83$. $[\alpha]_{\mathrm{D}}{ }^{24}=+43.4\left(\mathrm{c} 1.00, \mathrm{CH}_{2} \mathrm{Cl}_{2}\right)$.

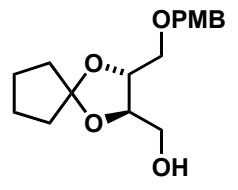

55

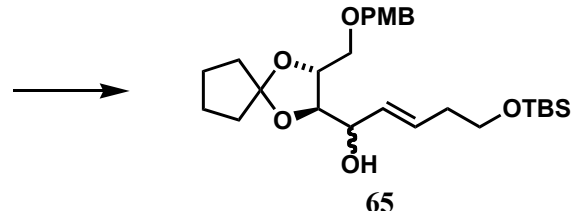

65

To a solution of oxalyl chloride $(1.50 \mathrm{~mL}, 2.18 \mathrm{~g}, 17.2 \mathrm{mmol})$ in $\mathrm{CH}_{2} \mathrm{Cl}_{2}(40 \mathrm{~mL})$ at -78 ${ }^{\circ} \mathrm{C}$ was added DMSO $(2.50 \mathrm{~mL}, 2.75 \mathrm{~g}, 35.2 \mathrm{mmol})$, stirred for $15 \mathrm{~min}$, and a solution of alcohol $55(3.264 \mathrm{~g}, 10.6 \mathrm{mmol})$ in $\mathrm{CH}_{2} \mathrm{Cl}_{2}(35 \mathrm{~mL})$ at $-78^{\circ} \mathrm{C}$ was added via cannula. After $1 \mathrm{~h}$ at -78 
${ }^{\circ} \mathrm{C}$, triethylamine $(7.4 \mathrm{~mL}, 5.4 \mathrm{~g}, 53 \mathrm{mmol})$ was added, the reaction mixture was stirred at $-78^{\circ} \mathrm{C}$ for $15 \mathrm{~min}$, warmed to room temperature, diluted with $\mathrm{CH}_{2} \mathrm{Cl}_{2}$, washed with saturated $\mathrm{NH}_{4} \mathrm{Cl}$ (2 $\mathrm{x}$ ), brine (1 x), dried over $\mathrm{MgSO}_{4}$, filtered through a pad of silica gel, and concentrated to give aldehyde 64 which was used in the next step without further purification: ${ }^{1} \mathrm{H}$ NMR $(500 \mathrm{MHz}$, $\left.\mathrm{CDCl}_{3}\right) \delta 9.75(\mathrm{~d}, J=1.7 \mathrm{~Hz}, 1 \mathrm{H}), 7.26(\mathrm{~d}, J=8.8 \mathrm{~Hz}, 2 \mathrm{H}), 6.88(\mathrm{~d}, J=8.5 \mathrm{~Hz}, 2 \mathrm{H}), 4.53$ (s, 2H), $4.51(\mathrm{~m}, 1 \mathrm{H}), 4.21(\mathrm{~m}, 1 \mathrm{H}), 4.17(\mathrm{dd}, J=7.1,1.7 \mathrm{~Hz}, 1 \mathrm{H}), 3.81(\mathrm{~s}, 3 \mathrm{H}), 3.79(\mathrm{~m}, 1 \mathrm{H}), 3.62$ (d, $J=4.9 \mathrm{~Hz}, 1 \mathrm{H}), 1.92-1.62(\mathrm{~m}, 8 \mathrm{H})$. To a solution of $\mathrm{HC} \equiv \mathrm{CCH}_{2} \mathrm{CH}_{2} \mathrm{OTBS}(4.849 \mathrm{~g}, 26.3$ $\mathrm{mmol})$ in THF $(100 \mathrm{~mL})$ at $0{ }^{\circ} \mathrm{C}$ was added $n$-BuLi $(10.5 \mathrm{~mL}, 2.5 \mathrm{M}$ in hexanes, $26.3 \mathrm{mmol})$, stirred for $15 \mathrm{~min}$, cooled to $-60^{\circ} \mathrm{C}$, and $\mathrm{ClTi}(\mathrm{O} i-\mathrm{Pr})_{3}(6.25 \mathrm{~mL}, 6.82 \mathrm{~g}, 26.2 \mathrm{mmol})$ was added. The solution was stirred at $-60^{\circ} \mathrm{C}$ for $1.5 \mathrm{~h}$, cooled to $-78^{\circ} \mathrm{C}$, and a solution of aldehyde 64 , prepared in the previous step, in THF $(80 \mathrm{~mL})$ at $-78^{\circ} \mathrm{C}$ was added via cannula. The reaction mixture was stirred at $-78^{\circ} \mathrm{C}$ for $1 \mathrm{~h}$, warmed from $-78^{\circ} \mathrm{C}$ to $-50^{\circ} \mathrm{C}$ over $1 \mathrm{~h}$, quenched with saturated $\mathrm{NH}_{4} \mathrm{Cl}$, warmed to room temperature, and diluted with ether and water. The aqueous phase was extracted with ether $(6 \mathrm{x})$ and the combined organic extracts were washed with brine (1 x), dried over $\mathrm{MgSO}_{4}$, concentrated, to give alkyne $\mathbf{5 6}$ which was used without further purification: ${ }^{1} \mathrm{H}$ NMR $\left(500 \mathrm{MHz}, \mathrm{CDCl}_{3}\right) \delta 7.26(\mathrm{~d}, J=8.8 \mathrm{~Hz}, 2 \mathrm{H}), 6.87(\mathrm{~d}, J=8.8 \mathrm{~Hz}, 2 \mathrm{H})$, 4.55-4.52 (m, 2H), $4.49(\mathrm{~m}, 1 \mathrm{H}), 3.86(\mathrm{dd}, J=7.3,4.4 \mathrm{~Hz}, 1 \mathrm{H}), 3.81-3.78(\mathrm{~m}, 3 \mathrm{H}), 3.80(\mathrm{~s}, 3 \mathrm{H})$, 3.69 (t, $J=7.3 \mathrm{~Hz}, 2 \mathrm{H}), 3.62$ (d, $J=5.1 \mathrm{~Hz}, 1 \mathrm{H}), 2.45$ (d, $J=4.6 \mathrm{~Hz}, 1 \mathrm{H}), 2.38$ (dddd, $J=7.1$, 7.1, 2.0, $2.0 \mathrm{~Hz}, 1 \mathrm{H}), 1.88-1.65(\mathrm{~m}, 8 \mathrm{H}), 0.89(\mathrm{~s}, 9 \mathrm{H}), 0.08(\mathrm{~s}, 6 \mathrm{H})$. To a solution of alkyne $\mathbf{5 6}$, prepared in the previous step, in THF $(33 \mathrm{~mL})$ at $0{ }^{\circ} \mathrm{C}$ was added Red- $\mathrm{Al} \mathrm{l}^{\mathbb{R}}(5.6 \mathrm{~mL}, 65 \% \mathrm{wt}$ in toluene, $18.7 \mathrm{mmol}$ ). The reaction mixture was warmed to room temperature, stirred for $6 \mathrm{~h}$, quenched with aqueous potassium sodium tartrate, stirred for $20 \mathrm{~min}$, and diluted with ether and water. The aqueous phase was extracted with $\mathrm{Et}_{2} \mathrm{O}(5 \mathrm{x})$ and the combined organic extracts were washed with brine $(1 \mathrm{x})$, dried over $\mathrm{MgSO}_{4}$, and concentrated. Purification by flash column chromatography on silica gel ( $20 \%$ to $30 \%$ to $50 \%$ EtOAc in petroleum ether) gave alkene $\mathbf{6 5}$ (2.636 g, 51\%) and recovered alcohol 55 (747 mg, 23\%) as colorless oils. Data for 65: $\mathrm{R}_{f}=0.29$ (20\% EtOAc in petroleum ether); ${ }^{1} \mathrm{H}$ NMR (500 MHz, $\left.\mathrm{CDCl}_{3}\right) \delta 7.25(\mathrm{~d}, J=8.8 \mathrm{~Hz}, 2 \mathrm{H}), 6.87$ (d, $J=8.8 \mathrm{~Hz}, 2 \mathrm{H}$ ), 5.76 (dddd, $J=13.9,6.8,6.8,1.2 \mathrm{~Hz}, 1 \mathrm{H}$ ), 5.51 (ddd, $J=15.4,6.1,1.2 \mathrm{~Hz}$, 1H), 4.51 (s, 2H), $4.18(\mathrm{~m}, 1 \mathrm{H}), 4.07$ (ddd, $J=7.3,5.4,5.4 \mathrm{~Hz}, 1 \mathrm{H}), 3.80$ (s, 3H), 3.70 (dd, $J=$ 7.6, $5.6 \mathrm{~Hz}, 1 \mathrm{H}), 3.62$ (t, $J=6.8 \mathrm{~Hz}, 2 \mathrm{H}), 3.58$ (dd, $J=10.0,5.6 \mathrm{~Hz}, 1 \mathrm{H}), 3.51$ (dd, $J=10.0,5.1$ $\mathrm{Hz}, 1 \mathrm{H}), 2.57$ (d, $J=2.9 \mathrm{~Hz}, 1 \mathrm{H}), 2.25(\mathrm{q} b r, J=6.8 \mathrm{~Hz}, 2 \mathrm{H}), 1.88-1.62(\mathrm{~m}, 8 \mathrm{H}), 0.89$ (s, 9H), 
0.04 (s, 6H); ${ }^{13} \mathrm{C}$ NMR (101 MHz, $\left.\mathrm{CDCl}_{3}\right) \delta 159.3,130.1,129.8,129.7,129.4,119.3,113.8$, 81.2, 76.7, 73.2, 72.2, 70.4, 68.2, 55.2, 37.2, 37.1, 36.0, 25.9, 23.6, 23.3, 18.3, -5.3; IR (neat) 3458 (br), 2955, 1614, 1515, 1250, $1102 \mathrm{~cm}^{-1}$; MALDIMS $m / z 515.3[\mathrm{M}+\mathrm{Na}]^{+}$; optical rotation $[\alpha]_{\mathrm{D}}{ }^{27}+9.5^{\circ}\left(c 1.0, \mathrm{CH}_{2} \mathrm{Cl}_{2}\right)$. Anal. Calcd for $\mathrm{C}_{27} \mathrm{H}_{44} \mathrm{O}_{6} \mathrm{Si}: \mathrm{C}, 65.82 ; \mathrm{H}, 9.00$. Found: $\mathrm{C}, 65.66 ; \mathrm{H}$, 8.87.
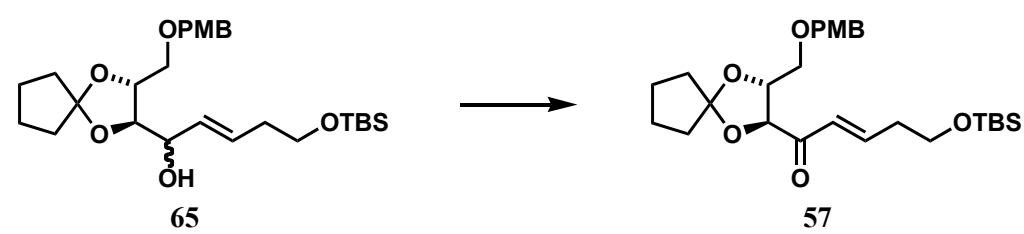

To a solution of alcohol $65(3.038 \mathrm{~g}, 6.17 \mathrm{mmol})$ in $\mathrm{CH}_{2} \mathrm{Cl}_{2}(40 \mathrm{~mL})$ at $0{ }^{\circ} \mathrm{C}$ was added $\mathrm{NaHCO}_{3}(3.668 \mathrm{~g}, 43.7 \mathrm{mmol})$ and Dess-Martin reagent (3.559 g, $\left.8.39 \mathrm{mmol}\right)$. The reaction mixture was warmed to room temperature, stirred for $2 \mathrm{~h}$, quenched with saturated $\mathrm{Na}_{2} \mathrm{SO}_{3}$, stirred for $15 \mathrm{~min}$, and diluted with water. The aqueous phase was extracted with $\mathrm{CH}_{2} \mathrm{Cl}_{2}(5 \mathrm{x})$ and the combined organic extracts were washed with brine $(1 \mathrm{x})$, dried over $\mathrm{MgSO}_{4}$, and concentrated. Purification by flash column chromatography on silica gel (5\% to $10 \%$ to $15 \%$ EtOAc in petroleum ether) gave ketone $57(2.613 \mathrm{~g}, 86 \%)$ as a colorless oil: $\mathrm{R}_{f}=0.20(10 \%$ EtOAc in petroleum ether); ${ }^{1} \mathrm{H} \mathrm{NMR}\left(400 \mathrm{MHz}, \mathrm{CDCl}_{3}\right) \delta 7.27(\mathrm{~d}, J=8.4 \mathrm{~Hz}, 2 \mathrm{H}), 7.05$ (ddd, $J$ $=15.9,7.2,7.2 \mathrm{~Hz}, 1 \mathrm{H}), 6.87(\mathrm{~d}, J=8.7 \mathrm{~Hz}, 2 \mathrm{H}), 6.58(\mathrm{ddd}, J=15.9,1.5,1.5 \mathrm{~Hz}, 1 \mathrm{H}), 4.54(\mathrm{~s}$, 2H), $4.30(\mathrm{~d}, J=7.0 \mathrm{~Hz}, 1 \mathrm{H}), 4.23(\mathrm{ddd}, J=7.0,5.8,3.5 \mathrm{~Hz}, 1 \mathrm{H}), 3.80$ (s, 3H), 3.73 (t, $J=6.4$ $\mathrm{Hz}, 2 \mathrm{H}), 3.70(\mathrm{dd}, J=10.7,3.5 \mathrm{~Hz}, 1 \mathrm{H}), 3.60(\mathrm{dd}, J=10.5,5.6 \mathrm{~Hz}, 1 \mathrm{H}), 2.44$ (ddd, $J=13.6,6.6$, $1.5 \mathrm{~Hz}, 2 \mathrm{H}), 1.91-1.67(\mathrm{~m}, 8 \mathrm{H}), 0.88(\mathrm{~s}, 9 \mathrm{H}), 0.04(\mathrm{~s}, 6 \mathrm{H}) ;{ }^{13} \mathrm{C} \mathrm{NMR}\left(101 \mathrm{MHz}, \mathrm{CDCl}_{3}\right) \delta 197.7$, 159.2, 147.1, 130.0, 129.4, 126.5, 120.9, 113.8, 80.8, 77.5, 73.2, 69.9, 61.4, 55.3, 36.8, 36.7, 36.2, 25.9, 23.7, 23.3, 18.3, -5.3; IR (neat) 2959, 1691, 1252, 1103, $836 \mathrm{~cm}^{-1}$; EIMS m/z 277 (1), 213 (1), 145 (1), 137 (1), 121 (100); HREIMS calcd for $\mathrm{C}_{27} \mathrm{H}_{42} \mathrm{O}_{6} \mathrm{Si}$ 490.2751, found 490.2751; optical rotation $[\alpha]_{\mathrm{D}}{ }^{27}+6.0^{\circ}\left(c\right.$ 1.0, $\left.\mathrm{CH}_{2} \mathrm{Cl}_{2}\right)$. Anal. Calcd for $\mathrm{C}_{27} \mathrm{H}_{42} \mathrm{O}_{6} \mathrm{Si}: \mathrm{C}, 66.09 ; \mathrm{H}, 8.63$. Found: C, 66.40; H, 8.62.
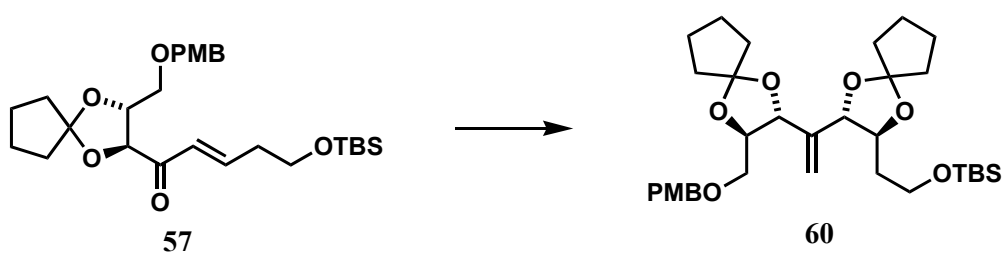
To a mixture of $\mathrm{K}_{3} \mathrm{Fe}(\mathrm{CN})_{6}(17.96 \mathrm{~g}, 54.5 \mathrm{mmol}), \mathrm{K}_{2} \mathrm{CO}_{3}(7.57 \mathrm{~g}, 54.8 \mathrm{mmol}), \mathrm{NaHCO}_{3}$ (4.62 g, $55.0 \mathrm{mmol}$ ), methanesulfonamide (1.720 g, $18.1 \mathrm{mmol}$ ), and (DHQ)2-PHAL (369 mg, $0.47 \mathrm{mmol})$ at room temperature was added water $(85 \mathrm{~mL})$ and tert-butyl alcohol $(45 \mathrm{~mL})$. The reaction mixture was cooled to $0{ }^{\circ} \mathrm{C}, \mathrm{K}_{2} \mathrm{OsO}_{4} \cdot 2 \mathrm{H}_{2} \mathrm{O}(171 \mathrm{mg}, 0.46 \mathrm{mmol})$ was added followed by a solution of alkene $57(8.871 \mathrm{~g}, 18.1 \mathrm{mmol})$ in tert-butyl alcohol $(40 \mathrm{~mL})$. The reaction mixture was stirred at $0{ }^{\circ} \mathrm{C}$ for $22 \mathrm{~h}$, quenched with $\mathrm{Na}_{2} \mathrm{SO}_{3}(80 \mathrm{~g})$, warmed to room temperature, stirred for $1 \mathrm{~h}$, and diluted with EtOAc and water. The aqueous phase was extracted with EtOAc $(4 \mathrm{x})$ and the combined organic extracts were washed with $2 \mathrm{M} \mathrm{NaOH}(1 \mathrm{x})$, brine (1 $\mathrm{x})$, dried over $\mathrm{MgSO}_{4}$, and concentrated to give diol $\mathbf{5 8}$ which was used in the next step without further purification: $\mathrm{R}_{f}=0.46$ (30\% EtOAc in petroleum ether); ${ }^{1} \mathrm{H} \mathrm{NMR}\left(500 \mathrm{MHz}, \mathrm{CDCl}_{3}\right) \delta 7.27$ (d, $J$ $=7.8 \mathrm{~Hz}, 2 \mathrm{H}), 6.87(\mathrm{~d}, J=8.5 \mathrm{~Hz}, 2 \mathrm{H}), 4.55(\mathrm{~s}, 2 \mathrm{H}), 4.52(\mathrm{~d} \mathrm{br}, J=7.3 \mathrm{~Hz}, 1 \mathrm{H}), 4.48(\mathrm{~d}, J=6.8$ $\mathrm{Hz}, 1 \mathrm{H}$ ), 4.34 (ddd, $J=5.9,5.9,3.2 \mathrm{~Hz}, 1 \mathrm{H}$ ), 3.95-3.85 (m, 3H), 3.80 (s, $3 \mathrm{H}), 3.75$ (dd, $J=11.0$, $3.2 \mathrm{~Hz}, 1 \mathrm{H}), 3.62$ (dd, $J=10.8,5.9 \mathrm{~Hz}, 1 \mathrm{H}), 3.45$ (d, $J=6.8 \mathrm{~Hz}, 1 \mathrm{H}), 3.14(\mathrm{~d}, J=4.9 \mathrm{~Hz}, 1 \mathrm{H})$, 2.03-1.66 (m, 10H), $0.89(\mathrm{~s}, 9 \mathrm{H}), 0.08(\mathrm{~s}, 6 \mathrm{H})$. To a solution of diol 58, prepared in the previous step, and 1,1-dimethoxycyclopentane $(25 \mathrm{~mL})$ in $\mathrm{CH}_{2} \mathrm{Cl}_{2}(190 \mathrm{~mL})$ at $0{ }^{\circ} \mathrm{C}$ was added $\mathrm{TsOH} \cdot \mathrm{H}_{2} \mathrm{O}$ $(562 \mathrm{mg}, 2.95 \mathrm{mmol})$. The reaction mixture was stirred at $0{ }^{\circ} \mathrm{C}$ for $2 \mathrm{~h}$, diluted with ether, washed with saturated $\mathrm{NaHCO}_{3}(1 \mathrm{x})$, brine $(1 \mathrm{x})$, dried over $\mathrm{MgSO}_{4}$, and concentrated to give ketal 59 which was used in the next step without further purification: $\mathrm{R}_{f}=0.68$ (30\% EtOAc in petroleum ether); ${ }^{1} \mathrm{H}$ NMR (500 MHz, $\left.\mathrm{CDCl}_{3}\right) \delta 7.27$ (d, $\left.J=8.8 \mathrm{~Hz}, 2 \mathrm{H}\right), 6.87$ (d, $\left.J=8.5 \mathrm{~Hz}, 2 \mathrm{H}\right), 4.57$ $4.51(\mathrm{~m}, 3 \mathrm{H}), 4.41$ (d, $J=7.1 \mathrm{~Hz}, 1 \mathrm{H}), 4.26$ (ddd, $J=9.3,6.1,3.2 \mathrm{~Hz}, 1 \mathrm{H}), 4.18$ (ddd, $J=8.8$, 7.1, $3.7 \mathrm{~Hz}, 1 \mathrm{H}), 3.80(\mathrm{~s}, 3 \mathrm{H}), 3.79-3.72(\mathrm{~m}, 3 \mathrm{H}), 3.62(\mathrm{dd}, J=10.7,6.1 \mathrm{~Hz}, 1 \mathrm{H}), 2.07-1.63(\mathrm{~m}$, $20 \mathrm{H}), 0.87(\mathrm{~s}, 9 \mathrm{H}), 0.04(\mathrm{~s}, 6 \mathrm{H})$. To a suspension of methyltriphenylphosphonium bromide (13.08 g, $36.6 \mathrm{mmol})$ in THF $(150 \mathrm{~mL})$ at $0{ }^{\circ} \mathrm{C}$ was added NaHMDS $(37 \mathrm{~mL}, 1.0 \mathrm{M}$ in THF, 37 mmol), stirred at $0{ }^{\circ} \mathrm{C}$ for $15 \mathrm{~min}$, warmed to room temperature, stirred for $1 \mathrm{~h}$, cooled to $0{ }^{\circ} \mathrm{C}$, and a solution of ketone $\mathbf{5 9}$, prepared in the previous step, in THF $(150 \mathrm{~mL})$ at $0{ }^{\circ} \mathrm{C}$ was added via cannula. The reaction mixture was stirred at $0{ }^{\circ} \mathrm{C}$ for $11 \mathrm{~h}$ and diluted with ether and water. The aqueous phase was extracted with ether $(3 \mathrm{x})$ and the combined organic extracts were washed with brine $(1 \mathrm{x})$, dried over $\mathrm{MgSO}_{4}$, and concentrated. Purification by flash column chromatography on silica gel ( $5 \%$ to $10 \%$ EtOAc in petroleum ether) gave alkene $60(6.351 \mathrm{~g}$, $60 \%)$ as a colorless oil: $\mathrm{R}_{f}=0.38\left(10 \%\right.$ EtOAc in petroleum ether); ${ }^{1} \mathrm{H}$ NMR (400 MHz, $\mathrm{CDCl}_{3}$ ) $\delta 7.26(\mathrm{~d}, J=8.2 \mathrm{~Hz}, 2 \mathrm{H}), 6.86(\mathrm{~d}, J=8.5 \mathrm{~Hz}, 2 \mathrm{H}), 5.34(\mathrm{~s}, 2 \mathrm{H}), 4.55-4.49$ (m, 2H), 4.25 (d, $J=$ 
$7.9 \mathrm{~Hz}, 1 \mathrm{H}), 4.11(\mathrm{~d}, J=8.1 \mathrm{~Hz}, 1 \mathrm{H}), 4.03(\mathrm{ddd}, J=9.0,6.4,2.3 \mathrm{~Hz}, 1 \mathrm{H}), 3.89$ (ddd, $J=8.9,8.9$, $2.6 \mathrm{~Hz}, 1 \mathrm{H}), 3.80(\mathrm{~s}, 3 \mathrm{H}), 3.78-3.66(\mathrm{~m}, 3 \mathrm{H}), 3.50(\mathrm{dd}, J=10.8,6.6 \mathrm{~Hz}, 1 \mathrm{H}), 1.97-1.56(\mathrm{~m}$, 18H), 0.88 (s, 9H), 0.042 (s, 3H), 0.038 (s, 3H); ${ }^{13} \mathrm{C}$ NMR (101 MHz, $\left.\mathrm{CDCl}_{3}\right) \delta$ 159.2, 143.4, 130.2, 129.3, 119.4, 118.6, 116.5, 113.7, 80.9, 80.6, 77.6, 77.2, 73.1, 69.4, 60.1, 55.2, 37.5, 37.4, 37.1 (2 carbons), 35.3, 25.9, 23.6, 23.4, 23.3 (2 carbons), 18.3, -5.3, -5.4; IR (neat) 2949, 1614, 1510, 1334, $1103 \mathrm{~cm}^{-1}$; MALDIMS $m / z 611.3[\mathrm{M}+\mathrm{Na}]^{+}$; optical rotation $[\alpha]_{\mathrm{D}}{ }^{25}-5.9^{\circ}(c 1.0$, $\mathrm{CH}_{2} \mathrm{Cl}_{2}$ ). Anal. Calcd for $\mathrm{C}_{33} \mathrm{H}_{52} \mathrm{O}_{7} \mathrm{Si}$ : C, 67.31; H, 8.90. Found: C, 67.15; H, 8.70.
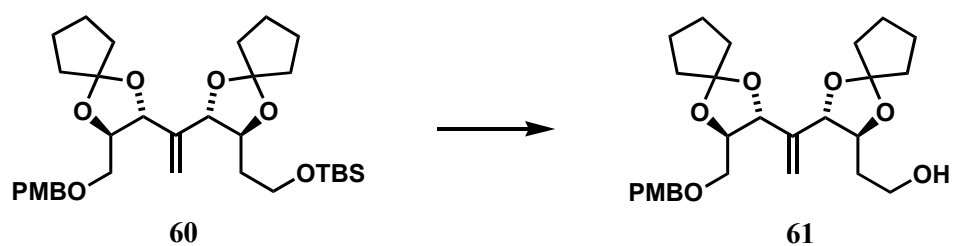

To a solution of ether $60(7.987 \mathrm{~g}, 13.6 \mathrm{mmol})$ in THF $(90 \mathrm{~mL})$ at room temperature was added TBAF (20.4 mL, $1 \mathrm{M}$ in THF, $20.4 \mathrm{mmol}$ ). The reaction mixture was stirred for $24 \mathrm{~h}$, and diluted with ether and water. The aqueous phase was extracted with ether $(4 \mathrm{x})$ and the combined organic extracts were washed with brine $(1 \mathrm{x})$, dried over $\mathrm{MgSO}_{4}$, and concentrated. Purification by flash column chromatography on silica gel (30\% to 50\% EtOAc in petroleum ether) gave alcohol 61 (5.024 g, 78\%) as a colorless oil: $\mathrm{R}_{f}=0.38\left(50 \%\right.$ EtOAc in petroleum ether); ${ }^{1} \mathrm{H}$ NMR $\left(400 \mathrm{MHz}, \mathrm{CDCl}_{3}\right) \delta 7.25(\mathrm{~d}, J=8.7 \mathrm{~Hz}, 2 \mathrm{H}), 6.86(\mathrm{~d}, J=8.7 \mathrm{~Hz}, 2 \mathrm{H}), 5.38(\mathrm{~s}, 1 \mathrm{H}), 5.36(\mathrm{~s}$, $1 \mathrm{H}), 4.51(\mathrm{~s}, 2 \mathrm{H}), 4.27$ (d, $J=8.1 \mathrm{~Hz}, 1 \mathrm{H}), 4.15(\mathrm{~d}, J=8.2 \mathrm{~Hz}, 1 \mathrm{H}), 4.02(\mathrm{ddd}, J=8.2,6.3,2.7$ $\mathrm{Hz}, 1 \mathrm{H}), 3.91$ (ddd, $J=8.4,8.4,3.4 \mathrm{~Hz}, 1 \mathrm{H}), 3.79$ (s, 3H), 3.78-3.75 (m, 2H), 3.66 (dd, $J=10.7$, $2.7 \mathrm{~Hz}, 1 \mathrm{H}), 3.50(\mathrm{dd}, J=10.8,6.3 \mathrm{~Hz}, 1 \mathrm{H}), 2.44(\mathrm{t}, J=5.6 \mathrm{~Hz}, 2 \mathrm{H}), 1.99-1.59(\mathrm{~m}, 17 \mathrm{H}) ;{ }^{13} \mathrm{C}$ NMR $\left(101 \mathrm{MHz}, \mathrm{CDCl}_{3}\right) \delta 159.1,143.0,130.1,129.35,129.30,119.5,118.9,117.2,113.7,80.9$, 80.32, 80.30, 77.2, 73.1, 69.1, 60.8, 55.2, 37.5, 37.4, 37.1, 34.0, 23.5, 23.4, 23.2 (2 carbons); IR (neat) 3486 (br), 2951, 1611, 1516, $1108 \mathrm{~cm}^{-1}$; MALDIMS m/z $497.3[\mathrm{M}+\mathrm{Na}]^{+}$; optical rotation $[\alpha]_{\mathrm{D}}{ }^{26}+4.4^{\mathrm{o}}\left(c \mathrm{1.0}, \mathrm{CH}_{2} \mathrm{Cl}_{2}\right)$; Anal. Calcd for $\mathrm{C}_{27} \mathrm{H}_{38} \mathrm{O}_{7}$ : C, 68.33; H, 8.07. Found: $\mathrm{C}, 68.17 ; \mathrm{H}$, 7.90 . 


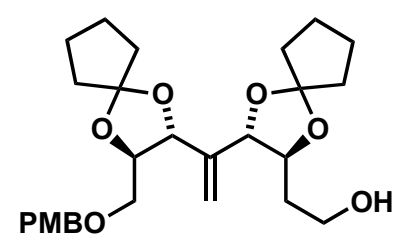

61

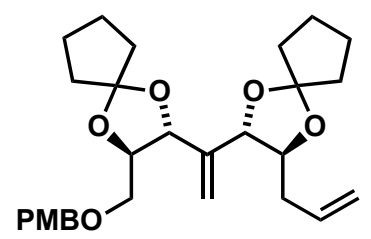

62

To a solution of oxalyl chloride $(1.50 \mathrm{~mL}, 2.18 \mathrm{~g}, 17.2 \mathrm{mmol})$ in $\mathrm{CH}_{2} \mathrm{Cl}_{2}(50 \mathrm{~mL})$ at -78 ${ }^{\circ} \mathrm{C}$ was added DMSO (2.45 mL, $\left.2.70 \mathrm{~g}, 34.5 \mathrm{mmol}\right)$, stirred for $15 \mathrm{~min}$, and a solution of alcohol 61 (5.083 g, $10.7 \mathrm{mmol})$ in $\mathrm{CH}_{2} \mathrm{Cl}_{2}(50 \mathrm{~mL})$ at $-78^{\circ} \mathrm{C}$ was added via cannula. After $1 \mathrm{~h}$ at -78 ${ }^{\circ} \mathrm{C}$, triethylamine $(7.5 \mathrm{~mL}, 5.4 \mathrm{~g}, 54 \mathrm{mmol})$ was added, the reaction mixture was stirred at $-78^{\circ} \mathrm{C}$ for $15 \mathrm{~min}$, warmed to room temperature, diluted with $\mathrm{CH}_{2} \mathrm{Cl}_{2}$, washed with saturated $\mathrm{NH}_{4} \mathrm{Cl}$ (2 $\mathrm{x})$, brine $(1 \mathrm{x})$, dried over $\mathrm{MgSO}_{4}$, filtered through a pad of silica gel, and concentrated to give the aldehyde which was used in the next step without further purification: $\mathrm{R}_{f}=0.32(30 \%$ EtOAc in petroleum ether); ${ }^{1} \mathrm{H}$ NMR $\left(500 \mathrm{MHz}, \mathrm{CDCl}_{3}\right) \delta 9.78(\mathrm{dd}, J=2.7,1.6 \mathrm{~Hz}, 1 \mathrm{H}), 7.26(\mathrm{~d}, J=8.7$ $\mathrm{Hz}, 2 \mathrm{H}), 6.87$ (d, $J=8.8 \mathrm{~Hz}, 2 \mathrm{H}), 5.43$ (s, 1H), 5.32 (s, 1H), 4.54-4.49 (m, 2H), 4.30 (d, J=8.2 Hz, 1H), 4.20 (ddd, $J=8.2,8.2,3.2 \mathrm{~Hz}, 1 \mathrm{H}), 4.16$ (d, $J=8.1 \mathrm{~Hz}, 1 \mathrm{H}), 3.98$ (ddd, $J=8.6,6.0,2.7$ $\mathrm{Hz}, 1 \mathrm{H}), 3.80$ (s, 3H), 3.64 (dd, $J=10.7,2.7 \mathrm{~Hz}, 1 \mathrm{H}), 3.50(\mathrm{dd}, J=10.8,6.0 \mathrm{~Hz}, 1 \mathrm{H}), 2.86$ (ddd, $J=16.6,3.1,1.5 \mathrm{~Hz}, 1 \mathrm{H}), 2.61(\mathrm{ddd}, J=16.6,8.2,2.6 \mathrm{~Hz}, 1 \mathrm{H}), 1.92-1.61$ (m, 16H). To a suspension of methyltriphenylphosphonium bromide $(6.00 \mathrm{~g}, 16.8 \mathrm{mmol})$ in THF $(65 \mathrm{~mL})$ at 0 ${ }^{\circ} \mathrm{C}$ was added $n$-BuLi $(6.70 \mathrm{~mL}, 2.5 \mathrm{M}$ in hexanes, $16.8 \mathrm{mmol})$. The solution was stirred at $0{ }^{\circ} \mathrm{C}$ for $30 \mathrm{~min}$ and a solution of the aldehyde, prepared in the previous step, in THF $(65 \mathrm{~mL})$ at room temperature was added via cannula. The reaction mixture was warmed to room temperature over $1 \mathrm{~h}$, stirred at room temperature for $14 \mathrm{~h}$, and diluted with ether and water. The aqueous phase was extracted with ether $(5 \mathrm{x})$ and the combined organic extracts were washed with brine $(1 \mathrm{x})$, dried over $\mathrm{MgSO}_{4}$, and concentrated. Purification by flash column chromatography on silica gel (5\% to $10 \%$ to $20 \%$ EtOAc in petroleum ether) gave alkene 62 (3.990 g, 79\%) as a colorless oil: $\mathrm{R}_{f}=0.55\left(20 \%\right.$ EtOAc in petroleum ether); ${ }^{1} \mathrm{H}$ NMR $\left(400 \mathrm{MHz}, \mathrm{CDCl}_{3}\right) \delta 7.26(\mathrm{~d}, J=8.2 \mathrm{~Hz}$, 2H), $6.86(\mathrm{~d}, J=8.7 \mathrm{~Hz}, 2 \mathrm{H}), 5.86$ (dddd, J =17.1, 13.6, 10.2, $6.9 \mathrm{~Hz}, 1 \mathrm{H}), 5.36$ (s, 1H), 5.34 (s, 1H), $5.11(\mathrm{dm}, \mathrm{J}=17.2 \mathrm{~Hz}, 1 \mathrm{H}), 5.08(\mathrm{dm}, \mathrm{J}=10.2 \mathrm{~Hz}, 1 \mathrm{H}), 4.55-4.49(\mathrm{~m}, 2 \mathrm{H}), 4.27$ (d, J = 7.9 $\mathrm{Hz}, 1 \mathrm{H}), 4.15$ (d, J = 7.9 Hz, 1H), 4.02 (ddd, J = 8.1, 6.4, 2.6 Hz, 1H), 3.85 (ddd, J = 7.9, 7.9, 3.8 Hz, 1H), 3.80 (s, 3H), 3.69 (dd, J = 10.7, 2.8 Hz, 1H), 3.50 (dd, J = 10.7, 6.6 Hz, 1H), 2.49 (m, 1H), $2.26(\mathrm{ddd}, \mathrm{J}=14.8,7.5,7.5 \mathrm{~Hz}, 1 \mathrm{H}), 1.94-1.56(\mathrm{~m}, 16 \mathrm{H}) ;{ }^{13} \mathrm{C} \mathrm{NMR}\left(101 \mathrm{MHz}, \mathrm{CDCl}_{3}\right) \delta$ $159.4,143.7,134.5,130.4,129.6,119.7,119.0,117.5,116.9,113.9,80.9,80.7,80.3,77.4,73.3$, 
69.6, 55.5, 37.8, 37.7, 37.41, 37.38, 36.5, 23.8, 23.7, 23.6 (2 carbons); IR (neat) 2959, 1614, 1515, $1103 \mathrm{~cm}^{-1}$; EIMS m/z 137 (2), 123 (2), 122 (4), 121 (100); HREIMS calcd for $\mathrm{C}_{28} \mathrm{H}_{38} \mathrm{O}_{6}$ 470.2663, found 470.2668; optical rotation $[\alpha]_{\mathrm{D}}^{24}+0.5^{\circ}\left(c 1.0, \mathrm{CH}_{2} \mathrm{Cl}_{2}\right)$. Anal. Calcd for $\mathrm{C}_{28} \mathrm{H}_{38} \mathrm{O}_{6}$ : C, 71.46; H, 8.14. Found: C, 71.65; H, 7.98.
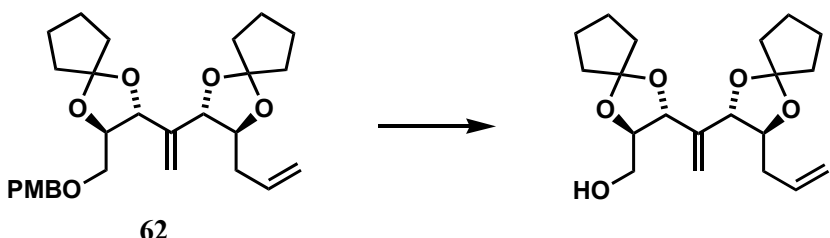

To a solution of ether $62(3.990 \mathrm{~g}, 8.48 \mathrm{mmol})$ in $\mathrm{CH}_{2} \mathrm{Cl}_{2}(55 \mathrm{~mL})$ and water $(20 \mathrm{~mL})$ at room temperature was added DDQ $(2.359 \mathrm{~g}, 10.4 \mathrm{mmol})$. The reaction mixture was stirred at room temperature for $2 \mathrm{~h}$ and diluted with ether, water, and saturated $\mathrm{NaHCO}_{3}$. The aqueous phase was extracted with ether $(4 \mathrm{x})$ and the combined organic extracts were washed with brine (1 x), dried over $\mathrm{MgSO}_{4}$, and concentrated. Purification by flash column chromatography on silica gel $\left(0 \%\right.$ to $50 \%$ EtOAc in $\left.\mathrm{CH}_{2} \mathrm{Cl}_{2}\right)$ gave the corresponding alcohol $(2.918 \mathrm{~g}, 98 \%)$ as a colorless oil: $\mathrm{R}_{f}=0.32\left(30 \%\right.$ EtOAc in petroleum ether); ${ }^{1} \mathrm{H}$ NMR $\left(500 \mathrm{MHz}, \mathrm{CDCl}_{3}\right) \delta 5.86$ (dddd, $J=17.1,13.7,10.3,7.0 \mathrm{~Hz}, 1 \mathrm{H}), 5.51(\mathrm{~s}, 1 \mathrm{H}), 5.36(\mathrm{~s}, 1 \mathrm{H}), 5.15-5.09(\mathrm{~m}, 2 \mathrm{H}), 4.27$ (d, $J$ $=7.2 \mathrm{~Hz}, 1 \mathrm{H}), 4.19(\mathrm{~d}, J=8.2 \mathrm{~Hz}, 1 \mathrm{H}), 3.86(\mathrm{ddd}, J=7.7,7.7,3.7 \mathrm{~Hz}, 1 \mathrm{H}), 3.83-3.75(\mathrm{~m}, 3 \mathrm{H})$, 2.68 (s br, 1H), 2.48 (dm, $J=14.8 \mathrm{~Hz}, 1 \mathrm{H}), 2.28$ (ddd, $J=14.8,7.3,7.3 \mathrm{~Hz}, 1 \mathrm{H}), 1.90-1.61$ (m, $16 \mathrm{H}) ;{ }^{13} \mathrm{C}$ NMR $\left(126 \mathrm{MHz}, \mathrm{CDCl}_{3}\right) \delta 142.7,133.8,119.1,118.7,117.60,117.59,83.2,81.8$, 79.3, 77.1, 62.0, 37.4 (2 carbons), 37.3, 37.1, 36.0, 23.43, 23.39, 23.37, 23.2; IR (neat) 3484 (br), 2959, 1642, $1107 \mathrm{~cm}^{-1}$; EIMS m/z 277350 (13), 322 (17), 321 (37), 225 (15); HREIMS calcd for $\mathrm{C}_{20} \mathrm{H}_{30} \mathrm{O}_{5} 350.2093$, found 350.2090; optical rotation $[\alpha]_{\mathrm{D}}{ }^{24}-22^{\circ}\left(c 1.0, \mathrm{CH}_{2} \mathrm{Cl}_{2}\right)$. Anal. Calcd for $\mathrm{C}_{20} \mathrm{H}_{30} \mathrm{O}_{5}$ : C, 68.54; H, 8.63. Found: C, 68.70; H, 8.66.
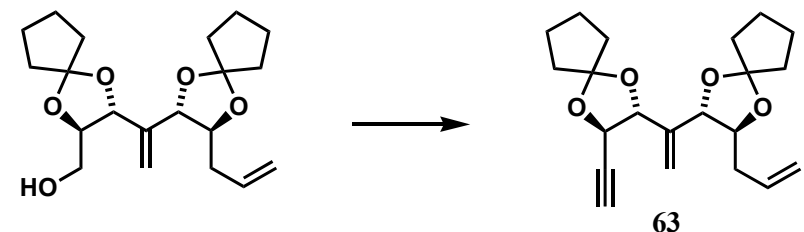

To a solution of oxalyl chloride ( $40 \mu \mathrm{L}, 58 \mathrm{mg}, 0.46 \mathrm{mmol})$ in $\mathrm{CH}_{2} \mathrm{Cl}_{2}(2 \mathrm{~mL})$ at $-78^{\circ} \mathrm{C}$ was added DMSO ( $65 \mu \mathrm{L}, 72 \mathrm{mg}, 0.92 \mathrm{mmol})$, stirred for $15 \mathrm{~min}$, and a solution of the alcohol 
(101 mg, $0.29 \mathrm{mmol})$ in $\mathrm{CH}_{2} \mathrm{Cl}_{2}(2 \mathrm{~mL})$ at $-78^{\circ} \mathrm{C}$ was added via cannula. After $1 \mathrm{~h}$ at $-78^{\circ} \mathrm{C}$, triethylamine $(200 \mu \mathrm{L}, 145 \mathrm{mg}, 1.4 \mathrm{mmol})$ was added, the reaction mixture was stirred at $-78^{\circ} \mathrm{C}$ for $15 \mathrm{~min}$, warmed to $0{ }^{\circ} \mathrm{C}$, diluted with ether, washed with saturated $\mathrm{NH}_{4} \mathrm{Cl}(2 \mathrm{x})$, brine $(1 \mathrm{x})$, dried over $\mathrm{MgSO}_{4}$, filtered through a pad of silica gel, and concentrated to give the aldehyde which was used in the next step without further purification: $\mathrm{R}_{f}=0.19(20 \%$ EtOAc in petroleum ether); ${ }^{1} \mathrm{H}$ NMR (400 MHz, $\left.\mathrm{CDCl}_{3}\right) \delta 9.72(\mathrm{~d}, \mathrm{~J}=2.0 \mathrm{~Hz}, 1 \mathrm{H}), 5.87$ (dddd, $J=16.9,13.6,10.2$, $6.9 \mathrm{~Hz}, 1 \mathrm{H}), 5.51(\mathrm{~s}, 1 \mathrm{H}), 5.32(\mathrm{~s}, 1 \mathrm{H}), 5.16-5.10(\mathrm{~m}, 2 \mathrm{H}), 4.66(\mathrm{~d}, J=6.6 \mathrm{~Hz}, 1 \mathrm{H}), 4.23(\mathrm{dd}, J=$ 6.7, $2.0 \mathrm{~Hz}, 1 \mathrm{H}), 4.20(\mathrm{~d}, J=8.2 \mathrm{~Hz}, 1 \mathrm{H}), 3.86(\mathrm{ddd}, J=7.6,7.6,3.8 \mathrm{~Hz}, 1 \mathrm{H}), 2.46(\mathrm{dm}, J=14.8$ $\mathrm{Hz}, 1 \mathrm{H}), 2.28(\mathrm{ddd}, J=14.6,6.9,6.9 \mathrm{~Hz}, 1 \mathrm{H}), 2.00-1.62(\mathrm{~m}, 16 \mathrm{H})$. To a solution of $(\mathrm{MeO})_{2} \mathrm{POC}\left(=\mathrm{N}_{2}\right) \mathrm{COMe}(277 \mathrm{mg}, 1.44 \mathrm{mmol})$ in $\mathrm{MeOH}(1 \mathrm{~mL})$ at $0{ }^{\circ} \mathrm{C}$ was added $\mathrm{K}_{2} \mathrm{CO}_{3}(204$ $\mathrm{mg}, 1.48 \mathrm{mmol}$ ). After $30 \mathrm{~min}$, a solution of the aldehyde, prepared in the previous step, in $\mathrm{MeOH}(1.5 \mathrm{~mL})$ at $0{ }^{\circ} \mathrm{C}$ was added via cannula. The reaction mixture was warmed to room temperature over $1 \mathrm{~h}$, stirred at room temperature for $24 \mathrm{~h}$, and diluted with ether and water. The aqueous phase was extracted with ether $(4 \mathrm{x})$ and the combined organic extracts were washed with brine $(1 \mathrm{x})$, dried over $\mathrm{MgSO}_{4}$, and concentrated. Purification by flash column chromatography on silica gel (5\% to $10 \%$ EtOAc in petroleum ether) gave alkyne 63 (86 mg, $87 \%)$ as a colorless oil: $\mathrm{R}_{f}=0.45(10 \%$ EtOAc in petroleum ether $) ;{ }^{1} \mathrm{H}$ NMR $\left(500 \mathrm{MHz}, \mathrm{CDCl}_{3}\right)$ $\delta 5.87$ (dddd, $J=17.1,13.7,10.1,6.8 \mathrm{~Hz}, 1 \mathrm{H}), 5.44$ (s, 1H), 5.33 (s, 1H), 5.15-5.08 (m, 2H), $4.58(\mathrm{~d}, J=6.1 \mathrm{~Hz}, 1 \mathrm{H}), 4.52(\mathrm{dd}, J=6.2,2.2 \mathrm{~Hz}, 1 \mathrm{H}), 4.17(\mathrm{~d}, J=7.9 \mathrm{~Hz}, 1 \mathrm{H}), 3.89$ (ddd, $J=$ 7.7, 7.7, 3.8 Hz, 1H), 2.50 (d, $J=2.1 \mathrm{~Hz}, 1 \mathrm{H}), 2.47$ (m, 1H), 2.29 (ddddd, $J=14.7,7.3,7.3,1.3$, $1.3 \mathrm{~Hz}, 1 \mathrm{H}), 2.06-1.61(\mathrm{~m}, 16 \mathrm{H}) ;{ }^{13} \mathrm{C} \mathrm{NMR}\left(126 \mathrm{MHz}, \mathrm{CDCl}_{3}\right) \delta 142.9,134.1,120.7,119.1$, $117.4,116.1,81.7,81.2,80.4,79.5,74.4,70.6,37.6,37.1,36.7,36.6,36.3,23.9,23.5,23.4$, 22.9; IR (neat) 3303, 2959, 1642, 1334, 1207, $1107 \mathrm{~cm}^{-1}$; ESIMS m/z $367.4[\mathrm{M}+\mathrm{Na}]^{+}$; optical rotation $[\alpha]_{\mathrm{D}}{ }^{24}+1.6^{\circ}\left(c 1.0, \mathrm{CH}_{2} \mathrm{Cl}_{2}\right)$; Anal. Calcd for $\mathrm{C}_{21} \mathrm{H}_{28} \mathrm{O}_{4}$ : C, 73.23; H, 8.19. Found: $\mathrm{C}$, $73.35 ; \mathrm{H}, 8.28$.
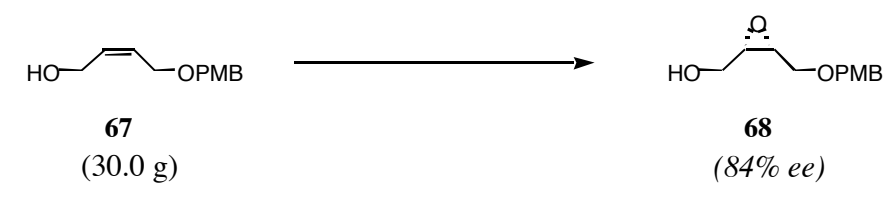

To a suspension of $27 \mathrm{~g}$ of freshly activated $3 \AA$ powdered molecular sieves (heated to $140^{\circ} \mathrm{C}$ at 1 Torr for $14 \mathrm{~h}$ then cooled to rt) in $250 \mathrm{~mL}$ of methylene chloride was added a solution 
of $17.7 \mathrm{~g}(86 \mathrm{mmol})$ of freshly distilled (+)-diethyltartrate in $40 \mathrm{~mL}$ of methylene chloride. The resulting mixture was cooled to $-30^{\circ} \mathrm{C}$ whereupon $20.5 \mathrm{~g}(21.2 \mathrm{~mL}, 72 \mathrm{mmol})$ of distilled titanium tetraisopropoxide and $145 \mathrm{~mL}(72-86 \mathrm{mmol})$ of a 5-6 M stock solution of $t \mathrm{BuOOH}$ in decane (NOTE: the $t \mathrm{BuOOH}$ decane solution was predried over $4 \AA$ molecular sieve pellets for 20 minutes just prior to use) were successively added and the resulting yellow mixture was stirred at $-30^{\circ} \mathrm{C}$ for 30 minutes. During this time, a solution of $30.0 \mathrm{~g}$ (144 mmol) of allylic alcohol 67 in $150 \mathrm{~mL}$ of methylene chloride was predried over $4 \AA$ molecular sieve pellets for 20 min, then the solution was transferred via cannula over 30 min into the previously prepared reaction mixture at $-30^{\circ} \mathrm{C}$. The reaction flask was then placed into a $-20^{\circ} \mathrm{C}$ freezer and allowed to remain at that temperature without stirring for $40 \mathrm{~h}$ whereupon the mixture was filtered to remove the sieves and slowly poured into a well-stirred $0^{\circ} \mathrm{C}$ solution of $236 \mathrm{~g}(86 \mathrm{mmol})$ of iron sulfate heptahydrate and $143 \mathrm{~g}(86 \mathrm{mmol})$ of tartaric acid in $800 \mathrm{~mL}$ of water. After stirring at $0^{\circ} \mathrm{C}$ for $15 \mathrm{~min}$, the layers were separated and the aqueous portion was extracted with diethyl ether $(3 \times 500 \mathrm{~mL})$. The combined organic extracts were cooled to $0^{\circ} \mathrm{C}$ whereupon $140 \mathrm{~mL}$ of $30 \%$ aqueous sodium hydroxide was added. After stirring at $0^{\circ} \mathrm{C}$ for $1 \mathrm{~h}, 500 \mathrm{~mL}$ of water was added and the layers were separated. The aqueous portion was extracted with diethyl ether $(3 \mathrm{x}$ $300 \mathrm{~mL})$ and the combined extracts were washed with brine $(2 \times 200 \mathrm{~mL})$, dried over anhydrous magnesium sulfate, filtered, and concentrated on a rotary evaporator to afford approximately 100 $\mathrm{mL}$ of the crude product as a colorless suspension in residual decane. This material was purified by flash chromatography on silica gel beginning with $80 \% \mathrm{Et}_{2} \mathrm{O}$ in petroleum ether mixture as the eluant to remove the decane and less polar impurities. Finally, elution with 100\% Et2O afforded after concentration in vacuo $23.01 \mathrm{~g}$ (71\%) of pure epoxide $\mathbf{6 8}$ as a yellow oil. The enantiomeric purity of $\mathbf{6 8}$ was determined to be $84 \%$ ee by chiral HPLC analysis : Chiralcel $\mathrm{OD}$ at $23^{\circ} \mathrm{C}, 1.0 \mathrm{~mL} / \mathrm{min}$ flow rate, $15 \%$ isopropanol-heptane, $254 \mathrm{~nm}$, retention times for enantiomers of 68: $13.66 \mathrm{~min}$ (minor), $16.17 \mathrm{~min}$ (major) as compared to a racemic standard of 68. $\mathrm{TLC} \mathrm{Rf}_{\mathrm{f}}=0.22\left(80 \% \mathrm{Et}_{2} \mathrm{O}\right.$ in petroleum ether). IR (film): $3440.2,2934.4,1612.3,1585.9$, 1513.2, 1246.4, 1085.9, 1033.1, 821.4 $\mathrm{cm}^{-1}$. ${ }^{1} \mathrm{H} \mathrm{NMR}\left(300 \mathrm{MHz}, \mathrm{CDCl}_{3}\right) \delta 7.26(\mathrm{~d}, J=8.5 \mathrm{~Hz}$, $2 \mathrm{H}), 6.88(\mathrm{~d}, J=8.6 \mathrm{~Hz}, 2 \mathrm{H}), 4.55$ (d, $J=11.3 \mathrm{~Hz}, 1 \mathrm{H}), 4.46(\mathrm{~d}, J=11.3 \mathrm{~Hz}, 1 \mathrm{H}), 3.81$ (s, 3 H), 3.78-3.67 (m, $3 \mathrm{H}), 3.60(\mathrm{dd}, J=6.0,5.1 \mathrm{~Hz}, 1 \mathrm{H}), 3.30-3.20(\mathrm{~m}, 2 \mathrm{H}), 1.76$ (br s, $1 \mathrm{H})$. $[\alpha]_{\mathrm{D}}^{25}=-17.0\left(\mathrm{c} 2.15, \mathrm{CH}_{2} \mathrm{Cl}_{2}\right)$. 


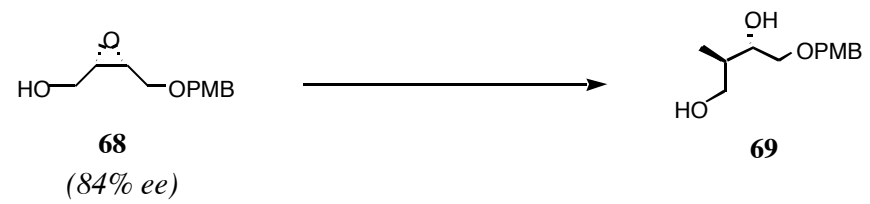

To a slurry of $32.0 \mathrm{~g}(357 \mathrm{mmol})$ of copper cyanide in $350 \mathrm{~mL}$ of diethyl ether at $-40^{\circ} \mathrm{C}$ was added $422.3 \mathrm{~mL}$ ( $663 \mathrm{mmol})$ of a $1.57 \mathrm{M}$ solution of methyllithium-lithium bromide complex in diethyl ether affording a cloudy, off-white colored mixture which was allowed to slowly warm from $-40^{\circ} \mathrm{C}$ to $-20 \mathrm{C}$ over $1.5 \mathrm{~h}$. The reaction mixture was then cooled to $-50^{\circ} \mathrm{C}$ and

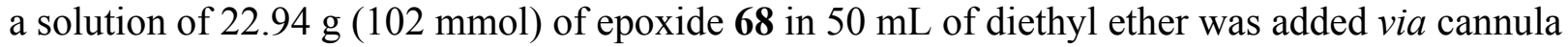
and the resulting mixture was allowed to slowly warm from $-50^{\circ} \mathrm{C}$ to $-20^{\circ} \mathrm{C}$ over $3.5 \mathrm{~h}$. At this time, the reaction was carefully quenched at $-20^{\circ} \mathrm{C}$ by a slow, dropwise addition of $100 \mathrm{~mL}$ of an aqueous solution of saturated ammonium chloride which had been buffered to a $\mathrm{pH} \sim 9$ with conc ammonium hydroxide. After allowing to warm to rt with vigorous stirring for $1 \mathrm{~h}$, the mixture was partitioned between $400 \mathrm{~mL}$ of the ammonium chloride/ammonium hydroxide solution, 200 $\mathrm{mL}$ of water, and $300 \mathrm{~mL}$ of diethyl ether. The aqueous portion was extracted with additional diethyl ether $(2 \times 400 \mathrm{~mL})$ and the combined cloudy organic extracts were filtered through a pad of celite and the resulting clear filtrate was concentrated in vacuo to afford the crude diol mixture as a 2-3:1 regioisomeric mixture of the 1,2-diol and 1,3-diol 69 as determined by ${ }^{1} \mathrm{H}$ NMR analysis. Separation of the desired regioisomeric 1,3-diol from the 1,2-diol was accomplished by dissolving the crude mixture in $400 \mathrm{~mL}$ of $10 \%$ aqueous THF, cooling the resulting solution to $0^{\circ} \mathrm{C}$, and adding $21.8 \mathrm{~g}(102 \mathrm{mmol})$ of sodium periodate. The mixture was warmed to $\mathrm{rt}$ and stirred for $1.5 \mathrm{~h}$ giving a thick, white heterogeneous mixture. After dilution with $1 \mathrm{~L}$ of chloroform, the mixture was decanted away from the white insoluble precipitate which had formed and the resulting solution was washed with brine $(200 \mathrm{~mL})$, dried over anhydrous magnesium sulfate, filtered, and concentrated in vacuo to a yellow oil as the crude product mixture. Flash chromatography on silica gel initially eluting with $80 \%$ ethyl acetate in petroleum ether mixtures removed the aldehyde byproduct followed by elutiing with $100 \%$ ethyl acetate to provide $16.7 \mathrm{~g}(68 \%)$ of pure 69 as a yellow oil. TLC $\mathrm{R}_{\mathrm{f}}=0.42(80 \%$ EtOAc in petroleum ether). IR (film): 3405.6, 2910.9, 1612.8, 1514.0, 1248.6, 1096.6, 1033.8, 819.1 $\mathrm{cm}^{-1} .{ }^{1} \mathrm{H}$ NMR $\left(300 \mathrm{MHz}, \mathrm{CDCl}_{3}\right) \delta 7.22(\mathrm{~d}, J=8.3 \mathrm{~Hz}, 2 \mathrm{H}), 6.86(\mathrm{~d}, J=8.3 \mathrm{~Hz}, 2 \mathrm{H}), 4.50$ 4.41 (m, 2 H), 3.98-3.92 (m, $1 \mathrm{H}), 3.78$ (s, $3 \mathrm{H}), 3.60-3.58$ (m, $2 \mathrm{H}), 3.46(\mathrm{~d}, J=5.9 \mathrm{~Hz}, 2 \mathrm{H})$, 
2.82 ( br s, $2 \mathrm{H}), 1.85-1.78$ ( br m, $1 \mathrm{H}), 0.88(\mathrm{~d}, J=7.3 \mathrm{~Hz}, 3 \mathrm{H}) .{ }^{13} \mathrm{C} \mathrm{NMR}\left(75 \mathrm{MHz}, \mathrm{CDCl}_{3}\right) \delta$ 159.24, 129.78, 129.39, 113.78, 73.02, 72.39, 72.05, 66.06, 55.19, 37.28, 11.00. Anal. Calcd for $\mathrm{C}_{13} \mathrm{H}_{20} \mathrm{O} 4: \mathrm{C}, 64.98 ; \mathrm{H}, 8.39$. Found: $\mathrm{C}, 64.61 ; \mathrm{H}, 8.32$. $[\alpha]_{\mathrm{D}}{ }^{25}=+2.77$ (c 1.70, $\mathrm{CH}_{2} \mathrm{Cl}_{2}$ ).

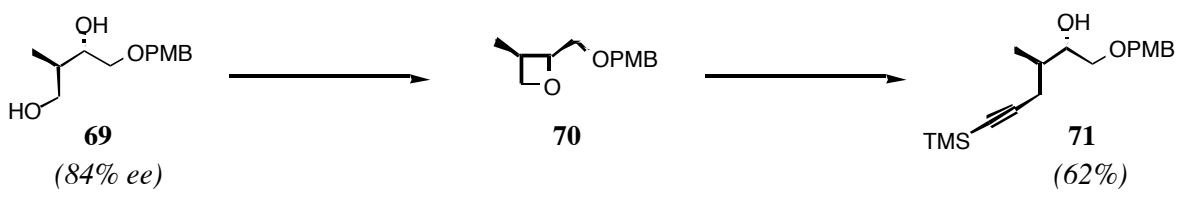

To a solution of $14.4 \mathrm{~g}(60 \mathrm{mmol})$ of diol $69 \mathrm{in} 280 \mathrm{~mL}$ of pyridine at $0^{\circ} \mathrm{C}$ was added $11.4 \mathrm{~g}(60 \mathrm{mmol})$ of freshly purified tosyl chloride in three portions over $15 \mathrm{~min}$ followed by stirring at $0-4^{\circ} \mathrm{C}$ (cold room temp) for $40 \mathrm{~h}$. The cold mixture was then slowly poured into a well-stirred $0^{\circ} \mathrm{C}$ mixture of $10 \%$ aqueous $\mathrm{HCl}(400 \mathrm{~mL})$ and diethyl ether $(400 \mathrm{~mL})$ and the resulting layers were separated. The organic layer was washed with additional ice-cold aqueous $10 \% \mathrm{HCl}(300 \mathrm{~mL})$ and the combined aqueous acidic portions were extracted with diethyl ether $(3 \times 300 \mathrm{~mL})$. The combined organic extracts were successively washed with $300 \mathrm{~mL}$ of $10 \%$ aqueous $\mathrm{HCl}, 300 \mathrm{~mL}$ of $0.2 \mathrm{M}$ aqueous copper sulfate solution, and brine $(2 \times 200 \mathrm{~mL})$, then dried over anhydrous magnesium sulfate, filtered, and concentrated on a rotary evaporator to a total volume of approximately $500 \mathrm{~mL}$. This solution which still contained residual pyridine was washed again with $10 \%$ aqueous $\mathrm{HCl}(3 \times 100 \mathrm{~mL}), 100 \mathrm{~mL}$ of 0.2 aqueous copper sulfate solution, and brine $(2 \times 100 \mathrm{~mL})$, then dried over anhydrous magnesium sulfate, filtered, and concentrated in vacuo to afford a pale yellow oil as the crude tosylate intermediate. Due to the apparent instability of the tosylate, this intermediate was not purified further but was immediately dissolved in $50 \mathrm{~mL}$ of anydrous THF and subjected directly to the next reaction. A relatively pure sample of the tosylate could be obtained by rapid flash chromatography on silica gel ( $50 \% \mathrm{Et}_{2} \mathrm{O}$ in petroleum ether): $\mathrm{TLC} \mathrm{Rf}_{\mathrm{f}}=0.37$ (50\% $\mathrm{Et}_{2} \mathrm{O}$ in petroleum ether). IR (film): $3447.9,2909.5,1612.1,1513.7,1357.6,1248.2,1176.1,965.7,815.7 \mathrm{~cm}^{-1}$. ${ }^{1} \mathrm{H}$ NMR (300 MHz, $\left.\mathrm{CDCl}_{3}\right) \delta 7.76(\mathrm{~d}, J=7.8 \mathrm{~Hz}, 2 \mathrm{H}), 7.32(\mathrm{~d}, J=7.8 \mathrm{~Hz}, 2 \mathrm{H}), 7.22(\mathrm{~d}, J=8.8 \mathrm{~Hz}, 2 \mathrm{H}), 6.88(\mathrm{~d}, J$ $=8.8 \mathrm{~Hz}, 2 \mathrm{H}), 4.43(\operatorname{app~s}, 2 \mathrm{H}), 4.03(\mathrm{dd}, J=9.3,6.8 \mathrm{~Hz}, 1 \mathrm{H}), 3.90(\mathrm{dd}, J=9.8,5.9 \mathrm{~Hz}, 1 \mathrm{H})$, 3.85-3.82 (m, 1 H), 3.80 (s, 3 H), 3.43-3.33 (m, 2 H), 2.43 (s, 3 H), 2.35 (br s, 1 H), 2.04-1.93 (br $\mathrm{m}, 1 \mathrm{H}), 0.87(\mathrm{~d}, J=6.8 \mathrm{~Hz}, 3 \mathrm{H}) .{ }^{13} \mathrm{C} \mathrm{NMR}\left(75 \mathrm{MHz}, \mathrm{CDCl}_{3}\right) \delta 159.25,144.72,132.78,129.79$ (2), 129.34, 127.82, 113.79, 72.95, 72.14, 71.88, 69.49, 55.20, 35.42, 21.57, 10.63. 
The THF solution of the crude tosylate was transferred via cannula into a suspension of $4.80 \mathrm{~g}$ (120 mmol) of $60 \%$ dispersion of sodium hydride in mineral oil in $100 \mathrm{~mL}$ of THF at $\mathrm{rt}$ and the resulting heterogeneous mixture was stirred at $\mathrm{rt}$ for $4 \mathrm{~h}$. At this time, the reaction mixture was carefully quenched by a slow, dropwise addition of $20 \mathrm{~mL}$ of methanol followed by the addition of $100 \mathrm{~mL}$ of water and $100 \mathrm{~mL}$ of diethyl ether. The resulting layers were separated and the aqueous portion was extracted with diethyl ether $(3 \times 75 \mathrm{~mL})$. The combined extracts were washed with brine $(2 \times 25 \mathrm{~mL})$, dried over anhydrous magnesium sulfate, filtered, and concentrated in vacuo to afford a $15.2 \mathrm{~g}$ of a yellow oil as the crude oxetane. Flash chromatography on silica gel (50\% diethyl ether in petroleum ether) afforded $10.9 \mathrm{~g}(82 \%)$ of pure 70 as a pale yellow oil. TLC $\mathrm{Rf}_{\mathrm{f}}=0.57\left(50 \% \mathrm{Et}_{2} \mathrm{O}\right.$ in petroleum ether). IR (film): 2872.2, $1612.5,1513.3,1457.2,1247.6,1094.3,1033.8,969.6,818.8 \mathrm{~cm}^{-1} .{ }^{1} \mathrm{H}$ NMR $\left(300 \mathrm{MHz}, \mathrm{CDCl}_{3}\right)$

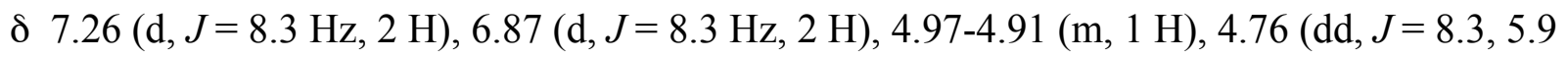
Hz, $1 \mathrm{H}$ ), 4.50 (app q, $J=7.8 \mathrm{~Hz}, 2 \mathrm{H}), 4.18$ (app t, $J=6.3 \mathrm{~Hz}, 1 \mathrm{H}), 3.79$ (s, $3 \mathrm{H}$ ), 3.69 (d, $J=$ $5.9 \mathrm{~Hz}, 2 \mathrm{H}$ ), 3.15 (app sextet, $J=6.8 \mathrm{~Hz}, 1 \mathrm{H}), 1.16$ (d, $J=7.3 \mathrm{~Hz}, 3 \mathrm{H}$ ).

To a solution of $20.8 \mathrm{~mL}(14.4 \mathrm{~g}, 147 \mathrm{mmol})$ of trimethylsilylacetylene in $230 \mathrm{~mL}$ of THF at $-78^{\circ} \mathrm{C}$ was added $92 \mathrm{~mL}(147 \mathrm{mmol})$ of a $1.6 \mathrm{M}$ solution of $n$-butyllithium in hexanes and the resulting clear, colorless solution was stirred at $-78^{\circ} \mathrm{C}$ for $30 \mathrm{~min}$ then at $0^{\circ} \mathrm{C}$ for 45 minutes. The mixture was cooled to $-78^{\circ} \mathrm{C}$ and $18.1 \mathrm{~mL}(20.9 \mathrm{~g}, 147 \mathrm{mmol})$ of freshly distilled boron trifluoride etherate was added followed by stirring for $10 \mathrm{~min}$ whereupon a solution of $10.9 \mathrm{~g} \mathrm{(} 49 \mathrm{mmol})$ of $\mathbf{7 0}$ in $30 \mathrm{~mL}$ of THF was added via cannula. After stirring at $-78^{\circ} \mathrm{C}$ for 45 min, $100 \mathrm{~mL}$ of saturated aqueous ammonium chloride was added and the reaction mixture was allowed to warm to rt whereupon $100 \mathrm{~mL}$ of water and $100 \mathrm{~mL}$ of diethyl ether were added. The resulting layers were separated and the organic portion was washed with $5 \%$ aqueous $\mathrm{HCl}(2 \mathrm{x}$ $100 \mathrm{~mL})$. The aqueous portions were combined and extracted with diethyl ether $(2 \times 150 \mathrm{~mL})$ and the combined organic extracts were washed with saturated aqueous sodium bicarbonate (100 $\mathrm{mL})$, brine $(100 \mathrm{~mL})$, then dried over anhydrous magnesium sulfate, filtered, and concentrated in vacuo to afford $15.5 \mathrm{~g}$ of a yellow oil as the crude product. Flash chromatography on silica gel ( $40 \%$ diethyl ether in petroleum ether) then afforded $10.57 \mathrm{~g} \mathrm{(62 \% )} \mathrm{of} \mathrm{pure} 71$ as a pale yellow oil. $\mathrm{TLC} \mathrm{R}_{\mathrm{f}}=0.43$ (50\% $\mathrm{Et}_{2} \mathrm{O}$ in petroleum ether). IR (film): 3463.3, 2959.4, 2902.6, 2173.1, 1612.9, 1514.0, 1249.4, $843.4 \mathrm{~cm}^{-1}$. ${ }^{1} \mathrm{H}$ NMR $\left(300 \mathrm{MHz}, \mathrm{CDCl}_{3}\right) \delta 7.24$ (d, $\left.J=8.3 \mathrm{~Hz}, 2 \mathrm{H}\right)$, 
$6.86(\mathrm{~d}, J=8.8 \mathrm{~Hz}, 2 \mathrm{H}), 4.46(\mathrm{~s}, 2 \mathrm{H}), 3.82(\mathrm{~m}, 1 \mathrm{H}), 3.78(\mathrm{~s}, 3 \mathrm{H}), 3.49$ (dd, $J=9.8,3.4 \mathrm{~Hz}, 1$ H), 3.41 (apparent t, $J=9.8 \mathrm{~Hz}, 1 \mathrm{H}), 2.41$ (br m, $1 \mathrm{H}), 2.31$ (dd, $J=17.1,6.4 \mathrm{~Hz}, 1 \mathrm{H}), 2.17$ (dd, $J=17.1,6.8 \mathrm{~Hz}, 1 \mathrm{H}), 1.80(\mathrm{~m}, 1 \mathrm{H}), 1.00(\mathrm{~d}, J=6.8 \mathrm{~Hz}, 3 \mathrm{H}), 0.13(\mathrm{~s}, 9 \mathrm{H}) .{ }^{13} \mathrm{C} \mathrm{NMR}(75$ $\left.\mathrm{MHz}, \mathrm{CDCl}_{3}\right) \delta 159.21,129.94,129.31,113.76,105.70,85.92,72.92,72.42,72.28,55.17$, 35.06, 23.98, 14.22, 0.05. Anal. Calcd for $\mathrm{C}_{18} \mathrm{H}_{28} \mathrm{O}_{3} \mathrm{Si}: \mathrm{C}, 67.46 ; \mathrm{H}, 8.81$. Found: C, 67.59; $\mathrm{H}$, 8.83. $[\alpha]_{\mathrm{D}}^{26}=+11.5\left(\mathrm{c} 3.8, \mathrm{CH}_{2} \mathrm{Cl}_{2}\right)$.

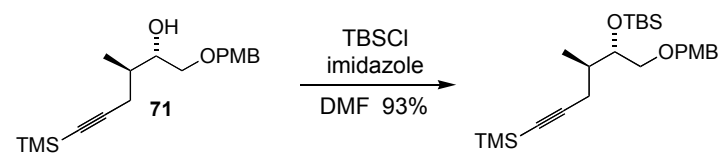

Alcohol 71 (75 mg, $0.234 \mathrm{mmol})$ was dissolved in $2 \mathrm{~mL}$ of DMF. Imidazole $(21 \mathrm{mg}$, $0.304 \mathrm{mmol}$ ) was then added followed by TBDMSCl (46 mg, $0.304 \mathrm{mmol})$. After $22 \mathrm{~h}$ the reaction was taken up in diethyl ether and washed with water $(1 \mathrm{x})$ and brine $(2 \mathrm{x})$. The organic layer was then dried $\left(\mathrm{MgSO}_{4}\right)$ and concentrated. Purification by silica gel chromatography (2-6\% Et2O/petroleum ether) provided $94 \mathrm{mg}(93 \%)$ of the silyl ether as an oil: $R_{f}=0.37(5 \%$ $\mathrm{Et}_{2} \mathrm{O} / 95 \%$ petroleum ether); IR (film from $\mathrm{CH}_{2} \mathrm{Cl}_{2}$ ) 2959, 2859, 2170, $1609 \mathrm{~cm}^{-1} ;{ }^{1} \mathrm{H}$ NMR (300 $\left.\mathrm{MHz} \mathrm{CDCl}_{3}\right) \delta 7.35(\mathrm{~d}, J=8.5 \mathrm{~Hz}, 2 \mathrm{H}), 6.97(\mathrm{~d}, J=8.5 \mathrm{~Hz}, 2 \mathrm{H}), 4.54(\mathrm{q}, J=11.5 \mathrm{~Hz}, 2 \mathrm{H})$, 4.05-4.10 (m, 1H), $3.91(\mathrm{~s}, 3 \mathrm{H}), 3.47(\mathrm{~d}, J=6.1 \mathrm{~Hz}, 2 \mathrm{H}), 2.30(\mathrm{qd}, J=16.8,7.8,2 \mathrm{H}), 1.97-2.05$ $(\mathrm{m}, 1 \mathrm{H}), 0.98(\mathrm{~d}, J=6.8 \mathrm{~Hz}, 3 \mathrm{H}), 0.96(\mathrm{~s}, 9 \mathrm{H}), 0.24(\mathrm{~s}, 9 \mathrm{H}), 0.17(\mathrm{~s}, 3 \mathrm{H}), 0.14(\mathrm{~s}, 3 \mathrm{H}) ;{ }^{13} \mathrm{C} \mathrm{NMR}$ $\left(75 \mathrm{MHz}, \mathrm{CDCl}_{3}\right) \delta 159.0,130.4,129.2,113.6,106.7,85.4,72.7,72.6,72.0,55.2,35.7,25.9$, $24.5,18.1,13.0,0.1,-4.2,-5.0 .[\alpha]_{\mathrm{D}}{ }^{23}=-4.8\left(\mathrm{c} 1.2, \mathrm{CH}_{2} \mathrm{Cl}_{2}\right)$. Anal calcd for $\mathrm{C}_{24} \mathrm{H}_{42} \mathrm{O}_{3} \mathrm{Si}_{2}: \mathrm{C}$, 66.30; H, 9.74. Found: C, 66.49; H, 9.62.

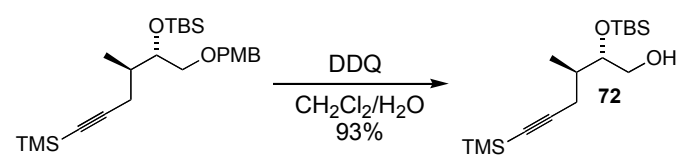

The protected alcohol (155 $\mathrm{mg}, 0.357 \mathrm{mmol})$ was dissolved in $3 \mathrm{~mL}$ of dichloromethane, $1 \mathrm{~mL}$ of water was then added followed by DDQ (97 $\mathrm{mg}, 0.428 \mathrm{mmol})$. The reaction was then stirred for $1 \mathrm{~h}$, after which it was poured into diethyl ether and washed with sat. aq. $\mathrm{NaHCO}_{3}$ $(3 \mathrm{x})$. The organic layer was then dried $\left(\mathrm{MgSO}_{4}\right)$ and concentrated. Purification by silica gel chromatography (20-40\% Et $2 \mathrm{O} /$ petroleum ether) provided $72(104 \mathrm{mg}, 93 \%)$ as a clear oil: $R_{f}=$ 0.58 (30\% $\mathrm{Et}_{2} \mathrm{O} / 70 \%$ petroleum ether); IR (neat) 3402, 2949, $2170 \mathrm{~cm}^{-1} ;{ }^{1} \mathrm{H}$ NMR (500 MHz, 
$\left.\mathrm{CDCl}_{3}\right)$ \& $3.79(\mathrm{q}, J=4.7 \mathrm{~Hz}, 1 \mathrm{H}), 3.54-3.60(\mathrm{~m}, 2 \mathrm{H}), 2.29(\mathrm{dd}, J=16.8,6.0,1 \mathrm{H}), 2.16(\mathrm{dd}, J=$ 16.8, 6.8 Hz, 1H), 1.86-1.91 (m, 1H), 1.70 (s, 1H), 0.97 (d, J=7.1 Hz, 3H), 0.90 (s, 9H), 0.14 (s, 9H), 0.10 (s, 3H), 0.09 (s, 3H); ${ }^{13} \mathrm{C}$ NMR (125 MHz, $\left.\mathrm{CDCl}_{3}\right) \delta$ 106.0, 85.8, 74.5, 64.5, 35.6, $25.8,23.8,18.1,14.6,0.1,-4.3,-4.7 .[\alpha]_{\mathrm{D}}^{23}=-5.7\left(c 1.0, \mathrm{CH}_{2} \mathrm{Cl}_{2}\right)$.

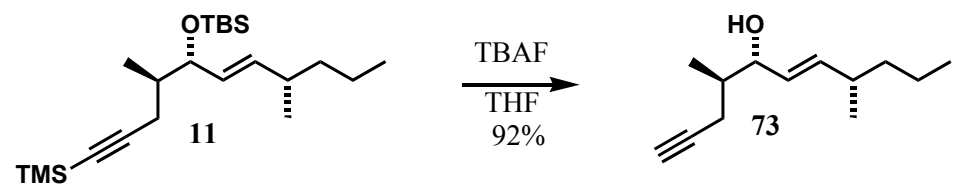

Alkene 11 (650 mg, $1.71 \mathrm{mmol})$ was dissolved in $8 \mathrm{~mL}$ of THF. Tetrabutylammonium fluoride (1M in THF, $3.76 \mathrm{~mL}, 3.76 \mathrm{mmol})$ was then added. After approximately $24 \mathrm{~h}$ the reaction was poured into sat. aq. $\mathrm{NaHCO}_{3}$ and extracted with ethyl ether (4x). The combined organic extracts were then dried $\left(\mathrm{MgSO}_{4}\right)$ and concentrated. Purification by silica gel chromatography $\left(20-30 \% \mathrm{Et}_{2} \mathrm{O} /\right.$ petroleum ether) provided $73(305 \mathrm{mg}, 92 \%)$ as a clear oil: $R_{f}=$ $0.43\left(20 \% \mathrm{Et}_{2} \mathrm{O} / 80 \%\right.$ petroleum ether); IR (film from $\mathrm{CH}_{2} \mathrm{Cl}_{2}$ ) 3402, 3312, 2958, $2116 \mathrm{~cm}^{-1} ;{ }^{1} \mathrm{H}$ NMR $\left(300 \mathrm{MHz}, \mathrm{CDCl}_{3}\right) \delta 5.55(\mathrm{dd}, J=15.6,7.6 \mathrm{~Hz}, 1 \mathrm{H}), 5.40(\mathrm{dd}, J=15.6,7.0 \mathrm{~Hz}, 1 \mathrm{H}), 4.08$ (t, $J=5.9 \mathrm{~Hz}, 1 \mathrm{H}), 2.33(\mathrm{ddd}, J=16.6,5.9,2.7 \mathrm{~Hz}, 1 \mathrm{H}), 2.12-2.17$ (m, 1H), 2.08 (ddd, $J=16.6$, 7.3, $2.4 \mathrm{~Hz}, 1 \mathrm{H}), 1.98(\mathrm{t}, J=2.4 \mathrm{~Hz}, 1 \mathrm{H}), 1.74-1.86(\mathrm{~m}, 1 \mathrm{H}), 1.22-1.32(\mathrm{~m}, 4 \mathrm{H}), 1.02(\mathrm{~d}, J=6.8$ $\mathrm{Hz}, 3 \mathrm{H}), 0.97(\mathrm{~d}, J=6.6 \mathrm{~Hz}, 3 \mathrm{H}), 0.88(\mathrm{t}, J=6.9 \mathrm{~Hz}, 3 \mathrm{H}) ;{ }^{13} \mathrm{C} \mathrm{NMR}\left(75 \mathrm{MHz}, \mathrm{CDCl}_{3}\right) \delta 139.0$, $128.6,83.3,75.5,69.4,39.1,38.2,36.2,25.6,22.1,20.5,14.5,14.1 .[\alpha]_{\mathrm{D}}^{23}=+2.7(\mathrm{c} 0.7$, $\mathrm{CH}_{2} \mathrm{Cl}_{2}$ ).

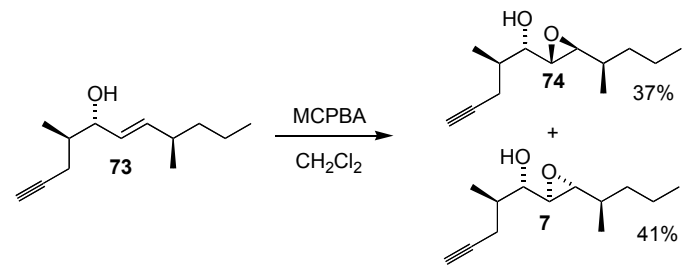

Alkene 73 (125 mg, $0.643 \mathrm{mmol}$ ) was dissolved in $5 \mathrm{~mL}$ of methylene chloride and cooled to $0{ }^{\circ} \mathrm{C}$. $\mathrm{mCPBA}(68 \%, 171 \mathrm{mg}, 0.675 \mathrm{mmol})$ was then added in small portions over 5 min. After approximately $2 \mathrm{~h}$ the reaction was poured into $40 \mathrm{~mL}$ of sat. aq. $\mathrm{NaHCO}_{3}$ and extracted with ethyl ether $(3 \mathrm{x})$. The combined organic extracts were then dried $\left(\mathrm{MgSO}_{4}\right)$ and concentrated. Purification by silica gel chromatography $\left(25 \% \mathrm{Et}_{2} \mathrm{O} /\right.$ petroleum ether) provided 50 $\mathrm{mg}(37 \%)$ of the trans epoxide (74) and $56 \mathrm{mg}(41 \%)$ of the cis epoxide (7) as clear oils. Data for 
74: $R_{f}=0.41\left(30 \% \mathrm{Et}_{2} \mathrm{O} / 70 \%\right.$ petroleum ether); IR (film from $\left.\mathrm{CH}_{2} \mathrm{Cl}_{2}\right) 3465,3302,2959,2116$ $\mathrm{cm}^{-1}$; ${ }^{1} \mathrm{H}$ NMR (300 MHz, $\mathrm{CDCl}_{3}$ ) $\delta$ 3.85-3.91 (m, 1H), 2.80-2.87 (m, 2H), 2.38 (ddd, $J=16.8$, 6.8, $2.7 \mathrm{~Hz}, 1 \mathrm{H}), 2.24$ (ddd, $J=16.8,7.1,2.7 \mathrm{~Hz}, 1 \mathrm{H}), 2.00$ (t, $J=2.7 \mathrm{~Hz}, 1 \mathrm{H}), 1.87-1.98$ (m, 2H), $1.20-1.49(\mathrm{~m}, 5 \mathrm{H}), 1.06$ (d, $J=6.8 \mathrm{~Hz}, 3 \mathrm{H}), 1.00(\mathrm{~d}, J=6.3 \mathrm{~Hz}, 3 \mathrm{H}), 0.91$ (t, $J=6.8 \mathrm{~Hz}$, $3 \mathrm{H}) ;{ }^{13} \mathrm{C} \mathrm{NMR}\left(75 \mathrm{MHz}, \mathrm{CDCl}_{3}\right) \delta 82.7,70.8,69.7,60.1,58.9,35.6,35.5,34.9,22.7,20.1,16.6$, 14.2, 14.0. HRMS calcd for $\mathrm{C}_{10} \mathrm{H}_{15} \mathrm{O}_{2}\left(\mathrm{M}-\mathrm{C}_{3} \mathrm{H}_{7}\right): 167.1072$. Found: 167.1074. $[\alpha]_{\mathrm{D}}{ }^{23}=+1.0(c$ 1.0, $\left.\mathrm{CH}_{2} \mathrm{Cl}_{2}\right)$. Data for 7: $R_{f}=0.32\left(30 \% \mathrm{Et}_{2} \mathrm{O} / 70 \%\right.$ petroleum ether); IR (film from $\mathrm{CH}_{2} \mathrm{Cl}_{2}$ ) 3457, 3311, 2958, $2116 \mathrm{~cm}^{-1}$; ${ }^{1} \mathrm{H}$ NMR (300 MHz, $\left.\mathrm{CDCl}_{3}\right) \delta$ 8.54-3.61 (m, 1H), 2.82 (dd, $J=$ 4.6, $2.2 \mathrm{~Hz}, 1 \mathrm{H}), 2.73(\mathrm{dd}, J=7.1,2.2 \mathrm{~Hz}, 1 \mathrm{H}), 2.36$ (ddd, $J=16.8,6.8,2.7 \mathrm{~Hz}, 1 \mathrm{H}), 2.22$ (ddd, $J=16.8,6.8,2.7 \mathrm{~Hz}, 1 \mathrm{H}), 2.11(\mathrm{~d}, J=5.1 \mathrm{~Hz}, 1 \mathrm{H}), 1.99(\mathrm{t}, J=2.7 \mathrm{~Hz}, 1 \mathrm{H}), 1.86-1.94(\mathrm{~m}, 2 \mathrm{H})$, $1.20-1.53(\mathrm{~m}, 4 \mathrm{H}), 1.07(\mathrm{~d}, J=6.8 \mathrm{~Hz}, 3 \mathrm{H}), 0.88-0.97(\mathrm{~m}, 6 \mathrm{H}) ;{ }^{13} \mathrm{C} \mathrm{NMR}\left(75 \mathrm{MHz}, \mathrm{CDCl}_{3}\right) \delta$ 82.6, 72.7, 69.7, 61.0, 58.8, 37.0, 36.7, 35.0, 22.4, 20.0, 15.7, 14.2, 14.1. HRMS calcd for $\mathrm{C}_{10} \mathrm{H}_{15} \mathrm{O}_{2}\left(\mathrm{M}-\mathrm{C}_{3} \mathrm{H}_{7}\right): 167.1072$. Found: $167.1076[\alpha]_{\mathrm{D}}{ }^{23}=+34.7\left(c 1.1, \mathrm{CH}_{2} \mathrm{Cl}_{2}\right)$.
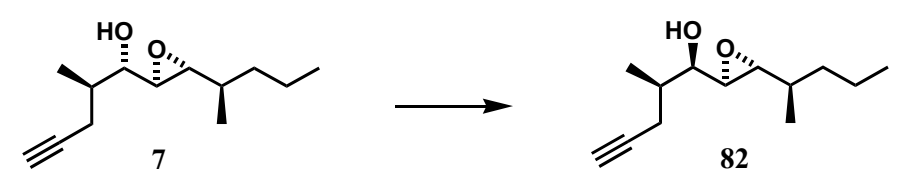

To a solution of alcohol $7(127 \mathrm{mg}, 0.604 \mathrm{mmol})$ in $\mathrm{PhMe}(5 \mathrm{~mL})$ at room temperature was added triphenylphosphine (193 mg, $0.736 \mathrm{mmol}), p$-nitrobenzoic acid (128 mg, 0.766 $\mathrm{mmol}$ ), and DIAD (145 $\mu \mathrm{L}, 149 \mathrm{mg}, 0.736 \mathrm{mmol})$. The reaction mixture was stirred at room temperature for $4 \mathrm{~h}$, concentrated, and filtered through silica gel (2.5\% to 5\% EtOAc in petroleum ether) to give the ester which was used in the next step without purification. PH8-15: To a solution of the ester, prepared in the previous step, in $\mathrm{MeOH}(6 \mathrm{~mL})$ at $0^{\circ} \mathrm{C}$ was added $\mathrm{NaOMe}(62 \mathrm{mg}, 1.1 \mathrm{mmol})$. The reaction mixture was stirred at $0^{\circ} \mathrm{C}$ for $1 \mathrm{~h}$ and diluted with ether, $\mathrm{pH} 7$ buffer, and water. The aqueous phase was extracted with ether $(5 \mathrm{x})$ and the combined organic extracts were washed with brine $(1 \mathrm{x})$, dried over $\mathrm{MgSO}_{4}$, and concentrated. Purification by flash column chromatography on silica gel $\left(\mathrm{CH}_{2} \mathrm{Cl}_{2}\right)$ gave alcohol $82(31 \mathrm{mg}$, 24\%) as a colorless oil: $\mathrm{R}_{f}=0.27\left(\mathrm{CH}_{2} \mathrm{Cl}_{2}\right) ;{ }^{1} \mathrm{H}$ NMR $\left(400 \mathrm{MHz}, \mathrm{CDCl}_{3}\right) \delta 3.69(\mathrm{dt}, J=7.3,3.1$ $\mathrm{Hz}, 1 \mathrm{H}), 2.89$ (dd, $J=3.4,2.4 \mathrm{~Hz}, 1 \mathrm{H}), 2.80$ (dd, $J=7.3,2.4 \mathrm{~Hz}, 1 \mathrm{H}), 2.43$ (ddd, $J=16.8,4.4$, $2.6 \mathrm{~Hz}, 1 \mathrm{H}), 2.32$ (ddd, $J=16.8,7.5,2.7 \mathrm{~Hz}, 1 \mathrm{H}), 1.99$ (t, $J=2.3 \mathrm{~Hz}, 1 \mathrm{H}), 1.84(\mathrm{~m}, 1 \mathrm{H}), 1.55-$ $1.26(\mathrm{~m}, 6 \mathrm{H}), 1.13$ (d, $J=6.9 \mathrm{~Hz}, 3 \mathrm{H}), 0.93$ (t, $J=7.3 \mathrm{~Hz}, 3 \mathrm{H}), 0.90(\mathrm{~d}, J=7.2 \mathrm{~Hz}, 3 \mathrm{H}) ;{ }^{13} \mathrm{C}$ 
NMR (101 MHz, $\left.\mathrm{CDCl}_{3}\right) \delta 82.5,70.9,69.8,59.3,57.9,36.7,36.4,35.1,22.0,20.0,15.9,15.1$, 14.2; IR (neat) 3457 (br), 3303, 2959, 2352, $1460 \mathrm{~cm}^{-1}$; CIMS calcd for $\mathrm{C}_{13} \mathrm{H}_{23} \mathrm{O}_{2}\left(\mathrm{M}^{+}+\mathrm{H}\right)$ 211.2, found 211.1; optical rotation $[\alpha]_{\mathrm{D}}{ }^{27}+7.8^{\circ}\left(c 0.50, \mathrm{CH}_{2} \mathrm{Cl}_{2}\right)$.

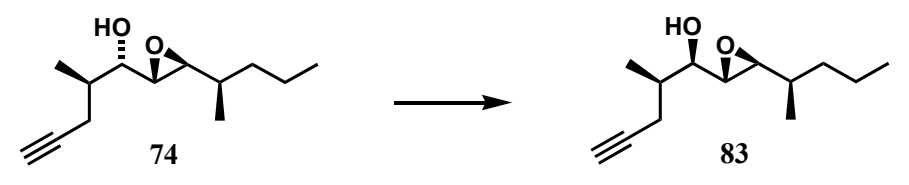

To a solution of alcohol $74(323 \mathrm{mg}, 1.54 \mathrm{mmol})$ in PhMe (12 mL) at room temperature was added triphenylphosphine (486 mg, $1.85 \mathrm{mmol}$ ), p-nitrobenzoic acid (308 mg, $1.84 \mathrm{mmol}$ ), and DIAD (365 $\mu \mathrm{L}, 375 \mathrm{mg}, 1.85 \mathrm{mmol})$. The reaction mixture was stirred at room temperature for $3 \mathrm{~h}$, concentrated, and filtered through silica gel (2.5\% to 5\% to $10 \%$ EtOAc in petroleum ether) to give the ester which was used in the next step without purification. PH9-30: To a solution of the ester, prepared in the previous step, in $\mathrm{MeOH}(28 \mathrm{~mL})$ at $0^{\circ} \mathrm{C}$ was added $\mathrm{NaOMe}$ (300 mg, $5.55 \mathrm{mmol}$ ). The reaction mixture was stirred at $0^{\circ} \mathrm{C}$ for $2.5 \mathrm{~h}$ and diluted with ether, $\mathrm{pH} 7$ buffer, and water. The aqueous phase was extracted with ether $(6 \mathrm{x})$ and the combined organic extracts were washed with brine (1 $\mathrm{x})$, dried over $\mathrm{MgSO}_{4}$, and concentrated. Purification by flash column chromatography on silica gel $\left(\mathrm{CH}_{2} \mathrm{Cl}_{2}\right.$ to $50 \%$ EtOAc in $\left.\mathrm{CH}_{2} \mathrm{Cl}_{2}\right)$ gave alcohol 83 (273 mg, 85\%) as a colorless oil: $\mathrm{R}_{f}=0.30$ (20\% EtOAc in petroleum ether); ${ }^{1} \mathrm{H}$ NMR (400 $\left.\mathrm{MHz}, \mathrm{CDCl}_{3}\right) \delta 3.36(\mathrm{dd}, J=12.7,5.5 \mathrm{~Hz}, 1 \mathrm{H}), 2.88(\mathrm{dd}, J=4.9,2.3 \mathrm{~Hz}, 1 \mathrm{H}), 2.75(\mathrm{dd}, J=6.9$, $2.3 \mathrm{~Hz}, 1 \mathrm{H}), 2.41$ (ddd, $J=16.8,4.9,2.7 \mathrm{~Hz}, 1 \mathrm{H}), 2.34$ (ddd, $J=16.8,7.0,2.6 \mathrm{~Hz}, 1 \mathrm{H}), 2.12$ (d br, $J=5.8 \mathrm{~Hz}, 1 \mathrm{H}), 1.98(\mathrm{t}, J=2.6 \mathrm{~Hz}, 1 \mathrm{H}), 1.90(\mathrm{~m}, 1 \mathrm{H}), 1.43-1.20(\mathrm{~m}, 5 \mathrm{H}), 1.10(\mathrm{~d}, J=6.9$ $\mathrm{Hz}, 3 \mathrm{H}), 1.00$ (d, $J=6.6 \mathrm{~Hz}, 3 \mathrm{H}), 0.90(\mathrm{t}, J=6.9 \mathrm{~Hz}, 3 \mathrm{H}) ;{ }^{13} \mathrm{C} \mathrm{NMR}\left(101 \mathrm{MHz}, \mathrm{CDCl}_{3}\right) \delta 82.4$, 73.6, 69.8, 61.8, 59.6, 36.5, 35.4, 35.0, 21.8, 20.2, 16.7, 15.5, 14.2; IR (neat) 3457 (br), 3312, 2959, 2361, $1460 \mathrm{~cm}^{-1}$; CIMS calcd for $\mathrm{C}_{13} \mathrm{H}_{23} \mathrm{O}_{2}\left(\mathrm{M}^{+}+\mathrm{H}\right)$ 211.2, found 211.2; optical rotation $[\alpha]_{D}^{26}-23^{\circ}\left(c 2.0, \mathrm{CH}_{2} \mathrm{Cl}_{2}\right)$; Anal. Calcd for $\mathrm{C}_{13} \mathrm{H}_{22} \mathrm{O}_{2}: \mathrm{C}, 74.24 ; \mathrm{H}, 10.54$. Found: $\mathrm{C}, 74.38 ; \mathrm{H}$, 10.34 .

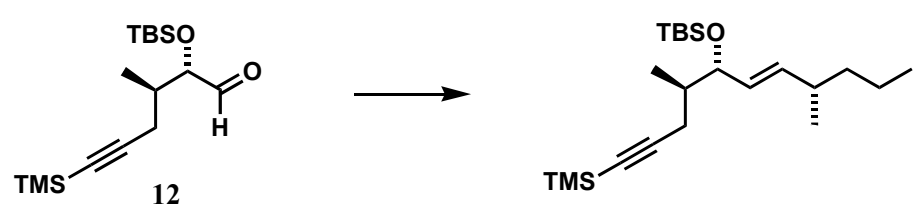


To KN(TMS) $2(6.4 \mathrm{~mL}, 0.47 \mathrm{M}$ in DME, $3.0 \mathrm{mmol})$ at $-78^{\circ} \mathrm{C}$ was added a solution of ent-13 $(823 \mathrm{mg}, 2.80 \mathrm{mmol})$ in $\mathrm{DME}(6 \mathrm{~mL})$ at $-78^{\circ} \mathrm{C}$. The solution was stirred at $-78^{\circ} \mathrm{C}$ for $1 \mathrm{~h}$ and a solution of aldehyde $12(677 \mathrm{mg}, 2.17 \mathrm{mmol})$ in DME $(6 \mathrm{~mL})$ at $-78^{\circ} \mathrm{C}$ was added via cannula. The reaction mixture was warmed from $-78^{\circ} \mathrm{C}$ to room temperature over $3 \mathrm{~h}$, stirred at room temperature for $10 \mathrm{~h}$, partially concentrated, and diluted with ether and water. The aqueous phase was extracted with ether $(5 \mathrm{x})$ and the combined organic extracts were washed with brine ( $1 \mathrm{x})$, dried over $\mathrm{MgSO}_{4}$, and concentrated. Purification by flash column chromatography on silica gel (1\% to $2 \%$ EtOAc in petroleum ether) gave the alkene $(614 \mathrm{mg}, 74 \%)$ as a colorless oil: $\mathrm{R}_{f}=0.71$ (5\% EtOAc in petroleum ether); ${ }^{1} \mathrm{H}$ NMR $\left(400 \mathrm{MHz}, \mathrm{CDCl}_{3}\right) \delta 5.39(\mathrm{dd}, J=15.4,7.3$ $\mathrm{Hz}, 1 \mathrm{H}), 5.30(\mathrm{dd}, J=15.4,6.9 \mathrm{~Hz}, 1 \mathrm{H}), 4.04$ (dd, $J=6.9,4.9 \mathrm{~Hz}, 1 \mathrm{H}), 2.30$ (dd, $J=16.8,5.8$ $\mathrm{Hz}, 1 \mathrm{H}), 2.10(\mathrm{~m}, 1 \mathrm{H}), 2.05(\mathrm{dd}, J=16.9,7.8 \mathrm{~Hz}, 1 \mathrm{H}), 1.68(\mathrm{~m}, 1 \mathrm{H}), 1.32-1.21(\mathrm{~m}, 4 \mathrm{H}), 0.963$ $(\mathrm{d}, J=6.7 \mathrm{~Hz}, 3 \mathrm{H}), 0.957(\mathrm{~d}, J=6.7 \mathrm{~Hz}, 3 \mathrm{H}), 0.89-0.86(\mathrm{~m}, 3 \mathrm{H}), 0.88(\mathrm{~s}, 9 \mathrm{H}), 0.15(\mathrm{~s}, 9 \mathrm{H}), 0.04$ (s, 3H), $0.00(\mathrm{~s}, 3 \mathrm{H}) ;{ }^{13} \mathrm{C}$ NMR $\left(101 \mathrm{MHz}, \mathrm{CDCl}_{3}\right) \delta 137.7,129.8,106.9,85.3,76.0,39.6,39.2$, $36.3,25.9,23.7,20.6,20.5,18.2,14.4,14.1,0.17,-4.0,-4.9$; IR (neat) 2953, 2176, 1247, 1032, $842 \mathrm{~cm}^{-1}$; EIMS m/z 147 (57), 81 (50), 73 (97), 71 (69), 69 (100); HREIMS calcd for $\mathrm{C}_{18} \mathrm{H}_{35} \mathrm{OSi}_{2}$ $\left(\mathrm{M}^{+}\right.$- tert-butyl) 323.2226, found 323.2191; optical rotation $[\alpha]_{\mathrm{D}}{ }^{26}+24^{\mathrm{o}}\left(\mathrm{c} 1.0, \mathrm{CH}_{2} \mathrm{Cl}_{2}\right)$.

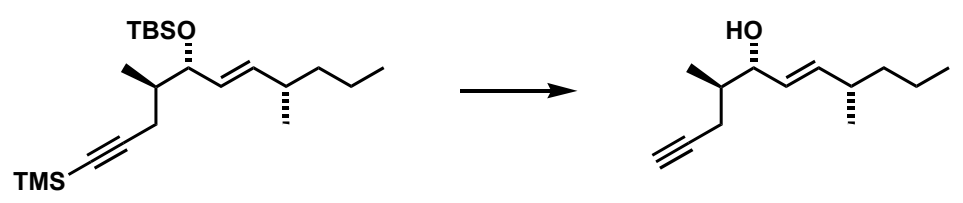

To a solution of the silyl ether $(608 \mathrm{mg}, 1.60 \mathrm{mmol})$ in THF $(3.5 \mathrm{~mL})$ at room temperature was added TBAF $(3.5 \mathrm{~mL}, 1 \mathrm{M}$ in THF, $3.5 \mathrm{mmol})$. The reaction mixture was stirred at room temperature for $24 \mathrm{~h}$ and concentrated. Purification by flash column chromatography on silica gel (5\% to $10 \%$ to $20 \%$ EtOAc in petroleum ether) gave the alcohol $(272 \mathrm{mg}, 88 \%)$ as a colorless oil: $\mathrm{R}_{f}=0.41\left(20 \%\right.$ EtOAc in petroleum ether); ${ }^{1} \mathrm{H}$ NMR $\left(400 \mathrm{MHz}, \mathrm{CDCl}_{3}\right) \delta 5.53$ (ddd, $J=15.4,7.8,0.9 \mathrm{~Hz}, 1 \mathrm{H}), 5.40$ (ddd, $J=15.4,7.0,0.9 \mathrm{~Hz}, 1 \mathrm{H}), 4.06(\mathrm{~m}, 1 \mathrm{H}), 2.32$ (ddd, $J$ $=16.8,5.8,2.6 \mathrm{~Hz}, 1 \mathrm{H}), 2.13(\mathrm{~m}, 1 \mathrm{H}), 2.08(\mathrm{ddd}, J=16.8,7.6,2.8 \mathrm{~Hz}, 1 \mathrm{H}), 1.97(\mathrm{t}, J=2.6 \mathrm{~Hz}$, $1 \mathrm{H}), 1.80(\mathrm{~m}, 1 \mathrm{H}), 1.60(\mathrm{~d} \mathrm{br}, J=3.8 \mathrm{~Hz}, 1 \mathrm{H}), 1.30-1.23(\mathrm{~m}, 4 \mathrm{H}), 1.02(\mathrm{~d}, J=6.9 \mathrm{~Hz}, 3 \mathrm{H}), 0.97$ $(\mathrm{d}, J=6.7 \mathrm{~Hz}, 3 \mathrm{H}), 0.87(\mathrm{t}, J=6.9 \mathrm{~Hz}, 3 \mathrm{H}) ;{ }^{13} \mathrm{C} \mathrm{NMR}\left(101 \mathrm{MHz}, \mathrm{CDCl}_{3}\right) \delta 139.3,128.6,83.2$, 75.7, 69.4, 39.1, 38.2, 36.3, 22.1, 20.5, 20.4, 14.5, 14.1; IR (neat) 3420 (br), 3312, 2949, 2361, 1456, $989 \mathrm{~cm}^{-1}$; EIMS m/z 163 (29), 149 (36), 105 (100), 77 (38), 69 (34); HREIMS calcd for 
$\mathrm{C}_{8} \mathrm{H}_{15} \mathrm{O}\left(\mathrm{M}^{+}-\mathrm{HC} \equiv \mathrm{CCH}_{2}\left(\mathrm{CH}_{3}\right) \mathrm{CH} \cdot\right)$ 127.1123, found 127.1119; optical rotation $[\alpha]_{\mathrm{D}}{ }^{27}+41^{\circ}(c$ $\left.1.0, \mathrm{CH}_{2} \mathrm{Cl}_{2}\right)$.

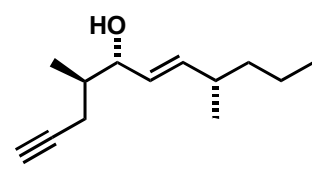

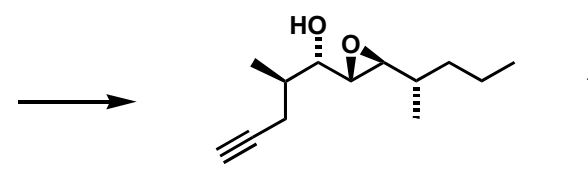

85

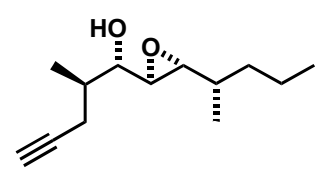

84

To a solution of the alkene $(272 \mathrm{mg}, 1.39 \mathrm{mmol})$ in $\mathrm{CH}_{2} \mathrm{Cl}_{2}(11 \mathrm{~mL})$ at $-10^{\circ} \mathrm{C}$ was added $\mathrm{VO}(\mathrm{acac})_{2}(26 \mathrm{mg}, 0.098 \mathrm{mmol})$ and tert-butyl hydroperoxide ( $840 \mu \mathrm{L}, 5-6 \mathrm{M}$ in decane, 4.2-5.0 mmol). The reaction mixture was stirred at $-10^{\circ} \mathrm{C}$ for $6 \mathrm{~h}$ and quenched with saturated $\mathrm{Na}_{2} \mathrm{SO}_{3}$. After stirring for $15 \mathrm{~min}$, the reaction mixture was diluted with ether and water. The aqueous phase was extracted with ether $(3 \mathrm{x})$ and the combined organic extracts were washed with brine (1 x), dried over $\mathrm{MgSO}_{4}$, and concentrated. Purification by flash column chromatography on silica gel (5\% to $7.5 \%$ to $10 \%$ to $15 \%$ to $20 \%$ EtOAc in petroleum ether) gave a mixture of epoxides 85 (231 mg, 78\%) and 84 (45 mg, 15\%) as colorless oils. Data for 85: $\mathrm{R}_{f}=0.44(20 \%$ EtOAc in petroleum ether); ${ }^{1} \mathrm{H}$ NMR $\left(400 \mathrm{MHz}, \mathrm{CDCl}_{3}\right) \delta 3.92(\mathrm{t}, J=3.5 \mathrm{~Hz}, 1 \mathrm{H}), 2.85(\mathrm{dd}, J=$ 6.9, $1.8 \mathrm{~Hz}, 1 \mathrm{H}$ ), 2.82 (t, $J=2.9 \mathrm{~Hz}, 1 \mathrm{H}$ ), 2.39 (ddd, $J=16.8,6.9,2.6 \mathrm{~Hz}, 1 \mathrm{H}$ ), 2.23 (ddd, $J=$ $16.8,7.2,2.8 \mathrm{~Hz}, 1 \mathrm{H}), 2.00(\mathrm{dd}, J=2.6,2.1 \mathrm{~Hz}, 1 \mathrm{H}), 1.94(\mathrm{~m}, 1 \mathrm{H}), 1.54-1.19(\mathrm{~m}, 6 \mathrm{H}), 1.07$ (d, $J$ $=6.9 \mathrm{~Hz}, 3 \mathrm{H}), 0.95(\mathrm{~d}, J=6.9 \mathrm{~Hz}, 3 \mathrm{H}), 0.91(\mathrm{t}, J=7.2 \mathrm{~Hz}, 3 \mathrm{H}) ;{ }^{13} \mathrm{C} \mathrm{NMR}\left(101 \mathrm{MHz}, \mathrm{CDCl}_{3}\right) \delta$ 82.8, 70.3, 67.9, 59.8, 58.2, 36.7, 35.7, 35.2, 22.8, 20.0, 15.9, 14.2, 14.0; IR (neat) 3466 (br), $3312,2959,2361,1460 \mathrm{~cm}^{-1}$; CIMS $m / z 211.2[\mathrm{M}+\mathrm{H}]^{+}$; optical rotation $[\alpha]_{\mathrm{D}}^{26}+2.0^{\circ}(c 0.25$, $\mathrm{CH}_{2} \mathrm{Cl}_{2}$ ); Anal. Calcd for $\mathrm{C}_{13} \mathrm{H}_{22} \mathrm{O}_{2}: \mathrm{C}, 74.24 ; \mathrm{H}, 10.54$. Found: $\mathrm{C}, 74.24 ; \mathrm{H}, 10.68$. Data for 84 : $\mathrm{R}_{f}=0.39\left(20 \%\right.$ EtOAc in petroleum ether); ${ }^{1} \mathrm{H}$ NMR $\left(400 \mathrm{MHz}, \mathrm{CDCl}_{3}\right) \delta 3.64(\mathrm{t}, J=4.4 \mathrm{~Hz}$, 1H), 2.91 (dd, $J=4.1,2.4 \mathrm{~Hz}, 1 \mathrm{H}), 2.75(\mathrm{dd}, J=6.9,2.3 \mathrm{~Hz}, 1 \mathrm{H}$ ), 2.37 (ddd, $J=16.8,6.9,2.6$ Hz, 1H), 2.24 (ddd, $J=16.8,6.6,2.4 \mathrm{~Hz}, 1 \mathrm{H}), 2.00$ (t, $J=2.4 \mathrm{~Hz}, 1 \mathrm{H}), 1.93(\mathrm{~m}, 1 \mathrm{H}), 1.43-1.20$ (m, 6H), $1.09(\mathrm{~d}, J=6.9 \mathrm{~Hz}, 3 \mathrm{H}), 1.01(\mathrm{~d}, J=6.4 \mathrm{~Hz}, 3 \mathrm{H}), 0.90(\mathrm{t}, J=6.9 \mathrm{~Hz}, 3 \mathrm{H}) ;{ }^{13} \mathrm{C}$ NMR $\left(101 \mathrm{MHz}, \mathrm{CDCl}_{3}\right) \delta 82.7,72.1,69.7,61.0,60.1,37.1,35.5,35.1,22.6,20.2,16.8,14.2,14.1 ; \mathrm{IR}$ (neat) 3464 (br), 3310, 2951, 2353, 1462, $902 \mathrm{~cm}^{-1}$; CIMS m/z $211.2[\mathrm{M}+\mathrm{H}]^{+}$; optical rotation $[\alpha]_{\mathrm{D}}{ }^{27}+39^{\circ}\left(c 0.50, \mathrm{CH}_{2} \mathrm{Cl}_{2}\right)$; Anal. Calcd for $\mathrm{C}_{13} \mathrm{H}_{22} \mathrm{O}_{2}$ : C, 74.24; H, 10.54. Found: C, 73.99; $\mathrm{H}$, 10.44 . 

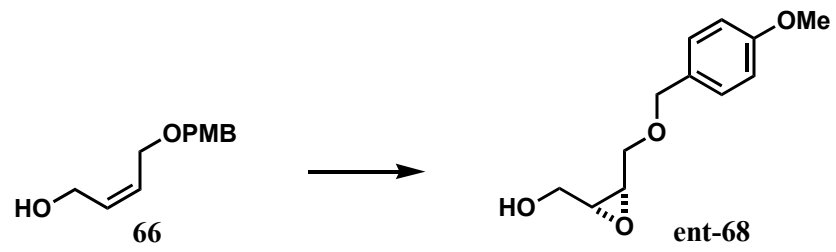

To a suspension of activated $3 \AA$ powdered molecular sieves $(19 \mathrm{~g})$ in $\mathrm{CH}_{2} \mathrm{Cl}_{2}(150 \mathrm{~mL})$ was added a solution of freshly distilled (-)-diethyl tartrate $(9.5 \mathrm{~mL}, 11 \mathrm{~g}, 56 \mathrm{mmol})$ in $\mathrm{CH}_{2} \mathrm{Cl}_{2}$ $(25 \mathrm{~mL})$. The solution was cooled to $-30^{\circ} \mathrm{C}$ and distilled $\mathrm{Ti}(\mathrm{O} i-\mathrm{Pr})_{4}(13.5 \mathrm{~mL}, 13.0 \mathrm{~g}, 46 \mathrm{mmol})$ and tert-butyl hydroperoxide ( $93 \mathrm{~mL}, 5-6 \mathrm{M}$ in decane, 465-558 mmol, solution dried for $20 \mathrm{~min}$ over activated $4 \AA$ molecular sieves before addition) were added. The solution was stirred at $30^{\circ} \mathrm{C}$ for $30 \mathrm{~min}$, and a solution of alcohol $66(19.250 \mathrm{~g}, 92.4 \mathrm{mmol})$ in $\mathrm{CH}_{2} \mathrm{Cl}_{2}(100 \mathrm{~mL}$, solution dried for $20 \mathrm{~min}$ over activated $4 \AA$ molecular sieves before addition) at $-30^{\circ} \mathrm{C}$ was added. The reaction mixture was maintained without stirring at $-20^{\circ} \mathrm{C}$ for $48 \mathrm{~h}$, and quenched by slow addition to a solution of $\mathrm{FeSO}_{4} \cdot 7 \mathrm{H}_{2} \mathrm{O}(153 \mathrm{~g})$ and tartaric acid $(96 \mathrm{~g})$ in water $(500 \mathrm{~mL})$ at $0^{\circ} \mathrm{C}$. The mixture was stirred for $15 \mathrm{~min}$ and extracted with ether $(3 \mathrm{x})$. The combined extracts were cooled to $0^{\circ} \mathrm{C}, 30 \%$ aqueous $\mathrm{NaOH}(100 \mathrm{~mL})$ was added, stirred for $1 \mathrm{~h}$, and diluted with water. The aqueous phase was extracted with ether $(3 \mathrm{x})$ and the combined organic extracts were washed with brine $(1 \mathrm{x})$, dried over $\mathrm{MgSO}_{4}$, and concentrated. Purification by crystallization from a mixture of $\mathrm{CH}_{2} \mathrm{Cl}_{2}$ and petroleum ether followed by filtration of an EtOAc solution through a pad of silica gel (washed with $10 \%$ to $50 \%$ EtOAc in petroleum ether) gave epoxide ent-68 $(15.146 \mathrm{~g}, 73 \%)$ as a low melting white solid that matched the spectroscopic data for $\mathbf{6 8}$ : optical rotation $[\alpha]_{\mathrm{D}}^{25}+16^{\circ}\left(c 2.15, \mathrm{CH}_{2} \mathrm{Cl}_{2}\right)$.
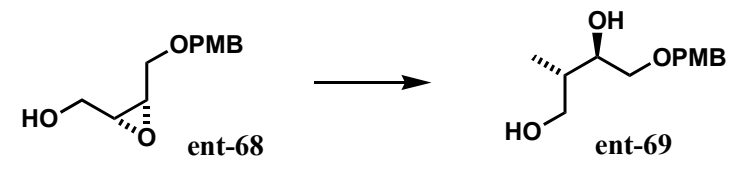

To a suspension of $\mathrm{CuCN}(5.645 \mathrm{~g}, 63.0 \mathrm{mmol})$ in ether $(60 \mathrm{~mL})$ at $-40^{\circ} \mathrm{C}$ was added $\mathrm{MeLi} \cdot \mathrm{LiBr}(80 \mathrm{~mL}, 1.5 \mathrm{M}$ in ether, $120 \mathrm{mmol})$. The solution was warmed from $-40^{\circ} \mathrm{C}$ to $-20^{\circ} \mathrm{C}$ over $1 \mathrm{~h}$, cooled to $-50^{\circ} \mathrm{C}$, and a solution of epoxide ent-68 (4.030 g, $\left.18.0 \mathrm{mmol}\right)$ in ether (20 $\mathrm{mL}$ ) was added via cannula. The reaction mixture was warmed from $-50^{\circ} \mathrm{C}$ to $-15^{\circ} \mathrm{C}$ over $1 \mathrm{~h}$, quenched with $\mathrm{pH} 9$ saturated $\mathrm{NH}_{4} \mathrm{Cl} /$ concentrated $\mathrm{NH}_{4} \mathrm{OH}$, warmed to room temperature, and stirred for several hours until all the solids dissolved. The aqueous phase was extracted with EtOAc $(8 \mathrm{x})$ and the combined organic extracts were washed with brine $(1 \mathrm{x})$, dried over $\mathrm{MgSO}_{4}$, 
and concentrated to give a mixture of ent-69 and the 1,2-diol which was used in the next step without purification. To a solution of alcohol ent-69, prepared in the previous step, and the 1,2diol in THF $(60 \mathrm{~mL})$ and water $(6 \mathrm{~mL})$ at $0^{\circ} \mathrm{C}$ was added $\mathrm{NaIO}_{4}(4.004 \mathrm{~g}, 18.7 \mathrm{mmol})$. The reaction mixture was warmed to room temperature, stirred for $1.5 \mathrm{~h}$, diluted with $\mathrm{CH}_{2} \mathrm{Cl}_{2}(200$ $\mathrm{mL}$ ), filtered through a glass frit, washed with brine, dried over $\mathrm{MgSO}_{4}$, and concentrated. Purification by flash column chromatography on silica gel (50\% to $75 \%$ to $100 \%$ EtOAc in petroleum ether) gave 1,3-diol ent-69 (2.91 g, 67\%) as a colorless oil that matched the spectroscopic data for 69.

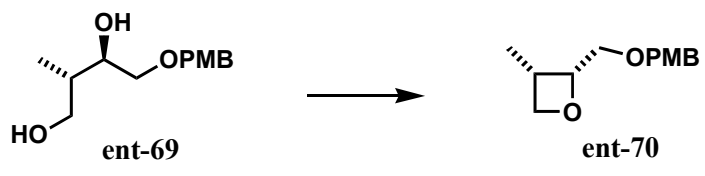

To a solution of diol ent-69 $(6.437 \mathrm{~g}, 26.8 \mathrm{mmol})$ in pyridine $(125 \mathrm{~mL})$ at $0^{\circ} \mathrm{C}$ was added $\mathrm{TsCl}(5.2 \mathrm{~g}, 27 \mathrm{mmol})$. The reaction mixture was stirred at $0^{\circ} \mathrm{C}$ for $2 \mathrm{~d}$, partially concentrated, and diluted with $1 \mathrm{M} \mathrm{HCl}$ and ether. The aqueous phase was extracted with ether $(4 \mathrm{x})$ and the combined organic extracts were washed with brine $(1 \mathrm{x})$, dried over $\mathrm{MgSO}_{4}$, and concentrated to give the tosylate which was used in the next step without purification. To a suspension of $\mathrm{NaH}$ ( $2.5 \mathrm{~g}, 60 \%$ dispersion in mineral oil, $63 \mathrm{mmol})$ in THF $(10 \mathrm{~mL})$ at room temperature was added a solution of the tosylate, prepared in the previous step, in THF $(55 \mathrm{~mL})$. The reaction mixture was stirred at room temperature for $10 \mathrm{~h}$, quenched with water, and diluted with ether and water. The aqueous phase was extracted with ether $(5 \mathrm{x})$ and the combined organic extracts were washed with brine $(1 \mathrm{x})$, dried over $\mathrm{MgSO}_{4}$, and concentrated. Purification by flash column chromatography on silica gel (20\% to $30 \%$ to $40 \%$ EtOAc in petroleum ether) gave ether ent-70 $(4.22 \mathrm{~g}, 69 \%)$ as a colorless oil that matched the spectroscopic data for $\mathbf{7 0}$.
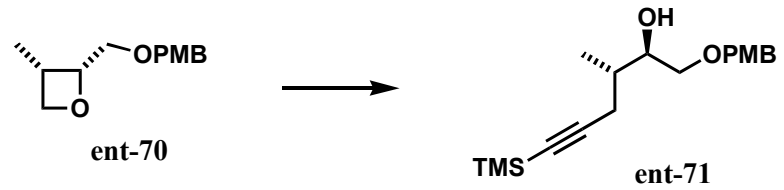

To a solution of (trimethylsilyl)acetylene $(12.4 \mathrm{~mL}, 8.62 \mathrm{~g}, 87.7 \mathrm{mmol})$ in THF (125 mL) at $-78^{\circ} \mathrm{C}$ was added $n$-BuLi $(62 \mathrm{~mL}, 1.3 \mathrm{M}$ in hexanes, $81 \mathrm{mmol})$. The solution was warmed to room temperature, cooled to $-78^{\circ} \mathrm{C}$, and $\mathrm{BF}_{3} \cdot \mathrm{Et}_{2} \mathrm{O}(10.3 \mathrm{~mL}, 11.4 \mathrm{~g}, 80.6 \mathrm{mmol})$ was added. After $10 \mathrm{~min}$, a solution of oxetane ent-70 (6.026 g, $26.4 \mathrm{mmol})$ in THF (20 mL) was added via 
cannula. The reaction mixture was stirred at $-78^{\circ} \mathrm{C}$ for $45 \mathrm{~min}$, quenched with saturated $\mathrm{NH}_{4} \mathrm{Cl}$, warmed to room temperature, and diluted with ether and water. The aqueous phase was extracted with ether $(3 \mathrm{x})$ and the combined organic extracts were washed with brine $(1 \mathrm{x})$, dried over $\mathrm{MgSO}_{4}$, and concentrated. Purification by flash column chromatography on silica gel (15\% to $30 \%$ EtOAc in petroleum ether) gave alcohol ent-71 (7.284 g, 86\%) as a colorless oil that matched the spectroscopic data reported for 71: Anal. Calcd for $\mathrm{C}_{18} \mathrm{H}_{28} \mathrm{O}_{3} \mathrm{Si}$ : C, 74.24; H, 10.54 . Found: C, 74.16; H, 10.36 .
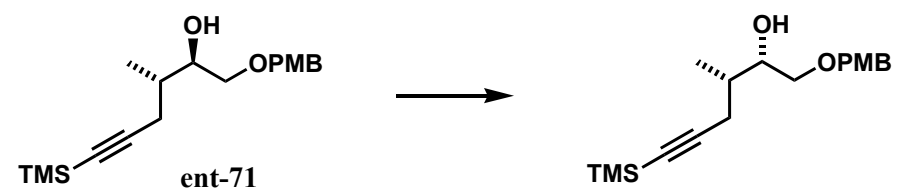

To a solution of alcohol ent-71 (3.410 g, $10.6 \mathrm{mmol})$ in DMF $(20 \mathrm{~mL})$ at room temperature was added a small amount of DMAP (spatula tip), imidazole (1.42 g, $20.9 \mathrm{mmol})$, and TBSCl $(2.11 \mathrm{~g}, 14.0 \mathrm{mmol})$. The reaction mixture was stirred at room temperature for $2 \mathrm{~h}$ and diluted with ether and water. The aqueous phase was extracted with ether $(4 \mathrm{x})$ and the combined organic extracts were washed with brine $(1 \mathrm{x})$, dried over $\mathrm{MgSO}_{4}$, and concentrated. Purification by flash column chromatography on silica gel (1\% to $2 \%$ to $4 \%$ EtOAc in petroleum ether) gave the ether $(3.612 \mathrm{~g}, 78 \%)$ as a colorless oil that matched the spectroscopic data reported for the corresponding enantiomer: optical rotation $[\alpha]^{26}+7.7^{\circ}\left(c 1.0, \mathrm{CH}_{2} \mathrm{Cl}_{2}\right)$.
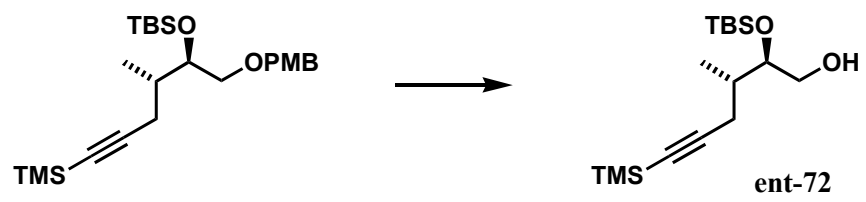

To a solution of the ether $(3.586 \mathrm{~g}, 8.25 \mathrm{mmol})$ in $\mathrm{CH}_{2} \mathrm{Cl}_{2}(60 \mathrm{~mL})$ and water $(20 \mathrm{~mL})$ at room temperature was added DDQ $(2.316 \mathrm{~g}, 10.2 \mathrm{mmol})$. After $1 \mathrm{~h}$ at room temperature, the reaction mixture was diluted with $\mathrm{CH}_{2} \mathrm{Cl}_{2}$, saturated $\mathrm{NaHCO}_{3}$, and water. The aqueous phase was extracted with $\mathrm{CH}_{2} \mathrm{Cl}_{2}(5 \mathrm{x})$ and the combined organic extracts were washed with brine (1 x), dried over $\mathrm{MgSO}_{4}$, and concentrated. Purification by flash column chromatography on silica gel (3\% to $6 \%$ to $10 \%$ EtOAc in petroleum ether) gave alcohol ent-72 $(2.522 \mathrm{~g}, 97 \%$ ) as a colorless oil that matched the spectroscopic data reported for 72: optical rotation $[\alpha]_{\mathrm{D}}^{25}+11^{\circ}(c 1.0$, $\mathrm{CH}_{2} \mathrm{Cl}_{2}$ ); Anal. Calcd for $\mathrm{C}_{16} \mathrm{H}_{34} \mathrm{O}_{2} \mathrm{Si}_{2}: \mathrm{C}, 61.08 ; \mathrm{H}, 10.89$. Found: C, 61.19; H, 10.81 . 


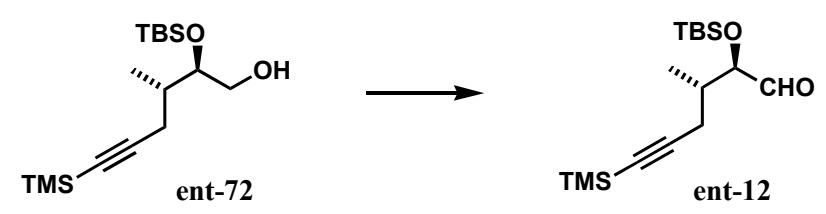

To a solution of alcohol ent-72 $(1.278 \mathrm{~g}, 4.06 \mathrm{mmol})$ in $\mathrm{CH}_{2} \mathrm{Cl}_{2}(33 \mathrm{~mL})$ at room temperature was added DMP $\left(9.4 \mathrm{~mL}, 15 \%\right.$ wt. in $\left.\mathrm{CH}_{2} \mathrm{Cl}_{2}, 4.5 \mathrm{mmol}\right)$. After $1.5 \mathrm{~h}$ at room temperature, the reaction mixture was quenched with saturated sodium thiosulfate and saturated $\mathrm{NaHCO}_{3}$, stirred for $15 \mathrm{~min}$, and diluted with water. The aqueous phase was extracted with $\mathrm{CH}_{2} \mathrm{Cl}_{2}(3 \mathrm{x})$ and the combined organic extracts were washed with brine $(1 \mathrm{x})$, dried over $\mathrm{MgSO}_{4}$, and concentrated. Purification by flash column chromatography on silica gel (3\% EtOAc in petroleum ether) gave aldehyde ent-12 $(926 \mathrm{mg}, 73 \%)$ as a colorless oil: $\mathrm{R}_{f}=0.41(5 \%$ EtOAc in petroleum ether); ${ }^{1} \mathrm{H}$ NMR $\left(500 \mathrm{MHz}, \mathrm{CDCl}_{3}\right) \delta 9.67(\mathrm{~d}, J=1.1 \mathrm{~Hz}, 1 \mathrm{H}), 4.21(\mathrm{dd}, J=$ 3.1, 1.1 Hz, 1H), 2.32-2.16 (m, 3H), $0.94(\mathrm{~s}, 9 \mathrm{H}), 0.91$ (d, $J=6.7 \mathrm{~Hz}, 3 \mathrm{H}), 0.14(\mathrm{~s}, 9 \mathrm{H}), 0.09$ (s, $6 \mathrm{H}) ;{ }^{13} \mathrm{C} \mathrm{NMR}\left(126 \mathrm{MHz}, \mathrm{CDCl}_{3}\right) \delta 204.9,105.2,86.7,78.8,36.2,25.8,23.9,18.2,13.7,0.0$, 4.5, -5.2; IR (neat) 2957, 2796, 2171, 1737, 1248, $840 \mathrm{~cm}^{-1}$; CIMS m/z $313[\mathrm{M}+\mathrm{H}]^{+}$; HREIMS calcd for $\mathrm{C}_{15} \mathrm{H}_{31} \mathrm{OSi}_{2}\left(\mathrm{M}^{+}\right.$- CHO) 283.1913, found 283.1918 .

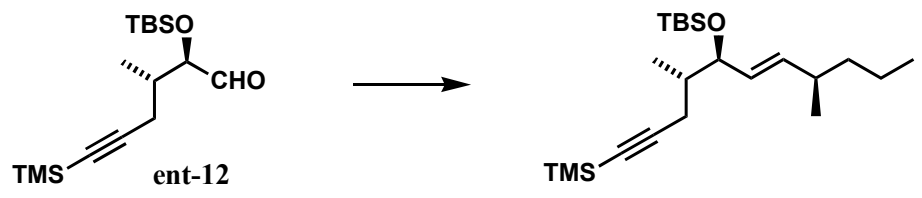

To $\mathrm{KN}(\mathrm{TMS})_{2}(7.5 \mathrm{~mL}, 0.46 \mathrm{M}$ in DME, $3.5 \mathrm{mmol})$ at $-78^{\circ} \mathrm{C}$ was added a solution of 13 (984 mg, $3.34 \mathrm{mmol})$ in $\mathrm{DME}(7 \mathrm{~mL})$ at $-78^{\circ} \mathrm{C}$. The solution was stirred at $-78^{\circ} \mathrm{C}$ for $1 \mathrm{~h}$ and a solution of aldehyde ent-12 $(781 \mathrm{mg}, 2.50 \mathrm{mmol})$ in DME $(7 \mathrm{~mL})$ at $-78^{\circ} \mathrm{C}$ was added via cannula. The reaction mixture was warmed from $-78^{\circ} \mathrm{C}$ to room temperature over $3 \mathrm{~h}$, stirred at room temperature for $10 \mathrm{~h}$, partially concentrated, and diluted with ether and water. The aqueous phase was extracted with ether $(5 \mathrm{x})$ and the combined organic extracts were washed with brine ( $1 \mathrm{x})$, dried over $\mathrm{MgSO}_{4}$, and concentrated. Purification by flash column chromatography on silica gel (1\% to $2 \%$ EtOAc in petroleum ether) gave the alkene ( $880 \mathrm{mg}, 93 \%)$ as a colorless oil: $\mathrm{R}_{f}=0.71$ (5\% EtOAc in petroleum ether); ${ }^{1} \mathrm{H}$ NMR $\left(400 \mathrm{MHz}, \mathrm{CDCl}_{3}\right) \delta 5.39(\mathrm{dd}, J=15.4,7.3$ $\mathrm{Hz}, 1 \mathrm{H}), 5.30(\mathrm{dd}, J=15.4,6.9 \mathrm{~Hz}, 1 \mathrm{H}), 4.04$ (dd, $J=6.9,4.9 \mathrm{~Hz}, 1 \mathrm{H}), 2.30$ (dd, $J=16.8,5.8$ $\mathrm{Hz}, 1 \mathrm{H}), 2.10$ (m, 1H), 2.05 (dd, $J=16.9,7.8 \mathrm{~Hz}, 1 \mathrm{H}), 1.68(\mathrm{~m}, 1 \mathrm{H}), 1.32-1.21(\mathrm{~m}, 4 \mathrm{H}), 0.963$ 
(d, $J=6.7 \mathrm{~Hz}, 3 \mathrm{H}), 0.957$ (d, $J=6.7 \mathrm{~Hz}, 3 \mathrm{H}), 0.89-0.86$ (m, 3H), 0.88 (s, 9H), 0.15 (s, 9H), 0.04 (s, 3H), 0.00 (s, 3H); ${ }^{13} \mathrm{C} \mathrm{NMR}\left(101 \mathrm{MHz}, \mathrm{CDCl}_{3}\right) \delta$ 137.7, 129.8, 106.9, 85.3, 76.0, 39.6, 39.2, 36.3, 25.9, 23.7, 20.6, 20.5, 18.2, 14.4, 14.1, 0.17, -4.0, -4.9; IR (neat) 2953, 2176, 1247, 1032, $842 \mathrm{~cm}^{-1}$; EIMS $m / z 147$ (57), 81 (50), 73 (97), 71 (69), 69 (100); HREIMS calcd for $\mathrm{C}_{18} \mathrm{H}_{35} \mathrm{OSi}_{2}$ $\left(\mathrm{M}^{+}\right.$- tert-Bu) 323.2226, found 323.2191; optical rotation $[\alpha]_{\mathrm{D}}{ }^{25}-23^{\circ}\left(c 1.0, \mathrm{CH}_{2} \mathrm{Cl}_{2}\right)$.

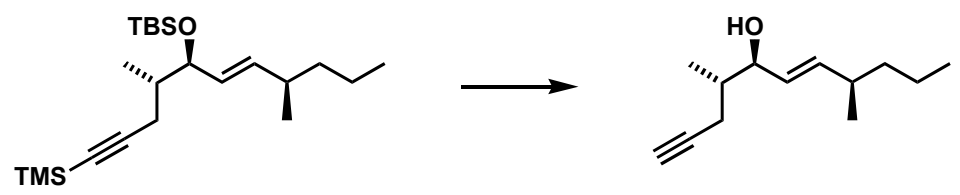

To a solution of the silyl ether $(859 \mathrm{mg}, 2.26 \mathrm{mmol})$ in THF $(5 \mathrm{~mL})$ at room temperature was added TBAF (5.0 mL, $1 \mathrm{M}$ in THF, $5.0 \mathrm{mmol})$. The reaction mixture was stirred at room temperature for $24 \mathrm{~h}$ and concentrated. Purification by flash column chromatography on silica gel (10\% to $20 \%$ to $40 \%$ EtOAc in petroleum ether) gave the alcohol (415 mg, $95 \%$ ) as a colorless oil: $\mathrm{R}_{f}=0.41\left(20 \%\right.$ EtOAc in petroleum ether); ${ }^{1} \mathrm{H}$ NMR $\left(400 \mathrm{MHz}, \mathrm{CDCl}_{3}\right) \delta 5.53$ (ddd, $J=15.4,7.8,0.9 \mathrm{~Hz}, 1 \mathrm{H}$ ), 5.40 (ddd, $J=15.4,7.0,0.9 \mathrm{~Hz}, 1 \mathrm{H}$ ), 4.06 (m, 1H), 2.32 (ddd, $J$ $=16.8,5.8,2.6 \mathrm{~Hz}, 1 \mathrm{H}), 2.13(\mathrm{~m}, 1 \mathrm{H}), 2.08(\mathrm{ddd}, J=16.8,7.6,2.8 \mathrm{~Hz}, 1 \mathrm{H}), 1.97$ (t, $J=2.6 \mathrm{~Hz}$, 1H), $1.80(\mathrm{~m}, 1 \mathrm{H}), 1.60(\mathrm{~d} \mathrm{br}, J=3.8 \mathrm{~Hz}, 1 \mathrm{H}), 1.30-1.23(\mathrm{~m}, 4 \mathrm{H}), 1.02(\mathrm{~d}, J=6.9 \mathrm{~Hz}, 3 \mathrm{H}), 0.97$ (d, $J=6.7 \mathrm{~Hz}, 3 \mathrm{H}), 0.87$ (t, $J=6.9 \mathrm{~Hz}, 3 \mathrm{H}) ;{ }^{13} \mathrm{C} \mathrm{NMR}\left(101 \mathrm{MHz}, \mathrm{CDCl}_{3}\right) \delta$ 139.3, 128.6, 83.2, 75.7, 69.4, 39.1, 38.2, 36.3, 22.1, 20.5, 20.4, 14.5, 14.1; IR (neat) 3420 (br), 3312, 2949, 2361, 1456, $989 \mathrm{~cm}^{-1}$; EIMS $m / z 163$ (29), 149 (36), 105 (100), 77 (38), 69 (34); HREIMS calcd for $\mathrm{C}_{8} \mathrm{H}_{15} \mathrm{O}\left(\mathrm{M}^{+}-\mathrm{HC} \equiv \mathrm{CCH}_{2}\left(\mathrm{CH}_{3}\right) \mathrm{CH} \cdot\right)$ 127.1123, found 127.1119; optical rotation $[\alpha]_{\mathrm{D}}{ }^{26}-39^{\circ}(c$ $1.0, \mathrm{CH}_{2} \mathrm{Cl}_{2}$ ).
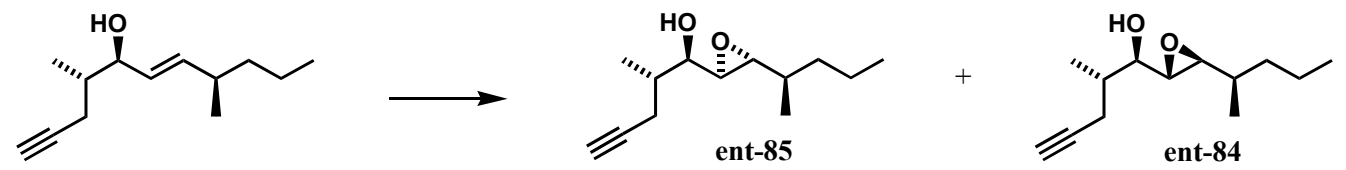

To a solution of the alkene $(415 \mathrm{mg}, 2.14 \mathrm{mmol})$ in $\mathrm{CH}_{2} \mathrm{Cl}_{2}(20 \mathrm{~mL})$ at $0^{\circ} \mathrm{C}$ was added MCPBA (649 mg, $68 \%$ pure, $2.6 \mathrm{mmol}$ ). The reaction mixture was stirred at $0^{\circ} \mathrm{C}$ for $5 \mathrm{~h}$ and quenched with saturated $\mathrm{Na}_{2} \mathrm{SO}_{3}$ and saturated $\mathrm{NaHCO}_{3}$. After stirring for 10 min, the reaction mixture was diluted with water. The aqueous phase was extracted with $\mathrm{CH}_{2} \mathrm{Cl}_{2}(5 \mathrm{x})$ and the combined organic extracts were washed with brine $(1 \mathrm{x})$, dried over $\mathrm{MgSO}_{4}$, and concentrated. 
Purification by flash column chromatography on silica gel (5\% to $10 \%$ to $20 \%$ EtOAc in petroleum ether) gave a mixture of epoxides ent-85 (122 mg, 27\%), ent-84 (258 mg, 57\%), and a mixture of ent-85 and ent-84 (48 mg, 11\%) as colorless oils. Data for ent-85: optical rotation $[\alpha]^{23}{ }_{D}+3.5^{\circ}\left(c 0.5, \mathrm{CH}_{2} \mathrm{Cl}_{2}\right)$; Anal. Calcd for $\mathrm{C}_{13} \mathrm{H}_{22} \mathrm{O}_{2}$ : C, 74.24; H, 10.54. Found: C, 74.24; $\mathrm{H}$, 10.68. Data for ent-84: optical rotation $[\alpha]_{\mathrm{D}}{ }^{24}-39^{\circ}\left(c\right.$ 1.0, $\left.\mathrm{CH}_{2} \mathrm{Cl}_{2}\right)$; Anal. Calcd for $\mathrm{C}_{13} \mathrm{H}_{22} \mathrm{O}_{2}: \mathrm{C}$, 74.24; H, 10.54. Found: C, 74.16; H, 10.36.
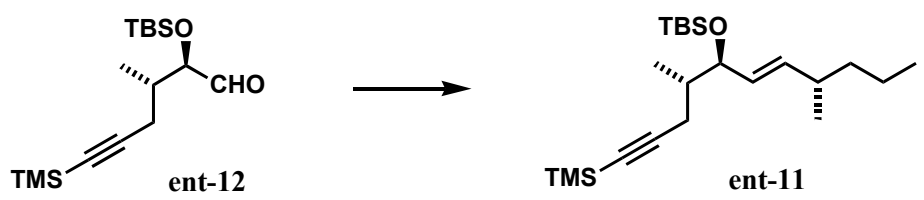

To a solution of $\mathrm{KN}(\mathrm{TMS})_{2}(8.0 \mathrm{~mL}, 0.47 \mathrm{M}$ in DME, $3.8 \mathrm{mmol})$ at $-78^{\circ} \mathrm{C}$ was added a solution of sulfone ent-13 $(1.106 \mathrm{~g}, 3.76 \mathrm{mmol})$ in DME $(8 \mathrm{~mL})$ at $-78^{\circ} \mathrm{C}$. The solution was stirred at $-78^{\circ} \mathrm{C}$ for $1 \mathrm{~h}$ and a solution of aldehyde ent-12 $(853 \mathrm{mg}, 2.73 \mathrm{mmol})$ in DME $(8 \mathrm{~mL})$ at $-78^{\circ} \mathrm{C}$ was added via cannula. The reaction mixture was warmed from $-78^{\circ} \mathrm{C}$ to room temperature over $2 \mathrm{~h}$, stirred at room temperature for $12 \mathrm{~h}$, partially concentrated, and diluted with ether and water. The aqueous phase was extracted with ether $(4 \mathrm{x})$ and the combined organic extracts were washed with brine $(1 \mathrm{x})$, dried over $\mathrm{MgSO}_{4}$, and concentrated. Purification by flash column chromatography on silica gel (1\% to $2 \%$ EtOAc in petroleum ether) gave alkene ent-11 (633 mg, 61\%) as a colorless oil that matched the spectroscopic data for 11.
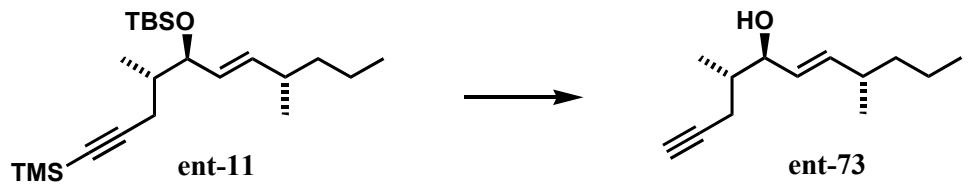

To a solution of silyl ether ent-11 $(633 \mathrm{mg}, 1.66 \mathrm{mmol})$ in THF $(3.7 \mathrm{~mL})$ at room temperature was added TBAF $(3.7 \mathrm{~mL}, 1 \mathrm{M}$ in THF, $3.7 \mathrm{mmol})$. The reaction mixture was stirred at room temperature for $24 \mathrm{~h}$ and concentrated. Purification by flash column chromatography on silica gel (10\% to $20 \%$ to $30 \%$ EtOAc in petroleum ether) gave alcohol ent-73 (319 mg, 99\%) as a colorless oil that matched the spectroscopic data for 73 : optical rotation $[\alpha]_{\mathrm{D}}^{25}-3.1^{\circ}(c 0.5$, $\mathrm{CH}_{2} \mathrm{Cl}_{2}$ ). 

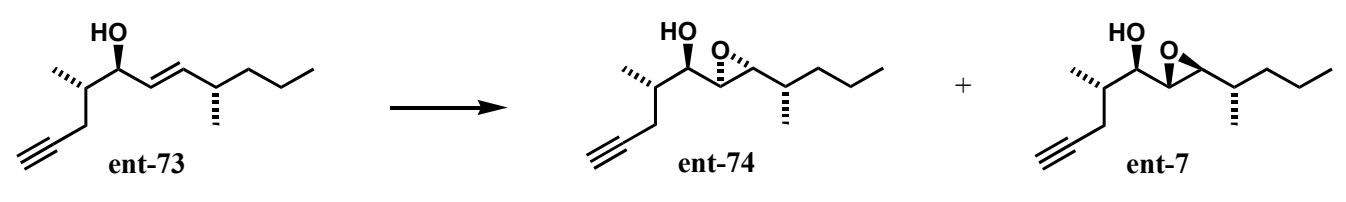

To a solution of alkene ent-73 $(319 \mathrm{mg}, 1.64 \mathrm{mmol})$ in $\mathrm{CH}_{2} \mathrm{Cl}_{2}(15 \mathrm{~mL})$ at $0^{\circ} \mathrm{C}$ was added MCPBA (542 mg, 68\% pure, $3.14 \mathrm{mmol})$. The reaction mixture was stirred at $0^{\circ} \mathrm{C}$ for $5 \mathrm{~h}$ and quenched with saturated $\mathrm{Na}_{2} \mathrm{SO}_{3}$ and saturated $\mathrm{NaHCO}_{3}$. After stirring for 15 min, the reaction mixture was diluted with water and ether. The aqueous phase was extracted with ether $(3 \mathrm{x})$ and the combined organic extracts were washed with brine ( $1 \mathrm{x})$, dried over $\mathrm{MgSO}_{4}$, and concentrated. Purification by flash column chromatography on silica gel (5\% to $10 \%$ to $20 \%$ EtOAc in petroleum ether) gave a mixture of epoxides ent-74 (136 mg, 39\%) and ent-7 (183 mg, $53 \%$ ) as colorless oils that matched the spectroscopic data reported for $\mathbf{7 4}$ and 7 . Data for ent74: optical rotation $[\alpha]^{25}{ }_{\mathrm{D}}+2.9^{\circ}\left(c 0.5, \mathrm{CH}_{2} \mathrm{Cl}_{2}\right)$. Data for ent-7: optical rotation $[\alpha]_{\mathrm{D}}{ }^{25}-27^{\circ}(c$ $0.5, \mathrm{CH}_{2} \mathrm{Cl}_{2}$ ).

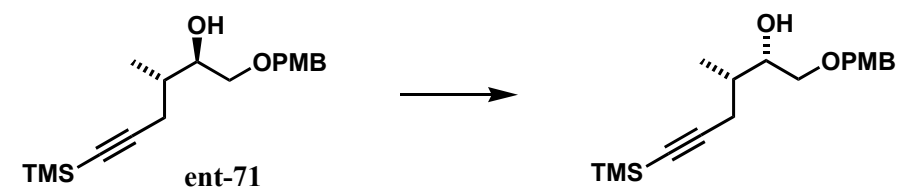

To a solution of alcohol ent-71 (107 $\mathrm{mg}, 0.33 \mathrm{mmol})$ in $\mathrm{PhH}(6.5 \mathrm{~mL})$ at room temperature was added triphenylphosphine ( $325 \mathrm{mg}, 1.24 \mathrm{mmol}), p$-nitrobenzoic acid (166 mg, $0.993 \mathrm{mmol})$, and DIAD ( $235 \mu \mathrm{L}, 241 \mathrm{mg}, 1.19 \mathrm{mmol})$. The reaction mixture was stirred at room temperature for $4 \mathrm{~h}$, concentrated, and filtered through silica gel (10\% to $15 \%$ to $20 \%$ EtOAc in petroleum ether) to give the ester which was used in the next step without purification. PH9-39: To a solution of the ester, prepared in the previous step, in $\mathrm{CH}_{2} \mathrm{Cl}_{2}(3 \mathrm{~mL})$ at $-78^{\circ} \mathrm{C}$ was added DIBAL ( $790 \mu \mathrm{L}, 1 \mathrm{M}$ in heptane, $0.79 \mathrm{mmol})$. The reaction mixture was stirred at $-78^{\circ} \mathrm{C}$ for 10 min, quenched with EtOAc, warmed to room temperature, diluted with aqueous sodium potassium tartrate, stirred for $15 \mathrm{~min}$, and diluted with ether and water. The aqueous phase was extracted with ether $(3 \mathrm{x})$ and the combined organic extracts were washed with brine $(1 \mathrm{x})$, dried over $\mathrm{MgSO}_{4}$, and concentrated. Purification by flash column chromatography on silica gel $(20 \%$ EtOAc in petroleum ether) gave the alcohol $(88 \mathrm{mg}, 82 \%)$ as a colorless oil: $\mathrm{R}_{f}=0.31(15 \%$ EtOAc in petroleum ether); ${ }^{1} \mathrm{H}$ NMR $\left(400 \mathrm{MHz}, \mathrm{CDCl}_{3}\right) \delta 7.26(\mathrm{~d}, J=8.9 \mathrm{~Hz}, 2 \mathrm{H}), 6.89(\mathrm{~d}, J=$ $8.7 \mathrm{~Hz}, 2 \mathrm{H}), 4.52-4.45$ (m, 2H), 3.81 (s, 3H), 3.63 (ddd, $J=7.5,7.5,2.9 \mathrm{~Hz}, 1 \mathrm{H}), 3.57$ (dd, $J=$ 
9.5, 3.1 Hz, 1H), 3.40 (dd, $J=9.3,7.3 \mathrm{~Hz}, 1 \mathrm{H}), 2.45$ (s br, 1H), 2.44 (dd, $J=16.9,4.6 \mathrm{~Hz}, 1 \mathrm{H})$, $2.29(\mathrm{dd}, J=17.1,7.5 \mathrm{~Hz}, 1 \mathrm{H}), 1.80(\mathrm{~m}, 1 \mathrm{H}), 0.98(\mathrm{~d}, J=6.9 \mathrm{~Hz}, 3 \mathrm{H}), 0.14(\mathrm{~s}, 9 \mathrm{H}),{ }^{13} \mathrm{C} \mathrm{NMR}$ $\left(101 \mathrm{MHz}, \mathrm{CDCl}_{3}\right) \delta 159.3,129.9,129.4,113.8,105.8,85.9,73.2,73.0,72.1,55.3,35.4,23.2$, 15.6, 0.12; optical rotation $[\alpha]_{\mathrm{D}}^{27}+1.4^{\mathrm{o}}\left(c 1.0, \mathrm{CH}_{2} \mathrm{Cl}_{2}\right)$.
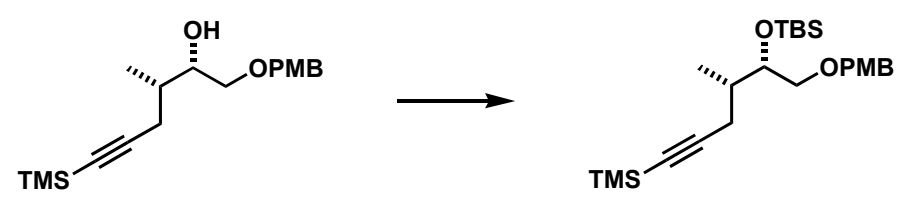

To a solution of the alcohol $(2.909 \mathrm{~g}, 9.08 \mathrm{mmol})$ in THF $(13 \mathrm{~mL})$ and DMF $(13 \mathrm{~mL})$ at room temperature was added a small amount of DMAP (spatula tip), imidazole (1.918 g, 28.2 $\mathrm{mmol}$ ), and $\mathrm{TBSCl}(1.986 \mathrm{~g}, 13.2 \mathrm{mmol})$. The reaction mixture was stirred at room temperature for $15 \mathrm{~h}$ and diluted with petroleum ether and water. The aqueous phase was extracted with petroleum ether $(3 \mathrm{x})$ and the combined organic extracts were washed with brine $(1 \mathrm{x})$, dried over $\mathrm{MgSO}_{4}$, and concentrated. Purification by flash column chromatography on silica gel (1\% to $2 \%$ to $5 \%$ EtOAc in petroleum ether) gave the ether $(3.483 \mathrm{~g}, 88 \%)$ as a colorless oil: $\mathrm{R}_{f}=0.38(5 \%$ EtOAc in petroleum ether); ${ }^{1} \mathrm{H}$ NMR $\left(500 \mathrm{MHz}, \mathrm{CDCl}_{3}\right) \delta 7.26(\mathrm{~d}, J=8.8 \mathrm{~Hz}, 2 \mathrm{H}), 6.87(\mathrm{~d}, J=$ $8.7 \mathrm{~Hz}, 2 \mathrm{H}), 4.44$ (s, 2H), 3.81 (s, 3H), 3.74 (q br, $J=5.2 \mathrm{~Hz}, 1 \mathrm{H}), 3.44$ (dd, $J=10.0,4.6 \mathrm{~Hz}$, $1 \mathrm{H}), 3.38(\mathrm{dd}, J=10.0,5.5 \mathrm{~Hz}, 1 \mathrm{H}), 2.31(\mathrm{dd}, J=16.9,5.3 \mathrm{~Hz}, 1 \mathrm{H}), 2.21(\mathrm{dd}, J=17.0,7.8 \mathrm{~Hz}$, 1H), $1.93(\mathrm{~m}, 1 \mathrm{H}), 0.99$ (d, $J=6.8 \mathrm{~Hz}, 3 \mathrm{H}), 0.88(\mathrm{~s}, 9 \mathrm{H}), 0.14(\mathrm{~s}, 9 \mathrm{H}), 0.06(\mathrm{~s}, 3 \mathrm{H}), 0.04(\mathrm{~s}, 3 \mathrm{H})$; ${ }^{13} \mathrm{C} \mathrm{NMR}\left(126 \mathrm{MHz}, \mathrm{CDCl}_{3}\right) \delta$ 159.1, 130.4, 129.2, 113.7, 106.7, 85.4, 74.2, 72.9, 72.5, 55.2, $36.1,25.9,22.4,18.2,16.1,0.2,-4.2,-4.9$; IR (neat) 2945,2174, 1612, 1249, 1092, 1038, $845 \mathrm{~cm}^{-}$ 1; EIMS m/z 283 (4), 121 (100), 147 (3); HREIMS calcd for $\mathrm{C}_{24} \mathrm{H}_{42} \mathrm{O}_{3} \mathrm{Si}_{2}$ 434.2673, found 434.2692; optical rotation $[\alpha]_{\mathrm{D}}{ }^{26}-5.3^{\circ}\left(c 1.0, \mathrm{CH}_{2} \mathrm{Cl}_{2}\right)$. Anal. Calcd for $\mathrm{C}_{24} \mathrm{H}_{42} \mathrm{O}_{3} \mathrm{Si}_{2}: \mathrm{C}, 61.08 ; \mathrm{H}$, 10.89. Found: C, 61.31; H, 10.67.
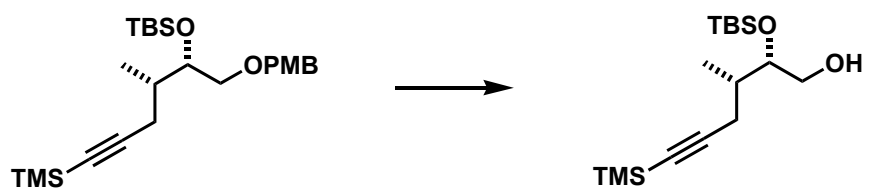

To a solution of the ether $(3.588 \mathrm{~g}, 8.25 \mathrm{mmol})$ in $\mathrm{CH}_{2} \mathrm{Cl}_{2}(60 \mathrm{~mL})$ and water $(20 \mathrm{~mL})$ at room temperature was added DDQ $(2.377 \mathrm{~g}, 10.5 \mathrm{mmol})$. After $2 \mathrm{~h}$ at room temperature, the reaction mixture was diluted with $\mathrm{CH}_{2} \mathrm{Cl}_{2}$, saturated $\mathrm{NaHCO}_{3}$, and water. The aqueous phase was 
extracted with $\mathrm{CH}_{2} \mathrm{Cl}_{2}(4 \mathrm{x})$ and the combined organic extracts were washed with brine $(1 \mathrm{x})$, dried over $\mathrm{MgSO}_{4}$, and concentrated. Purification by flash column chromatography on silica gel ( $5 \%$ to $7 \%$ to $12 \%$ EtOAc in petroleum ether) gave the alcohol $(2.577 \mathrm{~g}, 99 \%$ ) as a colorless oil: $\mathrm{R}_{f}=0.46\left(20 \%\right.$ EtOAc in petroleum ether); ${ }^{1} \mathrm{H}$ NMR $\left(400 \mathrm{MHz}, \mathrm{CDCl}_{3}\right) \delta 3.68-3.56(\mathrm{~m}, 3 \mathrm{H})$, $2.31(\mathrm{dd}, J=16.9,5.8 \mathrm{~Hz}, 1 \mathrm{H}), 2.23(\mathrm{dd}, J=16.9,6.4 \mathrm{~Hz}, 1 \mathrm{H}), 1.97$ (sept br, $J=6.6 \mathrm{~Hz}, 1 \mathrm{H}$ ), $1.84(\mathrm{dd}, J=7.2,5.5 \mathrm{~Hz}, 1 \mathrm{H}), 0.99$ (d, $J=6.9 \mathrm{~Hz}, 3 \mathrm{H}), 0.91$ (s, 9H), 0.14 (s, 9H), 0.11 (s, 3H), $0.10(\mathrm{~s}, 3 \mathrm{H}) ;{ }^{13} \mathrm{C} \mathrm{NMR}\left(101 \mathrm{MHz}, \mathrm{CDCl}_{3}\right) \delta$ 105.9, 86.0, 75.1, 63.7, 35.1, 25.9, 23.1, 18.1, 15.7, 0.1, -4.4, -4.7; IR (neat) 3447, 2954, 2165, 1249, 1047, $841 \mathrm{~cm}^{-1}$; CIMS m/z 315 (51) $[\mathrm{M}+\mathrm{H}]^{+}$, 183 (29), 147 (60); HREIMS calcd for $\mathrm{C}_{15} \mathrm{H}_{31} \mathrm{OSi}_{2}\left(\mathrm{M}^{+}-\mathrm{CH}_{2} \mathrm{OH}\right)$ 283.1913, found 283.1909; optical rotation $[\alpha]_{\mathrm{D}}{ }^{27}-21^{\mathrm{o}}\left(\mathrm{c} 1.0, \mathrm{CH}_{2} \mathrm{Cl}_{2}\right)$.

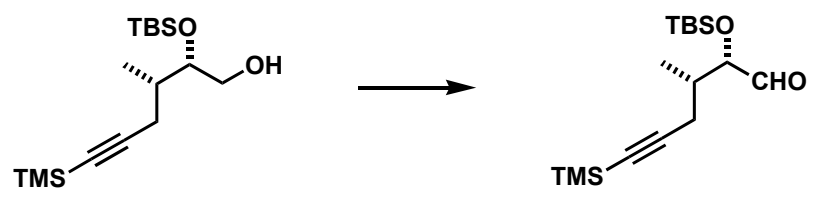

To a solution of the alcohol $(1.261 \mathrm{~g}, 4.01 \mathrm{mmol})$ in $\mathrm{CH}_{2} \mathrm{Cl}_{2}(33 \mathrm{~mL})$ at $0^{\circ} \mathrm{C}$ was added DMP (9.2 mL, $15 \%$ wt. in $\left.\mathrm{CH}_{2} \mathrm{Cl}_{2}, 4.4 \mathrm{mmol}\right)$. The reaction mixture was warmed to room temperature, stirred at room temperature for $1 \mathrm{~h}$, quenched with saturated sodium thiosulfate and saturated $\mathrm{NaHCO}_{3}$, stirred for $30 \mathrm{~min}$, and diluted with water and $\mathrm{CH}_{2} \mathrm{Cl}_{2}$. The aqueous phase was extracted with $\mathrm{CH}_{2} \mathrm{Cl}_{2}(3 \mathrm{x})$ and the combined organic extracts were washed with brine (1 $\mathrm{x}$ ), dried over $\mathrm{MgSO}_{4}$, and concentrated. Purification by flash column chromatography on silica gel (2.5\% EtOAc in petroleum ether) gave the aldehyde $(859 \mathrm{mg}, 69 \%)$ as a colorless oil: $\mathrm{R}_{f}=$ 0.48 (5\% EtOAc in petroleum ether); ${ }^{1} \mathrm{H} \mathrm{NMR}\left(500 \mathrm{MHz}, \mathrm{CDCl}_{3}\right) \delta 9.62(\mathrm{~d}, J=2.2 \mathrm{~Hz}, 1 \mathrm{H})$, $3.84(\mathrm{dd}, J=5.6,2.3 \mathrm{~Hz}, 1 \mathrm{H}), 2.33(\mathrm{dd}, J=16.9,6.5 \mathrm{~Hz}, 1 \mathrm{H}), 2.27$ (dd, $J=16.9,6.5 \mathrm{~Hz}, 1 \mathrm{H})$, 2.11 (sept br, $J=6.6 \mathrm{~Hz}, 1 \mathrm{H}), 1.03$ (d, $J=6.8 \mathrm{~Hz}, 3 \mathrm{H}), 0.92(\mathrm{~s}, 9 \mathrm{H}), 0.14(\mathrm{~s}, 9 \mathrm{H}), 0.08(\mathrm{~s}, 3 \mathrm{H})$, 0.07 (s, 3H); ${ }^{13} \mathrm{C}$ NMR (126 MHz, $\left.\mathrm{CDCl}_{3}\right) \delta$ 203.9, 105.2, 86.9, 80.2, 36.4, 25.7, 22.1, 18.1, 15.8, 0.0, -4.5, -5.1; IR (neat) 2959, 2850, 2180, 1737, 1252, $841 \mathrm{~cm}^{-1}$; CIMS m/z 313 (31) $[\mathrm{M}+\mathrm{H}]^{+}$, 283 (19), 181 (19), 147 (28); HREIMS calcd for $\mathrm{C}_{15} \mathrm{H}_{31} \mathrm{OSi}_{2}\left(\mathrm{M}^{+}\right.$- CHO) 283.1913, found 283.1917; optical rotation $[\alpha]_{\mathrm{D}}^{27}-21^{\mathrm{o}}\left(c 1.0, \mathrm{CH}_{2} \mathrm{Cl}_{2}\right)$. 


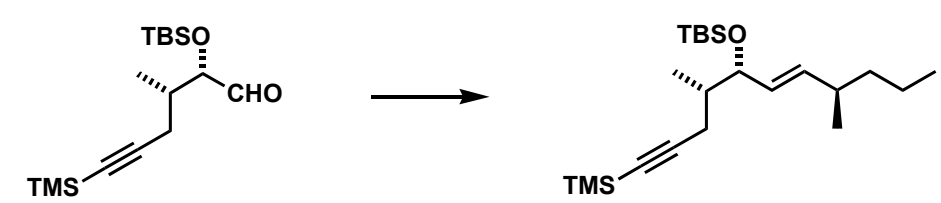

To $\mathrm{KN}(\mathrm{TMS})_{2}(7.10 \mathrm{~mL}, 0.47 \mathrm{M}$ in DME, $3.34 \mathrm{mmol})$ at $-78^{\circ} \mathrm{C}$ was added a solution of $13(982 \mathrm{mg}, 3.33 \mathrm{mmol})$ in DME $(7 \mathrm{~mL})$ at $-78^{\circ} \mathrm{C}$. The solution was stirred at $-78^{\circ} \mathrm{C}$ for $1 \mathrm{~h}$ and a solution of the aldehyde $(834 \mathrm{mg}, 2.67 \mathrm{mmol})$ in DME $(7 \mathrm{~mL})$ at $-78^{\circ} \mathrm{C}$ was added via cannula. The reaction mixture was warmed from $-78^{\circ} \mathrm{C}$ to room temperature over $3 \mathrm{~h}$, stirred at room temperature for $12 \mathrm{~h}$, partially concentrated, and diluted with petroleum ether and water. The aqueous phase was extracted with petroleum ether $(3 \mathrm{x})$ and the combined organic extracts were washed with brine $(1 \mathrm{x})$, dried over $\mathrm{MgSO}_{4}$, and concentrated. Purification by flash column chromatography on silica gel (1\% to $2 \%$ EtOAc in petroleum ether) gave the alkene $(834 \mathrm{mg}$, $82 \%)$ as a colorless oil: $\mathrm{R}_{f}=0.65\left(2.5 \%\right.$ EtOAc in petroleum ether); ${ }^{1} \mathrm{H}$ NMR $\left(400 \mathrm{MHz}, \mathrm{CDCl}_{3}\right)$ $\delta 5.42(\mathrm{dd}, J=15.6,7.6 \mathrm{~Hz}, 1 \mathrm{H}), 5.28$ (dd, $J=15.4,7.3 \mathrm{~Hz}, 1 \mathrm{H}), 3.93$ (dd, $J=6.9,6.9 \mathrm{~Hz}, 1 \mathrm{H})$, $2.28(\mathrm{dd}, J=16.9,5.5 \mathrm{~Hz}, 1 \mathrm{H}), 2.20(\mathrm{dd}, J=16.8,7.3 \mathrm{~Hz}, 1 \mathrm{H}), 2.12(\mathrm{~m}, 1 \mathrm{H}), 1.70$ (sept br, $J=$ $6.9 \mathrm{~Hz}, 1 \mathrm{H}), 1.32-1.22(\mathrm{~m}, 4 \mathrm{H}), 0.96(\mathrm{~d}, J=6.9 \mathrm{~Hz}, 3 \mathrm{H}), 0.91(\mathrm{~d}, J=6.9 \mathrm{~Hz}, 3 \mathrm{H}), 0.90-0.86(\mathrm{~m}$, $3 \mathrm{H}), 0.88(\mathrm{~s}, 9 \mathrm{H}), 0.15(\mathrm{~s}, 9 \mathrm{H}), 0.05(\mathrm{~s}, 3 \mathrm{H}), 0.01(\mathrm{~s}, 3 \mathrm{H}) ;{ }^{13} \mathrm{C} \mathrm{NMR}\left(101 \mathrm{MHz}, \mathrm{CDCl}_{3}\right) \delta 138.2$, 129.3, 106.6, 85.4, 76.6, 39.2, 39.1, 36.1, 25.9, 23.1, 20.6, 20.4, 18.2, 15.3, 14.2, 0.17, -4.0, -4.9; IR (neat) 2959, 2171, 1460, 1252, 1062, $840 \mathrm{~cm}^{-1}$; CIMS m/z 381 (16) [M + H] $]^{+}, 365$ (24), 323 (22), 249 (88), 241 (88), 175 (42), 147 (61); HREIMS calcd for $\mathrm{C}_{18} \mathrm{H}_{35} \mathrm{OSi}_{2}\left(\mathrm{M}^{+}\right.$- tert-butyl) 323.2226, found 323.2236; optical rotation $[\alpha]_{\mathrm{D}}{ }^{25}-2.3^{\circ}\left(c 1.0, \mathrm{CH}_{2} \mathrm{Cl}_{2}\right)$.

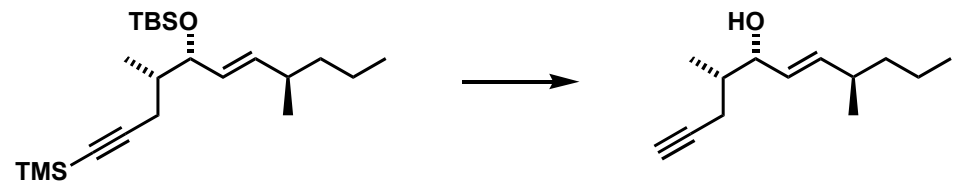

To a solution of the silyl ether $(834 \mathrm{mg}, 2.19 \mathrm{mmol})$ in THF $(5 \mathrm{~mL})$ at room temperature was added TBAF $(5.0 \mathrm{~mL}, 1 \mathrm{M}$ in THF, $5.0 \mathrm{mmol})$. The reaction mixture was stirred at room temperature for $24 \mathrm{~h}$, concentrated, and diluted with ether and water. The aqueous phase was extracted with ether $(3 \mathrm{x})$ and the combined organic extracts were washed with brine $(1 \mathrm{x})$, dried over $\mathrm{MgSO}_{4}$, and concentrated. Purification by flash column chromatography on silica gel (5\% to $10 \%$ to $20 \%$ EtOAc in petroleum ether) gave the alcohol (352 mg, 83\%) as a colorless oil: $\mathrm{R}_{f}$ $=0.65(2.5 \%$ EtOAc in petroleum ether $) ;{ }^{1} \mathrm{H}$ NMR $\left(500 \mathrm{MHz}, \mathrm{CDCl}_{3}\right) \delta 5.56(\mathrm{ddd}, J=15.5,7.7$, 
$0.9 \mathrm{~Hz}, 1 \mathrm{H}), 5.39$ (ddd, $J=15.4,7.4,1.0 \mathrm{~Hz}, 1 \mathrm{H}), 3.95$ (ddd, $J=7.2,7.2,3.5 \mathrm{~Hz}, 1 \mathrm{H}), 2.32$ (ddd, $J=16.7,5.0,2.7 \mathrm{~Hz}, 1 \mathrm{H}), 2.24(\mathrm{ddd}, J=16.7,7.2,2.7 \mathrm{~Hz}, 1 \mathrm{H}), 2.15(\mathrm{~m}, 1 \mathrm{H}), 1.97(\mathrm{t}, J=2.7 \mathrm{~Hz}$, 1H), 1.78 (ddd, $J=14.0,7.1,5.1 \mathrm{~Hz}, 1 \mathrm{H}), 1.57$ (d br, $J=3.5 \mathrm{~Hz}, 1 \mathrm{H}), 1.31-1.24$ (m, 4H), 0.974 $(\mathrm{d}, J=7.0 \mathrm{~Hz}, 3 \mathrm{H}), 0.972(\mathrm{~d}, J=6.7 \mathrm{~Hz}, 3 \mathrm{H}), 0.88(\mathrm{t}, J=7.0 \mathrm{~Hz}, 3 \mathrm{H}) ;{ }^{13} \mathrm{C} \mathrm{NMR}(126 \mathrm{MHz}$, $\left.\mathrm{CDCl}_{3}\right) \delta 139.7,128.7,83.1,76.1,69.4,39.0,38.0,36.1,21.8,20.5,20.4,15.4,14.1$; IR (neat) 3384, 3312, 2949, 1451, 1008, $971 \mathrm{~cm}^{-1}$; CIMS m/z 195 (5) [M + H] $]^{+}, 177$ (14), 137 (36), 109 (35); HREIMS calcd for $\mathrm{C}_{8} \mathrm{H}_{15} \mathrm{O}\left(\mathrm{M}^{+}-\mathrm{HC} \equiv \mathrm{CCH}_{2}\left(\mathrm{CH}_{3}\right) \mathrm{CH}\right)$ 127.1123, found 127.1128; optical rotation $[\alpha]_{\mathrm{D}}^{24}-7.3^{\circ}\left(c 1.0, \mathrm{CH}_{2} \mathrm{Cl}_{2}\right)$.
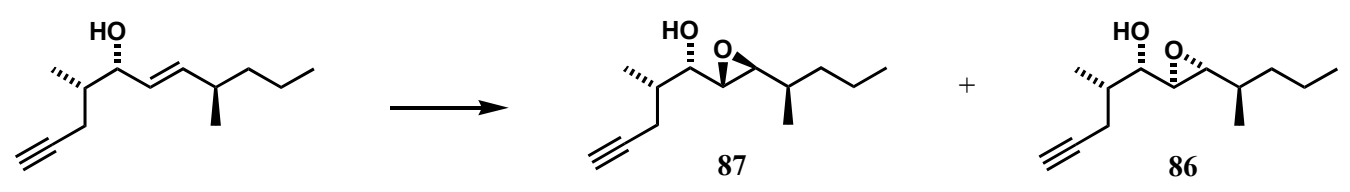

To a solution of the alkene $(352 \mathrm{mg}, 1.81 \mathrm{mmol})$ in $\mathrm{CH}_{2} \mathrm{Cl}_{2}(17 \mathrm{~mL})$ at $0^{\circ} \mathrm{C}$ was added MCPBA (562 mg, 68\% pure, $2.2 \mathrm{mmol}$ ). The reaction mixture was stirred at $0^{\circ} \mathrm{C}$ for $5 \mathrm{~h}$ and quenched with saturated $\mathrm{Na}_{2} \mathrm{SO}_{3}$ and saturated $\mathrm{NaHCO}_{3}$. After stirring for $10 \mathrm{~min}$, the reaction mixture was diluted with water. The aqueous phase was extracted with $\mathrm{CH}_{2} \mathrm{Cl}_{2}(4 \mathrm{x})$ and the combined organic extracts were washed with brine $(1 \mathrm{x})$, dried over $\mathrm{MgSO}_{4}$, and concentrated. Purification by flash column chromatography on silica gel ( $5 \%$ to $10 \%$ to $20 \%$ EtOAc in petroleum ether) gave a mixture of epoxides 87 (116 mg, 30\%), 86 (201 $\mathrm{mg}, 53 \%)$, and a mixture of 87 and 86 (54 mg, 14\%) as colorless oils. Data for 87: $\mathrm{R}_{f}=0.37$ (20\% EtOAc in petroleum ether); ${ }^{1} \mathrm{H} \mathrm{NMR}\left(400 \mathrm{MHz}, \mathrm{CDCl}_{3}\right) \delta 3.63(\mathrm{dd}, J=7.5,3.2,3.2 \mathrm{~Hz}, 1 \mathrm{H}), 2.92(\mathrm{dd}, J=$ 3.5, 2.4 Hz, 1H), 2.76 (dd, $J=7.0,2.4 \mathrm{~Hz}, 1 \mathrm{H}), 2.41$ (ddd, $J=16.8,4.6,2.7 \mathrm{~Hz}, 1 \mathrm{H}), 2.31$ (ddd, $J=16.7,7.3,2.7 \mathrm{~Hz}, 1 \mathrm{H}), 2.13(\mathrm{~d}, J=2.4 \mathrm{~Hz}, 1 \mathrm{H}), 1.98(\mathrm{t}, J=2.6 \mathrm{~Hz}, 1 \mathrm{H}), 1.83(\mathrm{~m}, 1 \mathrm{H}), 1.40-$ $1.20(\mathrm{~m}, 5 \mathrm{H}), 1.11(\mathrm{~d}, J=6.9 \mathrm{~Hz}, 3 \mathrm{H}), 1.00(\mathrm{~d}, J=6.4 \mathrm{~Hz}, 3 \mathrm{H}), 0.89(\mathrm{t}, J=6.9 \mathrm{~Hz}, 3 \mathrm{H}) ;{ }^{13} \mathrm{C}$ NMR (101 MHz, $\left.\mathrm{CDCl}_{3}\right) \delta 82.4,71.3,69.8,59.5,59.0,36.3,35.5,34.9,22.0,20.1,16.8,15.2$, 14.2; IR (neat) 3457, 3303, 2958, 1460, $903 \mathrm{~cm}^{-1}$; CIMS m/z $211(8)[\mathrm{M}+\mathrm{H}]^{+}, 193$ (53), 153 (27), 127 (65), 109 (51); HREIMS calcd for $\mathrm{C}_{8} \mathrm{H}_{15} \mathrm{O}_{2}\left(\mathrm{M}^{+}-\mathrm{HC} \equiv \mathrm{CCH}_{2}\left(\mathrm{CH}_{3}\right) \mathrm{CH}\right)$ 143.1072, found 143.1076; optical rotation $[\alpha]_{\mathrm{D}}^{26}-6.9^{\circ}\left(c 0.50, \mathrm{CH}_{2} \mathrm{Cl}_{2}\right)$. Data for 86: $\mathrm{R}_{f}=0.30(20 \%$ EtOAc in petroleum ether); ${ }^{1} \mathrm{H}$ NMR $\left(400 \mathrm{MHz} \mathrm{CDCl}_{3}\right) \delta 3.25$ (ddd, $\left.J=7.9,5.3,5.3 \mathrm{~Hz}, 1 \mathrm{H}\right)$, $2.80(\mathrm{dd}, J=5.8,2.3 \mathrm{~Hz}, 1 \mathrm{H}), 2.73(\mathrm{dd}, J=7.3,2.4 \mathrm{~Hz}, 1 \mathrm{H}), 2.47(\mathrm{~d} \mathrm{br}, J=5.2 \mathrm{~Hz}, 1 \mathrm{H}), 2.39$ $(\mathrm{ddd}, J=16.8,4.7,2.6 \mathrm{~Hz}, 1 \mathrm{H}), 2.32(\mathrm{ddd}, J=16.8,6.9,2.6 \mathrm{~Hz}, 1 \mathrm{H}), 1.95(\mathrm{t}, J=2.8 \mathrm{~Hz}, 1 \mathrm{H})$, 
$1.88(\mathrm{~m}, 1 \mathrm{H}), 1.52-1.19(\mathrm{~m}, 5 \mathrm{H}), 1.06(\mathrm{~d}, J=6.9 \mathrm{~Hz}, 3 \mathrm{H}), 0.92(\mathrm{~d}, J=6.9 \mathrm{~Hz}, 3 \mathrm{H}), 0.88(\mathrm{t}, J=$ $7.0 \mathrm{~Hz}, 3 \mathrm{H}) ;{ }^{13} \mathrm{C} \mathrm{NMR}\left(101 \mathrm{MHz}, \mathrm{CDCl}_{3}\right) \delta 82.3,74.3,69.7,62.3,59.1,36.6,36.2,35.1,21.8$, 19.9, 15.7, 15.4, 14.2; IR (neat) 3457, 3303, 2945, 1456, $908 \mathrm{~cm}^{-1}$; CIMS m/z 211 (13) $[\mathrm{M}+\mathrm{H}]^{+}$, 193 (75), 153 (21), 135 (29), 127 (26), 109 (61); HREIMS calcd for $\mathrm{C}_{8} \mathrm{H}_{15} \mathrm{O}_{2}\left(\mathrm{M}^{+}\right.$-

$\left.\mathrm{HC} \equiv \mathrm{CCH}_{2}\left(\mathrm{CH}_{3}\right) \mathrm{CH}\right) 143.1072$, found 143.1060 ; optical rotation $[\alpha]_{\mathrm{D}}{ }^{27}+24^{\circ}\left(c 0.50, \mathrm{CH}_{2} \mathrm{Cl}_{2}\right)$; Anal. Calcd for $\mathrm{C}_{13} \mathrm{H}_{22} \mathrm{O}_{2}$ : C, 74.24; H, 10.54. Found: C, 74.50; H, 10.36. 